


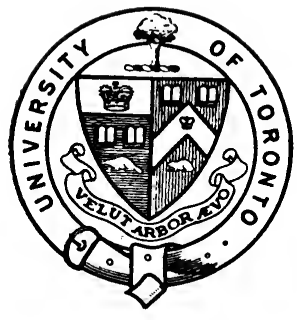

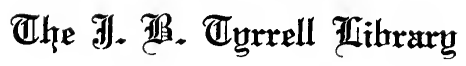

gequareathed to the

杰niwersity af Taranto Tlithrary

by

Joseph 绝urx Tyrrell

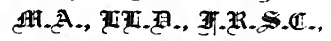

3.

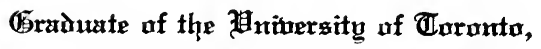
and emixtent Canadian geologist, explorer, ant setholar 
-

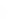


Digitized by the Internet Archive in 2007 with funding from Microsoft Corporation 


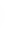

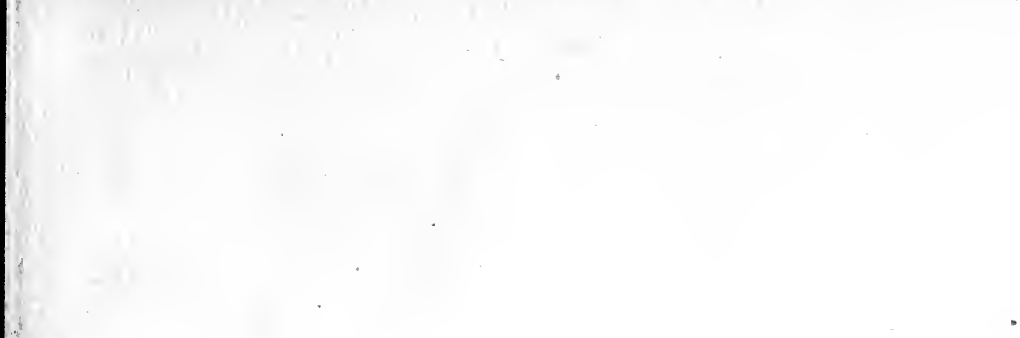

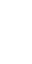


. 


\section{JOURNAL OF A FUR-TRADING EXPEDITION ON THE UPPER MISSOURI I812-1813}





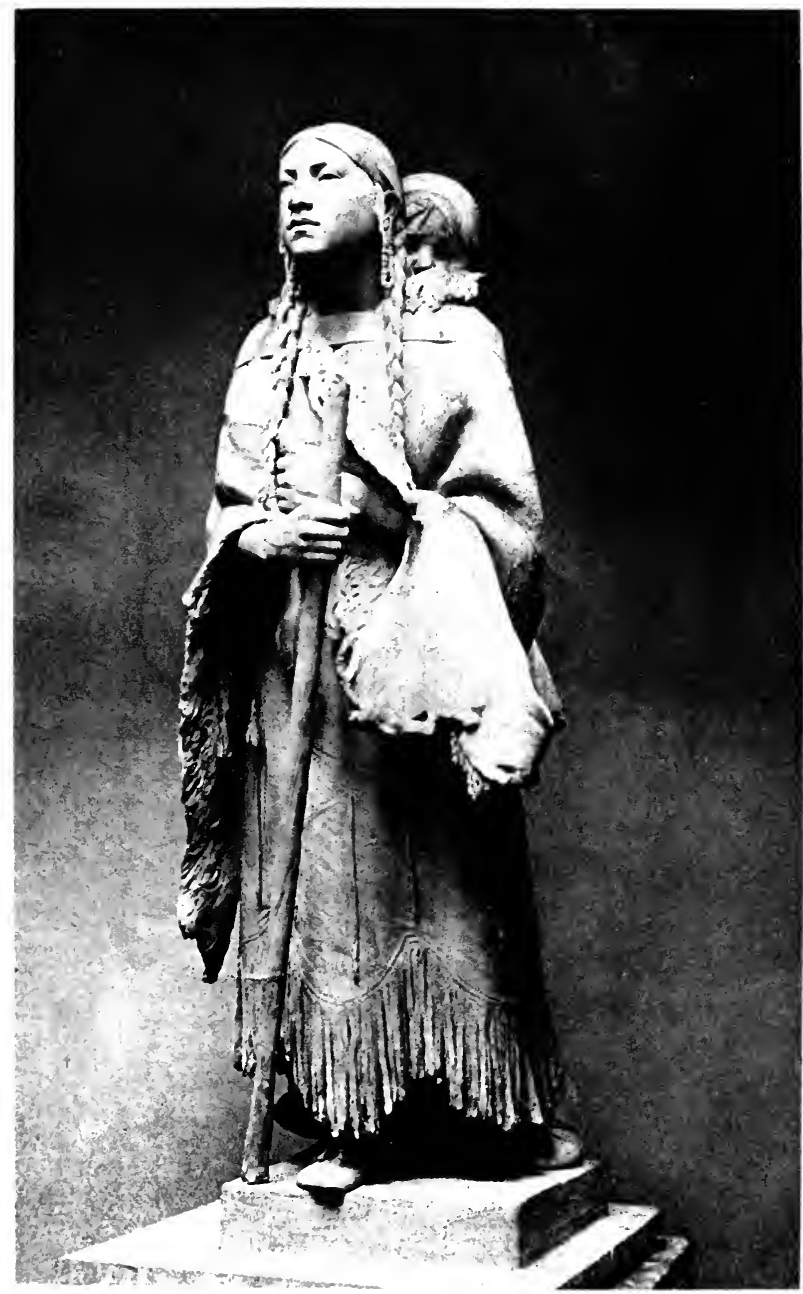

Serfictherreer 


\title{
JOURNAL OF A FUR-TRADING EXPEDITION ON THE UPPER MISSOURI 1812-1813
}

\author{
By JOHN C. LUTTIG \\ CLERK OF THE MISSOURI FUR COMPANY
}

Edited by

STELLA M. DRUMM

ST. LOUIS

MISSOURI HISTORICAL SOCIETY

1920 
Of this book, three hundred and sixty-five copies

have been printed from type, of

which this copy is

No. 6.3

Missouri Historical Socirty

Copyright, 1920,

By Missouri Historical Society

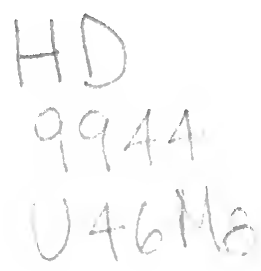

$\frac{6 \operatorname{con} 2 \sin 5}{6.1257}$

Franklin Hudson Press

Kansas City, Mo. 
TO

WILLIAM KEENEY BIXBY,

A Tribute

of Appreciation 


\section{CONTENTS}

Introduction $\ldots \ldots \ldots \ldots \ldots \ldots \ldots \ldots \ldots \ldots \ldots \ldots \ldots \ldots \ldots \ldots$

Journal ............................... 27

\section{ILLUSTRATIONS}

Sakakawea-From a photograph supplied by the sculptor,

Bruno Louis Zimm .......................... Frontispiece First page of Journal.................... Facing page 27

Manuel Lisa.......................... Facing page 45

Charles Sanguinet, fils.................... Facing page 76

Fort Manuel-From a drawing by W. O. Bassford....Facing page 95

Court Minute of Guardianship................ Facing page 106

Map .............................. End of Volume

\section{APPENDIX}

Letters from Christian Wilt to John C. Luttig. .............. r29

Biographical Sketch of Sakakawea ................... 32

Biographical Sketch of Toussaint Charbonneau ............ 35

Letter from Major Joshua Pilcher to Hon. T. H. Crawford ........ 140

Biographical Sketch of Manuel Lisa ................. r $\mathbf{4}$

Letter from Lisa to "The Spaniards of New Mexico"........... 142

Biographical Sketches of:

Michael E. Immell. . . . . . . . . . . . . . . . . . . 143

Amos Richardson.......................... 144

Colonel Eli B. Clemson .................... 45

François Robidou.......................... 44

Louis Bissonet, dit Bijou.................... 148

Charles Sanguinet, fils...................... 149

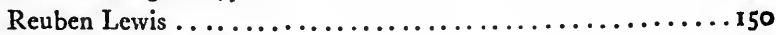

Major John Dougherty........................ 51

Jean Baptiste Point du Sable. .................. 53

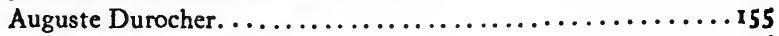

Antoine Citoleux, dit Langevin..................... 56

List of Engagés of the Missouri Fur Company, 1812-1813 ...... 157 


\section{.}




\section{INTRODUCTION}

Here is set forth the diary of a fur trader, giving an account of a voyage for the Missouri Fur Company, and the daily events at Fort Manuel. This unsigned manuscript, in the collections of the Missouri Historical Society, was thought worthy of publication, because, among other reasons, of its connection with two prominent members of the Lewis and Clark expedition, and of its circumstantial accounts of incidents of the fur trade.

The journal was kept in a hand-made book, without covers, thirteen inches long, eight inches wide, and containing fifty pages. It was written in a very good hand, as may be seen from the fac-simile page herewith.

The identity of the author was naturally the first subject of inquiry, and here was presented a difficult problem. There is nothing in the journal that gives any aid in this regard, excepting the handwriting and the style of expression. This latter feature, however, furnished a valuable clew. Certain faults in the spelling and use of the English language peculiar to persons of German origin and education, and the unusual formation of the letter " $c$," suggested a search for German names in the list 
of the engagés of the expedition. There are two such in the list, one of whom is John C. Luttig. While digging in the old St. Louis County court records I was rewarded by the discovery of papers signed by Luttig, and a comparison of the handwriting with that of the journal proved, beyond any doubt, that John C. Luttig was the author.

The next inquiry suggesting itself was for personal details concerning Luttig. Of course, it is evident that he was the clerk of the expedition, and this position was doubtless one of importance. We are informed by historians that the clerk was next in authority to the bourgeois, succeeding the latter in command during his absence, and frequently taking entire charge of posts. It was a part of his duties to keep a journal.

The course of German immigration in those early days pointed to the records of Pennsylvania as a proper field of research, but all of the work in that direction was without any gain or encouragement. Strangely enough, a wealth of material was right at hand. There is an old letter-copy book of Christian Wilt, formerly of Pennsylvania, in the Missouri Historical Society, and in this are many copies of letters making reference to Luttig, beginning with July 3 , 1813. From these references it appears that 
Luttig was a merchant of some importance in the city of Baltimore before coming to St. Louis. There is also evidence in the Missouri Fur Company account books that he served as clerk and assistant auctioneer at a sale held by the Fur Company at St. Louis in July, 1809, this being the first record of him in St. Louis. From documents in the court-houses at St. Louis and St. Charles it appears that Luttig sued Auguste Chouteau for salary and commission for serving as auctioneer when the personal property of Julien Dubuque, deceased, was sold at Mine d'Espagne (now Dubuque, Iowa), July 28, 1810. The petition in the case was in handwriting exactly like the manuscript journal.

From Christian Wilt's letters, copies of several of the most interesting being included in the Appendix to this volume, we learn of many of the personal characteristics of the author of the journal-at least from the view-point of Wilt. And this is the only source of information, as the Maryland records are barren of reference to Luttig or his antecedents.

It appears that Mr. Wilt engaged Luttig, sometime about July 3,1813 , to make a voyage from St. Louis to New Orleans in furtherance of Wilt's mercantile business, which included the manufacture of soap, the distilling of liquors, 
I4

and the operation of a mill. Wilt describes Luttig as a man who "unfortunately drinks, but who is an excellent hand to sell goods, is active and withal a very clever fellow." On September 18, 1813, Wilt tells of losing Luttig to Gov. Clark, who, he says, could not do without him. Ten months later, on July 5, 1814, Luttig seems to be on an expedition for Wilt "on the White River and in the Spanish country," he having started before that date on the voyage. He returned to St. Louis sometime in August, I8I4, having been the bearer of a letter from Major Lovely of Arkansas to Gov. Clark, of date August 9, 1814.

Luttig remained in the employ of Wilt until his death, which took place about July 19, I815, in the town of Lawrence, Arkansas, then part of the Territory of Missouri. Notice of letters of administration was published by Elizabeth Luttig and Moses Graham, joint administrators, in the Missouri Gazette, July 13, 1816. I have been unable to find any court record of this administration. A few months previous to his death Luttig was appointed justice of the peace "within and for the settlement of White River" in Lawrence County, by Gov. Clark.

The journal covers a period when the fur trade was at its worst. The war with England affected the Indians and consequently the fur 
trade. The St. Louis Missouri Fur Company went through a reorganization at this time and incorporated under the name of the Missouri Fur Company. In the expedition of this year, which cost about $\$$ II,$\infty 00$, the first boat started from St. Louis on May 2d, I812, and the other boat followed four days later. The expedition seems to have terminated in confusion and the diary, unfortunately, stops abruptly on March 3, 1813. The reason for all this seems apparent from the Missouri Gazette of June 5th, 1813, which contains an article in substance as follows:

"Mr. Lisa of the Missouri Fur Company arrived in St. Louis a few days ago from the Mandan villages on the Missouri; the Aricaras, Chyans, Grosventre, Crows and Aropahays are or may be considered at war with the Americans. The British Northwest Company, having a number of trading-houses within a short distance of the Missouri, are enabled to embroil our people with the savages, who are constantly urged to cut them off."

While the newspaper article says nothing about the number of men killed, Christian Wilt, in one of his letters, stated that fifteen of Manuel Lisa's men on this expedition had been killed by the Sioux and that the Mandan Fort had to be abandoned. Where and how the members of this expedition spent the time between March 
3 , the date of the last entry in the journal, and the arrival of Lisa in St. Louis in the early part of June, is an interesting problem. It certainly did not take all this time to make the homeward journey. The hardships must have been such as to discourage the keeping of a diary, or else the work devolved upon some other person. Lisa's difficulties with the Indians compelled him to leave the Arikara country, and having reached less hostile territory, he might have been able to concentrate his forces and establish himself among the Omahas. General Chittenden has suggested that the noted Fort Lisa, near old Council Bluffs, was erected during the War of 1812 . While I have not found any positive proof of the fact, I think the Fort was probably built on the return voyage of this expedition; at any rate, the great length of time consumed on their return could be explained in that way.

An expedition into the Spanish country is also mentioned in this journal. The enterprising Manuel Lisa, for the purpose of extending his operations into the Southwest, sent twentythree of his hunters to trade with the Spaniards; this was in about 1810. They went into the Arapaho country, under the leadership of Jean Baptiste Champlain and Jean Baptiste Lafarque, where they knew the Spanish traders 
would be found. Fearing that the McKnightChambers-Baird outfit, which left St. Louis after the Lisa party, might interfere with his plans, Lisa, on September 8, 1812, addressed a letter to the Spaniards of New Mexico. In this he urged them as his compatriots to communicate with him, enter into negotiations, or send someone back to Fort Manuel with his messenger. This letter, set out in full in the Appendix, and the entries in the journal bear somewhat on the mysteries surrounding Ezekiel Williams, and his experiences in Colorado.

An interesting letter from Williams, published in the Missouri Gazette, September 14, 1816, was reprinted in the Missouri Historical Society Collections, Vol. 4, p. 292. Williams, at the time it was written, was under suspicion of murdering his comrade, Jean B. Champlain, and for this reason sent the above-mentioned letter for publication. The facts gleaned from Lisa's and Williams' letters are these:

In 1810 , as stated above, Lisa equipped and sent twenty-three of his hunters to trade with the Arapahoes. After their return from a successful season, he again equipped and sent them back in charge of Champlain. Apparently, on this second trip, which no doubt left in the late spring of 1811, Ezekiel Williams joined the party. They journeyed south from the Mis- 
souri River and spent the winter on the Arkansas, where they hunted and trapped unmolested by the Indians. The next spring the Indians commenced harassing and robbing the company, and at the rendezvous on the Platte, as Williams says, in June, they took counsel with each other and decided it would be best to separate. Eight or ten crossed the Rocky Mountains, while the remainder, including Champlain and Williams, went south along the Mountains. In this respect Williams' and Luttig's versions are almost identical. (See entry of December 12, I812.) After crossing the Arkansas River, Williams and his party were informed by the Indians that the fort on the Missouri was broken up; that Manuel Lisa had fallen out with the Indians near there; and that the Indians and trappers were killing each other whenever they chanced to meet. The party then concluded it was impossible to return to the Missouri and divided up again, four deciding to try to find the Spanish settlements, and Champlain, two hired men, two Frenchmen, and Williams remaining together. After a few months (so. Williams says) of hunting and trapping, three of the party were killed by the Indians, leaving Champlain, Williams, and a man named Porteau. These decided to go to the Arapaho village for protection, where, ac- 
cording to Williams, they found the horses and equipment of their murdered comrades. The chief of this tribe advised them to spend the winter with him, assuring them of their safety and warning them that if they attempted to return they would surely be killed. Champlain and Porteau concluded to follow this advice and remained, while Williams decided to make an attempt to find the white people or other place of safety. After many vicissitudes, Williams reached Boonslick, after having been robbed and imprisoned by the Kansas Indians and rescued by the Osages. According to Major George C. Sibley, Indian Agent for the Osages, Williams reached Arrow Rock on November 30, 1813. The thrilling experiences of Williams constitute the basis of Coyner's Lost Trappers, an exaggerated and inaccurate narrative, to say the least.

Williams further tells about his seeing Manuel Lisa afterwards in St. Louis, of Lisa's recounting to him the difficulties they had with the Indians, and stating to him that his comrades had not returned; that they were certainly killed if they went the road which they talked about at the parting. This statement is somewhat questionable, considering the entry made by Luttig in December, 1812. Lisa then knew of Champlain's death, having sent three of his 
men, Charles Sanguinet fils, Charles Latour, and Chevalier cadet, in search of Champlain and his party, and they had returned without finding them.

In May, I8I4, Williams started back to the Arapaho village to recover the furs that he had left there. When he arrived, he inquired for his companions, and was told by the chief that three days after his departure they went up the river hunting. Soon afterwards they returned and decided to make an attempt to get back to the fort on the Missouri. They loaded all their furs on their eleven horses and started toward the Missouri; that later the Crow Indians told the Arapahoes that they had seen two white men dead in their camp, whom they believed were Williams' companions, Champlain and Porteau.

Unfortunately for Manuel Lisa and his company, as well as for McKni yht and his party, the time was not auspicious for trade with the Spaniards or the Southwest Indians, for the men of these parties who were not killed, or lucky like Williams, were thrown into prison to languish for many years.

The various expeditions conducted by the Missouri Fur Company were better known as "Lisa's expeditions." To speak of any one of them is to call to mind the personal character 
of Manuel Lisa. His successes as a trader are not more interesting than his influence over the Indians, notably in connection with the War of 1812. It may be well to quote from Lisa himself while commenting upon his methods and achievements. In his letter of resignation as sub-agent for the Indian tribes of the Upper Missouri, he reviews the subject with much earnestness and rises to the point of eloquence. Here he says:

"I have had some success as a trader; and this success gives rise to many reports. 'Manuel Lisa must cheat the Government, and Manuel Lisa must cheat the Indians; otherwise he could not bring down every summer many boats loaded with furs.'

"'Cheat the Indians.' The respect and friendship which they have for me, the security of my possessions in the heart of their country, respond to this charge, and declare, with voices louder than the tongues of men, that it can not be true. 'But Manuel Lisa gets so much rich fur!' Well, I will explain how I get it. First, I put into my operations great activity. I go a great distance, while some are considering whether they will start today or tomorrow. I impose upon myself great privations. Ten months in the year I am buried in the depths of the forest, at a vast distance from my own 
house. I appear as the benefactor, not as the pillager of the Indian. I carried among them the seed of the large pumpkin, from which I have seen in their possession fruit weighing one hundred and sixty pounds. Also the large bean, the potato, the turnip; and these vegetables now make a comfortable part of their subsistence; and this year I have promised to carry the plough. Besides, my blacksmiths work incessantly for them, charging nothing. I lend them traps, only demanding a preference in their trade. My establishments are the refuge of the weak and of the old men no longer able to follow their lodges; and by these means I have acquired the confidence and friendship of these nations, and the consequent choice of their trade."

In the matter of his efforts to prevent the English from effectively gaining the aid of the Indians during the war, it may be safely asserted that Lisa was of great benefit to his country. Had the English been successful in uniting the Sioux tribes, the effect upon the people of Missouri would have been very serious, and it is difficult to estimate the extent of damage which might have resulted to our cause. England had sent emissaries into the Indian country, using many artful methods to set them against the Americans. But Lisa, 
knowing the pliable nature of the Indian character, entirely overcame the English strategy with some of his own, and only lost a few of some of the tribes to the English cause.

It was during this war with England that Lisa received his appointment as sub-agent of the Indian tribes inhabiting the Missouri River above the mouth of the Kansas. At that time the British agents had armed all of the tribes of the Upper Mississippi and northern Lakes, as well as some of the Missouri River Indians, and Lisa himself was the victim of the first attacks against American citizens directed by the English. More than a year before the war broke out Lisa had warned Gen. Clark that the English were gaining considerable influence with the Indians along the banks of the Missouri River, by means of gifts and bribery, and that all the natives along that river were $b$ ing invited to join a universal confederacy of Indians, nominally for protection against the American invaders. He also asserted that the Indians of the Missouri were to the Upper Mississippi as four to one and that their weight would be very great should the English accomplish their purpose.

As it turned out, the Missouri River Indians used their arms against the British allies and struck the Iowas. When peace was proclaimed, 


\section{4}

more than forty chiefs "had intelligence with Lisa," and together they were planning a campaign of several thousand warriors against the tribes of the Upper Mississippi, expecting to quiet them with one blow. Part of Lisa's strategy was to excite war between some of the tribes, thus keeping them too busy with their own affairs to permit of intermeddling with the war between England and the United States.

In the same letter of resignation Lisa says, by way of conclusion: "These things have I done, and I propose to do more. The Ricaras and the Mandans, the Gros-Ventres and the Assinniboins, find themselves near the establishment of Lord Selkirk, upon the Red River. They can communicate with it in two or three days. The evils of such a communication will strike the minds of all persons, and it is for those who handle the power to dilate upon them. For me, I go to form another establishment to counteract the one in question, and shall labor to draw upon us the esteem of these nations, and to prevent their commerce from passing into the hands of foreigners."

The journal gives new light on Charbonneau, and the "Snake wife of Charbonneau," who can be none other than Sakakawea of Lewis and Clark fame. The references, taken together with certain well-known facts and records, tend 
to disprove a good many theories concerning both of these characters.

To the enthusiasm imparted by Judge Walter B. Douglas and his constant encouragement I owe the completion of this undertaking. His expert knowledge of the subjects of the diary have made his suggestions and criticisms of very great value. I am indebted and thankful to many others, especially to those mentioned in my notes.
Stella M. Drumm, Librarian, Missouri Historical Society. St. Louis, July 2, 1920. 

s,

. 


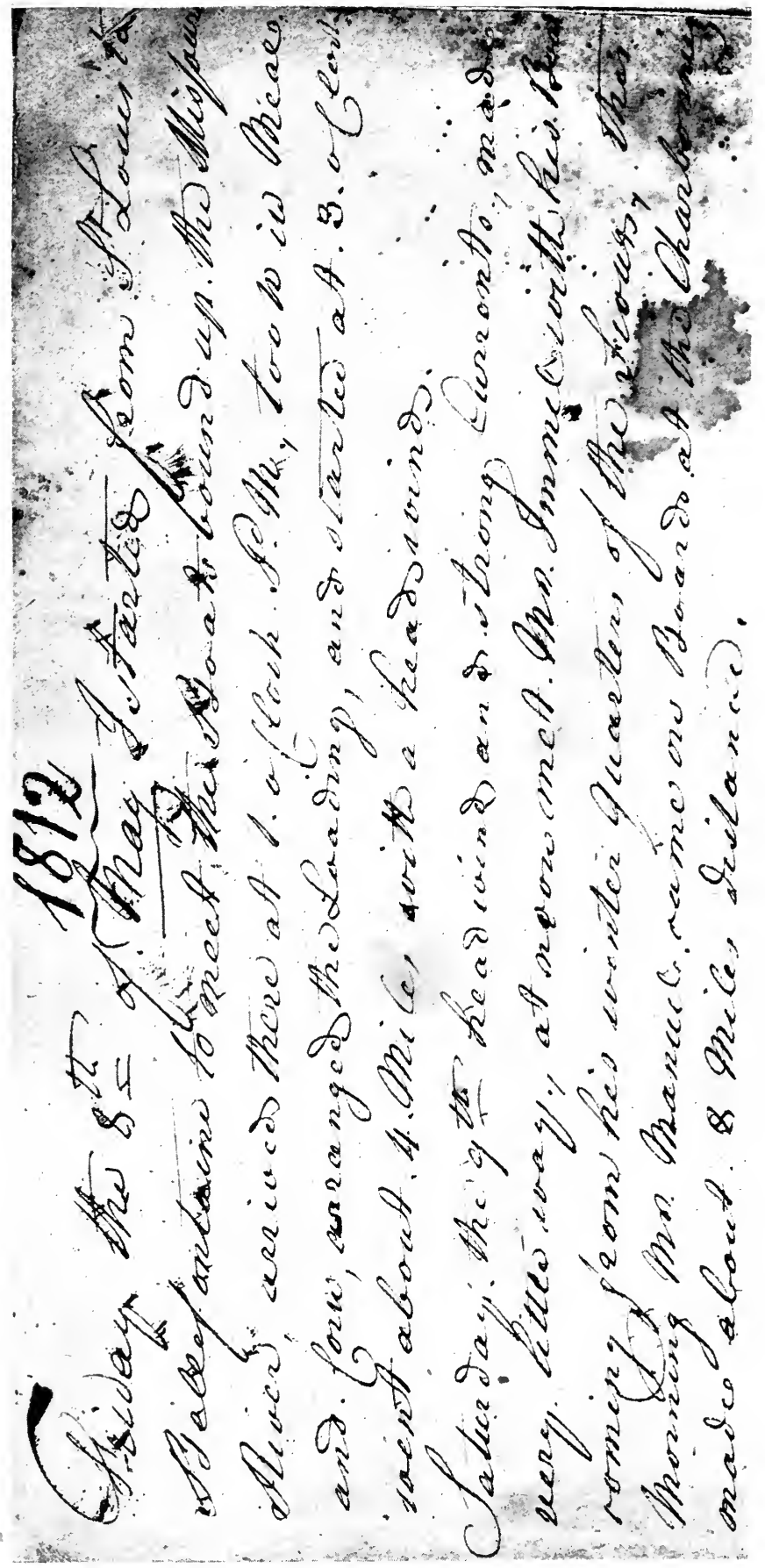




\section{JOURNAL}

\section{I8I2}

Friday the 8th of May I started from St. Louis to Bellefontaine ${ }^{1}$ to meet the Boats bound up the Missouri River, arrived there at $\mathbf{I}$. oclock P. M., took in. Meal and Corn, arranged the Loading, and started at 3. oclock, went about 4. miles with a head wind.

\section{Saturday. the 9th head wind and strong Cur-}

Fort Bellefontaine, first a Spanish military post, then an Indian Factory of the United States Government, and later United States Military Fort, was located on the south bank of the Missouri River, 4 miles above its mouth, and 15 miles from St. Louis, in what is now St. Louis County, Missouri.

The Indians demanding a military post at this point, it was stipulated in a treaty made at St. Louis, November 3, 1804, between William H. Harrison, Governor of Indiana and the District of Louisiana, and the head chiefs of the Sac and Fox tribes of Indians, that the United States would establish a trading-house or factory at a point where these tribes could be supplied with goods at a more reasonable rate than they had been accustomed to enjoy. In accordance with this agreement, in August, 1805, Gen. James Wilkinson, then commanding the Army, was directed to select a site for the proposed factory and to occupy the same with troops. On the roth of August, 1805, he reported that his troops had encamped at " Cold Water on a high, dry narrow bottom of the Missouri River near a fountain of pure water, competent to supply I,000 men daily," * * "and where they are now actively engaged on the work of the cantonment, and in collecting materials for building of the factory." This cantonment was given the name of Fort Bellefontaine for the abundant spring of pure water in its midst. Col. Thomas Hunt was first in command at this post. In 1808 the Indian factory, which had been during its existence under the charge of Rudolph Tillier as Factor, was discontinued, because it was found to have been inconveniently placed.

From 1809 to 1815 Fort Bellefontaine was the headquarters of the Department of I.ouisiana, which included Forts Madison, Massac, Osage, and Vincennes, and during the War of 1812 was frequently threatened by marauding bands of Indians

On July ro, 1826 , the cantonment was abandoned as a military post in favor of a larger and permanent fort below St. Louis, although a small arsenal of deposit was maintained at Fort Bellefontaine until 1834. Only the stone magazine building is still standing. 
rents made very little way, at noon met $\mathrm{Mr}$. Immel ${ }^{2}$ with his Boat coming from his winter quarters of the Sioux, this Morning Mr. Manuel came on Board at the Charbonnier made about 8 miles distance.

Sunday. the Ioth, came too opposite ${ }^{4}$ St. Charles ${ }^{8}$ at noon Mr. Manuel Lisa crossed for some Men, rested all Day.

Monday the IIth Mr. Manuel Lisa \& Choteau ${ }^{6}$ came on Board at 9. oclock A. M. took in some traps, and made the best of our way at 12. oclock, having a head wind made very little distance.

Thuesday. the 12 th, head wind and strong Current, made not much Distance.

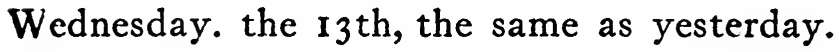

Thursday. the rith, the same

2For a sketch of Michael E. Immell, see Appendix.

'La Charbonniere, the name given to a coal-bank on the right shore of the Missouri River, near Florissant, and about twelve miles above its confluence with the Mississippi. In French this word strictly means a place in the forest where coal is made, but as applied to the bluff on the Missouri it means the place where mineral coal is procured.

'Bonhomme Township, St. Louis County, Missouri.

iSt. Charles is situated on the north bank of the Missouri River, about thirty miles above its confluence with the Mississippi. It is the seat of justice of St. Charles County, and was the first capital of the State of Missouri. St. Charles was settled by the French about 1785, who called the place "Les Petite Cotes" and "Village des Cotes," from the fact that the village was situated at the foot of a range of small hills. The place was officially known as St. Charles soon after its settlement, as a concession from the Spanish Government to Auguste Chouteau, in 1787 , is described as being for fifteen arpents of land above St. Charles, while a letter from the Spanish Governor, in 1792, refers to the village as "San Carlos."

Probably Pierre Chouteau brother of Auguste Chouteau, one of the founders of St. Louis. 
friday. the $15^{\text {th }}$ in the Morning about 8 oclock Mr. Majet, ${ }^{7}$ Patroon $^{8}$ of the large Boat fell over Board on account of a Log shamming against the Rudder, he saved himself by taking hold of the Rudder, and got on Board, both Rudder Irons. brocke and Lost, were detained to make a steering Oar, head wind all Day, sent some Irons on shore by $\mathrm{Mr}$. Richardson, ${ }^{9}$ and camped at Burgois Creek. ${ }^{10}$

\section{Saturday. the 16, detained on Account of the Iron, which however came about I I oclock A. M., hard Rain and bad weather, fixed the Rudder and went about 2 Miles distance. Killed I Deer.}

'Jean Baptiste Mayet was living in Carondelet, St. Louis County, Missouri, in 1790. On April 17, 1807, he left St. Louis with Manuel Lisa on a trapping expedition and returned in August, 1808. He continued in the employ of Lisa and the Missouri Fur Company for a great many years, and they seem to have found him both competent and trustworthy. Mayet married by civil contract, in 1816 , Joeette Demaret, and on July 8,1821 , the marriage was solemnized in the Catholic Cathedral in St. Louis.

8Patron. The crew of a keel-boat-in the fur trade called a "brigade"-frequently consisted of as many as a hundred men, although this number included many hunters and trappers, en route to the mountains, who were not regular boatmen. They went well armed, and every boat carried on her bow a small cannon, called a "swivel.", The captain of the boat, called the "patron," did the steering, and his assistant, called the "bosseman," stood on the bow, pole in hand, and gave directions to the men on the cordelle. It was necessary that these officers should be men of great energy, physical strength, and personal courage. The sail was seldom used, except in the upper river, where the absence of timber rendered the wind available. (Chappell, Phil E., History of the Missouri River, 1905.)

'For a sketch of Amos Richardson, see Appendix.

"Berger River, or Creek, is the "Shepherd River" of the Lewis and Clark journals. Berger Creek comes into the bottom two miles above its mouth and is here joined by Little Berger Creek, which runs about four and a half miles in the bottom before its confluence, and the two make what is known as Berger's Bottom, forming a sort of island six or seven miles long. (Coues ed. Pike, 2:365.) 
Sunday. the $17^{\text {th }}$ blowing very hard ahead and strong Current we had to stop for several hours, made sail about 2 P. M., just at starting a Bear crossed the River towards us, Killed him close in shore, and found him very fat.

Monday. I 8 th, still head wind the Rudder Irons of the little Boat brocke, and had to lay by all Day. this Day killed four Deer 2 Turkeys.

Thuesday. rgth bad weather and head wind made about one mile all Day distance.

Wednesday 20, head wind and strong Current, made not much Distance.

Thursday, the $2 \mathbf{I}$. arrived at II. oclock A. $M$. at Cote sans Dessein, ${ }^{11}$ rested all Day. traded . some Beaver, and took LaChapel ${ }^{12}$ on Board.

Friday. the 22d. started at 6 in the Morning

"Cote sans Dessein was the first settlement of white men in Callaway County, having been established as a village by the French traders, who erected a fort there, in 1808 . It was once a village of considerable importance, containing a block-house during the War of 1812 , and being the scene of some hard-fought battles with the Indians. It has ceased to exist, however, even the post-office having been discontinued. The township now including the place of former settlement has been given its name, and the hill which marked the place, and from which the name Cote sans Dessein is derived, can still be identified.

${ }^{12}$ Jean Baptiste Lachapelle was the son of Jean Baptiste Lachapelle of Kaskaskia, Illinois, and $\mathrm{Cija}$, an Osage Indian woman. $\mathrm{He}$ was born in St. Louis, October 10, 1792, and was probably the grandson of Bazile and Marie (Lumandiere) Lachapelle of Montreal, who came to Kaskaskia about 1760 . The name was originally Janot, and in the Kaskaskia records it is frequently designated as Lachapelle, dit Janot. Jean Baptiste Lachapelle, fils, was in the employ of the Missouri Fur Company from its organization until its dissolution, serving part of that time as a free trapper. He was no doubt a kinsman of Louis Lachapelle, interpreter at the Pawnee village, who was slain in battle there June 27, I 843; also of David I.achapelle, hunter and interpreter at the Arikara and Pawnee villages, mentioned by Murray and Maximilian. 
with a favorable breeze, found the River more gentled, had fine weather. Killed two Deer and I Bear, made good head way.

Saturday, the 23d, fine weather \& fair wind made about 25 miles distance. Killed I Deer.

Sunday. the 24th clear weather and fair wind made about 20 miles, and camped about I mile above the Widow Cole, ${ }^{13}$ Killed I Deer and I Bear.

Monday the $25^{\text {th }}$ commenced with a thunder storm and hard Rain, cleared up about II A. M. with a fine fair wind, made about 27. Miles, and killed I Bear.

Thuesday the 26, hard Rain and squalls all Day made not much distance, killed I Bear 2 Turkeys.

Wednesday, the 27. bad weather and head wind again, killed two Deer, and made not much distance.

15This was Hannah Cole, who erected a fort on the edge of the bluff near the River. in what is now East Boonville, Cooper County, Missouri. Before her marriage she was Hannah Allison, and married William T. Cole of Wythe County, Virginia. In I80I the Coles with their nine children emigrated to Wayne County, Kentucky, where they remained seven years, and then moved to Missouri, locating on Loutre Island. During the second year (1810) of the family's residence on Loutre Island, William T. Cole was killed by the Indians. Soon after this event, the widow and her children, together with her brother-inlaw Stephen Cole and his family, went to Cooper County, they having the distinction of being the first white families to locate west of Franklin County and south of the Missouri River. Mrs. Cole was a very heroic and energetic woman. She secured a license to operate the first regularly established ferry in that county, and it was in her home that the first session of the Circuit Court was held in 1816. The children of William T. and Hannah Cole were: Jennie, Mattie, Dikie, Nellie, James, Holbart, Stephen, William, and Samuel. 
Thursday. the 28, head wind and strong Current accompanied by heavy Squalls, LaChapel killed a fine female Bear, and 3 of her Cubs, and I Turkey, made only 5 miles this Day and camped at black snake Creek. ${ }^{14}$

friday. the 29th departed at Day light, opposite the little Osage Island ${ }^{15}$ we were obliged to stop on account of head wind and strong Current, arranged a new top Mast, went fishing with the Seine and caught 13 large fish I Turtle, the wind having comewhat abated we made way at $2 \mathrm{P}$. M. but still wind ahead, at the little Osage Prairi ${ }^{16}$ we stopped for the little Boat which got aground, met a shoal of Cat fish close in shore the men who were Cordelling killed one with a stick which weighed after cleaning $40 \mathrm{lbs}$, went on a little way and found a small Run full of fish, the other Boat not having come up as yett we took our Seine and caught I6I Bass and oth-

14Lwis and Clark camped on Black Snake Creek on their outward voyage, June 14,1804 . It is not shown on the present maps.

15Little Osage Island, near the site of Fort Orleans, which was established in 1721 by Etienne Venyard de Bourgmont.

${ }^{10} \mathrm{Little}$ Osage Prairie, called Petite-sas-Plains, in Saline County, Missouri, about seventeen miles above the mouth of Grand River, was the site of the ancient village of the Little Osage Indians, and was one of the most historic spots in Missouri. It was at one time the home of the Missouris, as well as that branch of the Osages known as the Little Osages, or the Little Tribe. Mr. Phil E. Chappell, in his Hisory of the Missouri River, says that "the loc ation of these villages was still sufficiently well defined to be accurately determined." When Lewis and Clark passed this prairie in 1804, the remains of the villages were pointed out to them. The location was well known then, as the villages had only been abandoned about thirty years previous. It is interesting to reflect that this location was the site of a settlement, in earlier days, of a tribe of Indians having much higher degrees of culture and industry. (Fowke, Antiquities of Central and Southeastern Missouri. Bureau of American Ethnology, Bulletin 57.) 
er fish, which we salted, camped and killed 2 Deer.

Saturday, the 3 oth fine weather, but very hard water, swung 3 times at a point of a sandbar, the little Boat brocke her Rudder Irons again, repaired at Dinner, Killed 2 Deer I Bear I Pelican, made not much Distance.

Sunday. the 3 Ist fortune still ahead, strong Currents and head winds were our Daily Companions, made no way. Killed 2 Deer and I Beaver.

Monday the Ist of June, hard wind a head with fine weather met 4 Batteaux going to St. Louis, a little above the Prairie du foe (feu $)^{17}$ had to stop and made another top mast of Oack, the last one made of Hichberry was crooked and good for nothing, Killed 3 Deer I Bear.

Thuesday, the $2 \mathrm{~d}$, the wind and weather the same as jesterday. Killed this Day 2 Deer and I fox, camped at fire Prairie Creek. ${ }^{18}$

Wednesday the $3 \mathrm{~d}$ fine weather and head wind and Curren as usual at Io A. M. arrived below fort Osage, ${ }^{19}$ saluted with 17 Guns which was politely returned by the Commander

${ }^{17}$ Fire Prairie was so called from the circumstance of three or four Indians having been burned to death from the sudden conflagration of dry grass in the meadows at its source." (Long's Travels, London ed., 1823.)

${ }^{18}$ Fire Prairie Creek, in Sni-a-bar Township, Jackson County, Missouri, rises and flows north and east into Lafayette County, and thence into the Missouri.

${ }^{19}$ Fort Osage was frequently called Fort Clark and Fiery Prairie Fort. 
Capt Climson, ${ }^{20}$ on arrival were invited to Capt Climson, who treated us very handsomely, discharged our freight for this place and arranged our Cargoes, had a present made of Ice, which regaled us exceedingly.

\section{Thursday the $4^{\text {th }}$ started after breakfast, about 9 A. M. met several Perogues coming from their Winter quarters, Mess fr Robideau ${ }^{21}$ La Jeuness ${ }^{22} \&$ others, Louis Bijou ${ }^{23}$ embarked with us, as also two hunters embarked at}

It was situated on a bluff on the south side of the Missouri River, a short distance from where the town of Sibley now stands in Jackson County, Missouri. The site was chosen by Gen. Clark for a Government trading factory and fort. It was christened with the customary parade and salute on November 13, 1808. George C. Sibley was in charge as Indian Agent and factor for many years, and after the abandonment of the fort the town which occupied the site was named for him. In June, 1813, during the war with England, the fort was evacuated. Major Sibley and his men removed to Arrow Rock, where was erected a fortified two-story block-house, 30 feet by 20 feet, armed with a swivel and three blunderbusses, affording sufficient room for goods, for trading, and for fighting. The garrison was restored at Fort Osage in 1816 , but was thereafter only intermittently maintained. In 1822 it was practically abandoned, and after the treaty with the Osages the United States Government was relieved of the necessity of maintaining the post. Upon the erection of Fort Leavenworth in 1827 Fort Osage was permanently abandoned.

${ }^{20}$ For a sketch of Colonel Eli B. Clemson, see Appendix.

2For a sketch of François Robidou, see Appendix.

${ }^{22}$ There were two men of this name active in the fur trade during this period. One, Jacques Lajeunesse, a native of Riviére du Chambly, Quebec, son of Ambrose and Marie (Goyet) Lajeunesse, who married at St. Louis, October 7, 1799, Helene Vasseur, the daughter of Joseph and Helene (Picard) Vasseur. Of this marriage eight children were born: Marie, Margaret, Louis, Julie, Antoine, Elizabeth, François, and Joseph. The other was Jean Baptiste Lajeunesse of St. Rose, Quebec, son of Jean Baptiste and Reine Naulette. He married at St. Louis, July 9, 1797, Elizabeth Malbceuf of Lac des Sables, daughter of Francois and Josette, an Indian. This is probably the man we read about in Lewis and Clark. Lajeunesse was a very common name in St. Louis, and many of the men were conspicuous in the fur trade.

${ }^{23}$ For a sketch of Louis Bissonet, dit Bijou, see Appendix. 
fort Osage Greenwood ${ }^{24}$ \& Laurison, ${ }^{25}$ Immel went back to the fort for his Dog and on his Return informed of the party going to Santa $\mathrm{Fe}^{26}$ he met this Day at the fort. strong Current, Made 9 Miles distance.

${ }^{24} \mathrm{Caleb}$ Greenwood was an American, born possibly as early as $\mathbf{1 7 6 3}$. He was in the employ of Gen. William Ashley from 1822-1825, and the American Fur Company in 1833. In this last-mentioned year he sought engagement as interpreter and hunter for Rev. Moses Merrill, missionary to the Otoes. He then told Rev. Mr. Merrill that he had been in the Indian country for twenty-six years; that he had just left the services of the American Fur Company and was at that time on bad terms with its agents.

In 1844 he guided the Stevens party to California and later served in Micheltorena's army against Alvarado and Castro. Edwin Bryant met him in 1846 at the head of a party of hunters near San Francisco Bay. Greenwood then claimed to be eighty-three years old and had with him three sons, the youngest about ten or twelve years old. He stated that he had been a mountain trapper between forty and fifty years. He lived among the Crow Indians and married into that tribe. He is described by Bryant as being about six feet tall, raw-boned, and spare in flesh, but muscular, and, although of great age, having the elasticity and erectness of youth. Greenwood had just come over the mountains from the Sweetwater as pilot for emigrants and complained of the bacon, bread, and milk which they had to eat as being "mushy stuff," and not fit for a man of his age. He said he wanted a small hunt to get some exercise and some good fresh meat, such as grizzly bear, fat deer, and poultry, which he considered fit things for a man to eat.

25Daniel Larrison was with the Missouri Fur Company for several years, and was with Lisa's party in the expedition to the Rocky Mountains in 1809 . He returned to St. Louis in September of the following year. In October of 1813 , following the return of the expedition referred to in this journal, he is to be found trading among the Osage Indians. He was sent by them to the Kansas village when the Osages learned that there was a white man (Ezekiel Williams) held prisoner in that village, in order to rescue him. In 1814 Larrison joined Capt. James Callaway's company of St. Charles County Rangers, and was in the expeditionary forces under Maj. Zachary Taylor, operating that year on the Upper Mississippi. Daniel Larrison probably lived in St. Charles, Missouri, but nothing about his personal life has been found. There was a John Larrison with Gen. Ashley's party in 1823, who was wounded in July of that year, when this party was attacked by the Arikaras.

${ }^{28}$ The Santa Fe Party consisted of twelve men, under the leadership of Robert McKnight, James Baird, and Samuel Chambers. They 
friday the 5 th wind and Current as usual. fine weather made about 12 miles distance Killed I Deer.

Saturday. 6th the same wind \& Current, Killed 3 Bear 3 Deer I Turkey camped opposite Cansas River ${ }^{27}$ distance I 5 Miles.

Sunday the 7 th a fine morning, in the afternoon cloudy and distant Thunder, Killed 2 Deer, made 16 Miles distance, camped 4 Miles above little Platte River. ${ }^{28}$

Monday. 8th fine weather, at 8 A. M. a fair Breeze sprung up. though feeble, we made I8 Miles distance, Killed 3 Deer 3 Bear, caught 17 fish, camped 2 Miles below the old Cansas $^{29}$ Village.

planned to trade with the Mexicans at Santa Fe, but on their arrival in New Mexico were seized as spies and their goods confiscated. They were sent to Chihuahua, where they were kept in prison for nine years.

${ }^{27}$ Present site of Kansas City, Missouri.

${ }^{28}$ The Little Platte has its source in southern Iowa, and flows south to the Missouri River in Platte County, Missouri. Its mouth is at Parkville. The position of the mouth of the river has changed much since 1812 .

${ }^{20}$ Kansas Indians. Major George C. Sibley visited the Kansas Indians in August, $181 \mathrm{I}$, and gave a most interesting account of them, as follows:

"The Konsee [as he spells it] town is seated immediately on the north bank of the Kansas River about 100 miles by its course above its junction with the Missouri, in a beautiful prairie of moderate extent, which is nearly encircled by the river.

"The town contains 128 houses, or lodges, which are generally about sixty feet long and twenty-five feet wide, constructed of stout poles and saplings arranged in the form of an arbour, covered with skins, barks, and mats. They are commodious and quite comfortable. The place for fire is simply a hole in the earth under the ridge-pole of the roof, and where an opening is left for the smoke to pass off. All the larger lodges have two, sometimes three, fire-places, one for each family dwelling in it.

"The town is built without much regard to order, there are no 
Thuesday 9th headwind again, strong Current, made only 9 Miles distance this Day, Killed 6 Deer.

Wednesday. roth, fine weather, and a small Breeze in our favor, Killed nothing today, distance made, 19 Miles.

\section{Thursday the IIth, fine weather head wind but still, all hunters out, passed the upper old Cansas Village, Killed 7 Deer, distance 15 Miles.}

friday the 12 , fine weather, made good way cordelling the wind all Day against us, distance

regular strects or avenues; the lodges are erected pretty compactly in crooked rows, allowing barely enough space sufficient to admit a man to pass between them.

"The Kansas River is about 300 feet wide at the town, and is, I suppose, always navigable for large keel-boats as high as the village. At this time the Kansas may number near about 250 fighting men, with a fuli proportion of women and children.

"Thcy are gcverned by a chief and the influence of the clidest and most distinguished warr ors. They are seldom at peace with any of their neighbors, except the Osage, with whum there appears to be a cordial and lasting triendship.

"The Kansas are a stout. hardy, handsome race, more active and enterprising even than the Osage. They are noted for their bravery and heroic daring. They maintain tineir independence against the Pawnees, Otoes, Missouris, and other tribss with whom they are continually at war, entirely hy their bravery. Previously to the cession of Louisiana, the Kansas committed frequent acts of violence upon the French traders, robbing, beating, and otherwise cruelly treating them. One instance is related of their having actually burned some alive."

These Indians had their villages for a time on the south bank of the Missouri, and while there were quite numerous. They were subsequently attacked by the Cheyennes, Sauks, and Iowas and compelied to return to their former settlements at the mouth of the Kansas. Lewis and Clark found them in two villages on the Kansas River, one about twenty and the other forty leagues from its mouth. In 1847 they moved to Council Grove, where they rcmained until 1873. At this later date they went to Indian Territory. Eforts to civilize this tribe of Indians met with little success for many years. 
2I Miles camped on a large Sandbar where we found a quantity of turtle Eggs, this Day lost one of our Swivels when swinging round and run against the other Boat, Killed 3 Deer 2 Turkeys.

Saturday. the I3th fine weather and head wind, this Day had bad luck, crossing for some of our Hunters we came in hard water, and cordelling on a Prairie encountered many Rafts, after having passed we dined 2 Miles above the Prairie. ${ }^{30}$ Mr. Manuel L. put our 2 Hogs. in the River to wash but they swam off, we were obliged to turn about and followed them several Miles, after two Attempts we caught them, turning a rocky point we had hard work, the little Boat which was a head swung round and went off like Lightning, the Cordells broke, and we were obliged to put the hands of both Boats to one to mount-distance 12 Miles Killed 5 Deer I Racoon.

Sunday. the I 4 th fine weather, but head wind, passed the Nadowa River ${ }^{31}$ at noon, camped 8 Miles above made 16 Miles distance and had this Day 4 Deer Killed gathered about 200 turtle Eggs.

30Prohably Reevey's Prairie as mentioned by Capt. Clark in his journal, which place, he adds, was named for a man who was killed there.

31Nodaway, as it is spelled by present geographers, having had many variations in ics spelling, such as Nadawa, Nodawa, Naduet, and Nadoway. Coues, in his History of Lewis and Clark Expedition, says that the word "Nodaway" is Indian, and means some kind of snake; hence the river has sometimes been called "Snake River." The river separates Holt County, Missouri, on the west from portions of Andrew and Nodaway Counties. It was on the shore of this river that the winter camp of the Astorians was located. There is a county, and also a town, bearing the name of this river. 
Monday. 15th about one oclock this Morning it began to blow furiously, were obliged to put out our fires, the wind blowing from all quarters, a clear Sky, finished our cooking in the morning, started at 6 . in the Morning went $1 / 2$ Miles but were stopt by hard head wind and Current crossed the River to find some Hickory for making Axe handles and Ramrods, but were disappointed, crossed again and stopped till 5 P. M., started about I Mile took the Cordell the Boat swung and went down the River like the Wind in full Speed, leaving all hands on shore, the few which were on Board landed the Boat opposite to our last nights Lodging, our hands came on board made a new start, but night overtook us, got on a sand bar and were very near lost running against a Sawjer ${ }^{32}$ had to cross again to the North Side, the other Boat came to close swept by the Current we unshipped our Rudder, run against a tree and brocke her mast, this ended this doleful Day camped at II. oclock at night distance I I/2 Mile, left our hunters on the opposite side Killed I Deer, wind N. W. fresh Gales.

Thuesday the 16 , hard wind from N. W., went about I Mile in the Morning when we had to stop, all hands went out to gather wood for axe helm, Ramrods and a new Mast, and Game, the first was found but no meat, our hunters on the opposite Side had also been

${ }^{32} \mathrm{~A}$ "sawyer" is a snag or tree so fixed in the river that it oscillates or bobs up and down by the force of the current, and forms a special danger to navigators of the Missouri River. 
unsuccessful, and crossed the River on a Raft, facing wind and Current about 6 Miles swimming. Killed I Deer.

Wednesday $17^{\text {th }}$ wind still a head, but abated, made this Day 16 Miles, Killed 3 Deer, when camped a fair breeze sprung up.

Thursday. the 18 th at 3. oclock in the Morning a heavy Thunder storm, at starting we had a fair wind which however lasted not long, had to try oars. Poles \& cordells all Day, passed Nimohar River ${ }^{33}$ at II A. M. dined at Wolf River, ${ }^{34}$ and camped on a Sand Bar, made 16 miles distance Killed 3 Deer.

friday, the 19th During Night blew very hard until 6 in the morning, we stopped for some time having head wind and strong Current, the River high, made this Day about I 5 Miles distance by hard work. Killed nothing, allthough 7 hunters out of Boats.

Saturday, 2oth, hard Gales all night, in the Morning cloudy with some flaws of wind in our favor, about $8 \mathrm{~A}$. M. the wind increased, and we sailed at Intervals very fast, untill 2 P. M. when a Thunder storm attended with a hard rain arose. this Day. at ro. A. M.

${ }^{33}$ The Big or Great Nemaha, variously written Nimemeha, Nimaka, Nemahhaw, Nidonahaw, by early explorers and trave!lers. It rises in Lancaster County, flows in a southeasterly direction diagonally through Gage, Johnson, Pawnee, and Richardson Counties, Nebraska, and joins the Missouri just above the Kansas-Nebraska line.

${ }^{34}$ Wolf River (the early French maps give it as Riviére du Loup) flows through Brown and Doniphan counties, Kansas, and into the Missouri just below Iowa Point. 
passed Ichinipokine River ${ }^{35}$ at the North Side, at 7. P. M. little Mahonir River ${ }^{36}$ on the South Side,-made about 20 Miles distance, Killed 2 Deer, Game scarce.

Sunday. the 2Ist fine weather with head wind and Currents, all hunters out, on the Island Beaux Soleil. ${ }^{37}$ Killed 2 Deer 3 Bear, I Turkey. I Rabbitt the hunters on the Prairies killed nothing, distance about 15 miles, camped I Mile above the Island.

Monday. the 22d, cloudy had now and then some Sailing, the River still rising and strong Currents, at ${ }_{4}$ P. M. a thunder storm arose which raged furiously, the huricane swayed the trees every where luckely we got under some Villars and lay safe, were obliged to Camp., distance ro Miles, Killed I Deer, I Turkey.

\section{Thuesday the $23 \mathrm{~d}$, started at Day light as us-}

${ }^{35}$ Ichnipokine River is now known as Nishnabotna, an Indian word signifying "Good Canoe" or "Canoe Making River." This is another name having numerous styles of spelling. It is a Missouri tributary of considerable size, entering Atchison County, Missouri, on the north line, and following the bluffs in a southeasterly direction. Its channels are constantly changing. Some ycars ago the stream cut its channel into the Missouri River at a point near the north line of the county and emptied its waters into the Missouri some forty miles above its original mouth. There is a village bearing this name close to the present mouth of the Nishnabotna.

${ }^{20}$ Little Nemaha has its source in Cass County, runs through the county in Nebraska which bears its name, and empties into the Missouri between the towns of Aspinwall and Nemaha. It runs parallel with and from ten to fifteen miles north of the Great Nemaha. There are a town and a county in Nebraska, as well as a county in Kansas, bearing the name of this river. The Little Nemaha is a smaller edition of the Big Nemaha and also has numerous tributaries.

${ }^{37}$ Isle à Beau Soleil, or Fair Sun Island, now known as Sun Island, located midway between Peru and Brownsville, Nebraska. 
ual, passed le Cote grand Brule, ${ }^{38}$ opposite the head of, we had to stop to make a new top Mast for the other Boat. fine weather, Current very hard, River still rising, distance I4 Miles, Killed 3 Deer.

Wednesday. the $24^{\text {th }}$, St. John, ${ }^{39}$ started at 3 in the Morning with fair wind, but had not come $1 / 4$. Mile when the Wind changed ahead, worked hard against the Current, very warm and clear, made only 9 Miles in 14 hours distance, Killed I Deer 2 Turkey, 2 Racoons. found plenty fresh tracks of Elk.

Thursday. the 25th This Morning a fine breeze sprung up and we had sailing all Day, but by the Mismanagement of the Patroon of the little Boat were detained several times we camped before Sunset to lett the little Boat come up with us, about dark we heard a Gun, but she did not come to our Camp, the wind blew fresh all night made about 15 Miles distance.

Friday the 26 th at 2. oclock 25 Minutes in the Morning we turned about, to look for the little Boat and found her safe I Mile below our Camp, we set sail, and went pretty well till Sunrise, when the Wind failed, very strong Current, and hard work to gain way., at 7 A. M. Baptist Latoulipe ${ }^{40}$ of St. Louis, fell

${ }^{38}$ Cote Grand Brulé must be "Bald-pated Prairie," so named by Lewis and Clark "from a ridge of naked hills which bound it, running parallel with the river as far as we could see, from three to six miles distance."

${ }^{38}$ The anniversary of the birth of St. John the Baptist.

${ }^{40} \mathrm{Jean}$ Baptiste Latulippe. Tanguay gives more than half a dozen 
over Board and never seen again, the two Boats being close together, he could not rise, or was entangled by the Roots of a large tree, which he was going to strike with his Pole.-made River Platte ${ }^{41}$ at I I. A. M, dined

variations or dit names of Latulippe. In the census of 1787 for the District of Ste. Genevieve there is a José Latulippe listed as a stonemason, who worked on Fort Celeste at New Madrid.

Jean Baptiste on July 22, 1805, was engaged by Louis Aimable Demarais to hunt beaver from September until the May following, but no place of destination was given in the engagement. In August, 1806, he was in the service of Auguste Chouteau on the Osage River, and was used as a messenger by Gen. Zebulon Pike on August 14, 1806. (Doc. No. 8 of Appendix to Part 2.) Coues, in his edition of Expedition of Zebulon M. Pike, expresses the opinion that this Latulippe and the one mentioned by Fremont are the same. In this he is mistaken, as in the list of Fremont's engages, in the introduction to his report of 1845 , the name is given as François Latulippe. Gen. Fremont tells of meeting, in 1843 , an old friend, "a hardened and hardly-served veteran of the mountains, who flourished in the sobriquet of La Tulipe, and his real name I never knew."

Jean Baptiste Latulippe remained in the employ of Chouteau until the organization of the St. Louis Missouri Fur Company, when he joined its forces.

In Dr. John Farrar's account-book of 1813 is the following entry: "Mrs. Elizabeth Laturlipe, To visits to children and servants and your own child, May to August, 1813, A. P. Chouteau to pay." Letters of administration on the estate of Latulippe were granted to A. P. Chouteau January 24,1813 , which was probably near the time when news of his death first came to St. Louis. Unfortunately, the only paper in the files of this estate in the St. Louis Probate Court is the bond of A. P. Chouteau as administrator, being for the sum of $\$ 25.00$. In the files of the estate of Auguste Chouteau, deceased, are to be found two notes signed with a mark by Latulippe in favor of the former, one dated February 20, 1808, payable in skins, and the other dated August 12, 1810.

Latulippe probably came to Missouri from Vincennes, as there was a Latulippe family there in $\mathbf{1 7 7 3}$.

${ }^{41}$ The Platte is the great western tributary of the Lower Missouri. It is a broad, shallow stream with low banks, about 1,200 miles in length, draining most of Nebraska and portions of Wyoming and Colorado. Its mouth is taken as the line between the Upper and Lower Missouri. Platte is the French form of the name; the river has been called the Nebraska and the Flatwater. "The Platte is regarded by the navigators of the Missouri as a point of as much importance as the equinoctial line amongst mariners. All those who had not passed it before were required to be shaved, unless they could compromise the 
and weather very hot, remained three hours., at 3 P. M. passed River Papillion ${ }^{42}$ made 12 Miles distance, Killed I Deer.

Saturday. the 27th departed as usual and the Water not so strong as below the River Platte, this Morning passed Mosquito River, ${ }^{43}$ distance 20 Miles, Killed 4 Deer I Goose.

Sunday the 28 th, made pretty good way in the Morning but about Io A. M. the Rudder stay brocke of the little Boat we were obliged to cross the River to find a place to unload her, and make a steering Oar, which took up all Day. distance 6 Miles, Killed I Deer.

Monday the 29th This Day had at Intervals some sailing the River crooked as a zick zack, passed River Boje (4) $^{44}$ A. M. point Jacques ${ }^{45}$

matter by a treat. Much merriment was indulged on the occasion." (Brackenridge.)

42Papillon Creek (from a French word meaning Butterfly) is in Sarpy

County, Nebraska. Lewis and Clark camped here for several days on their upward journey to treat with the Indians. The town of Papillon is the county seat of Sarpy County, situated on the south fork of the Papillon. Ramsey Crooks and Robert McClellan had a trading-post, in 1810,2 little above the creek.

430squito Creek runs in a southwesterly course entirely across Pottawattamie County, Iowa, touching the city limits of Council Bluffs, and entering the Missouri Valley a short distance below the city.

"Boyer Creek (or River, as it is now called) winds its way through several counties of western Iowa, and joins the Missouri about ten miles above Council Bluffs. It was sometimes called Roger Creek. It was explored in 1820 by Thomas Say, of Major Long's expedition. Three miles above its mouth, on the opposite bank of the Missouri, in what is now Washington County, Nebraska, Major Long established himself September 7, 1819, and named the place "Engineer Cantonment." The site was half a mile above Fort Lisa.

15"Coupee a Jacques, where the river has found a new bed and abridged a circuit of several miles." (Coues ed. Lewis and Clark, $1: 71$.) There is a well-known point bearing this name farther up the 



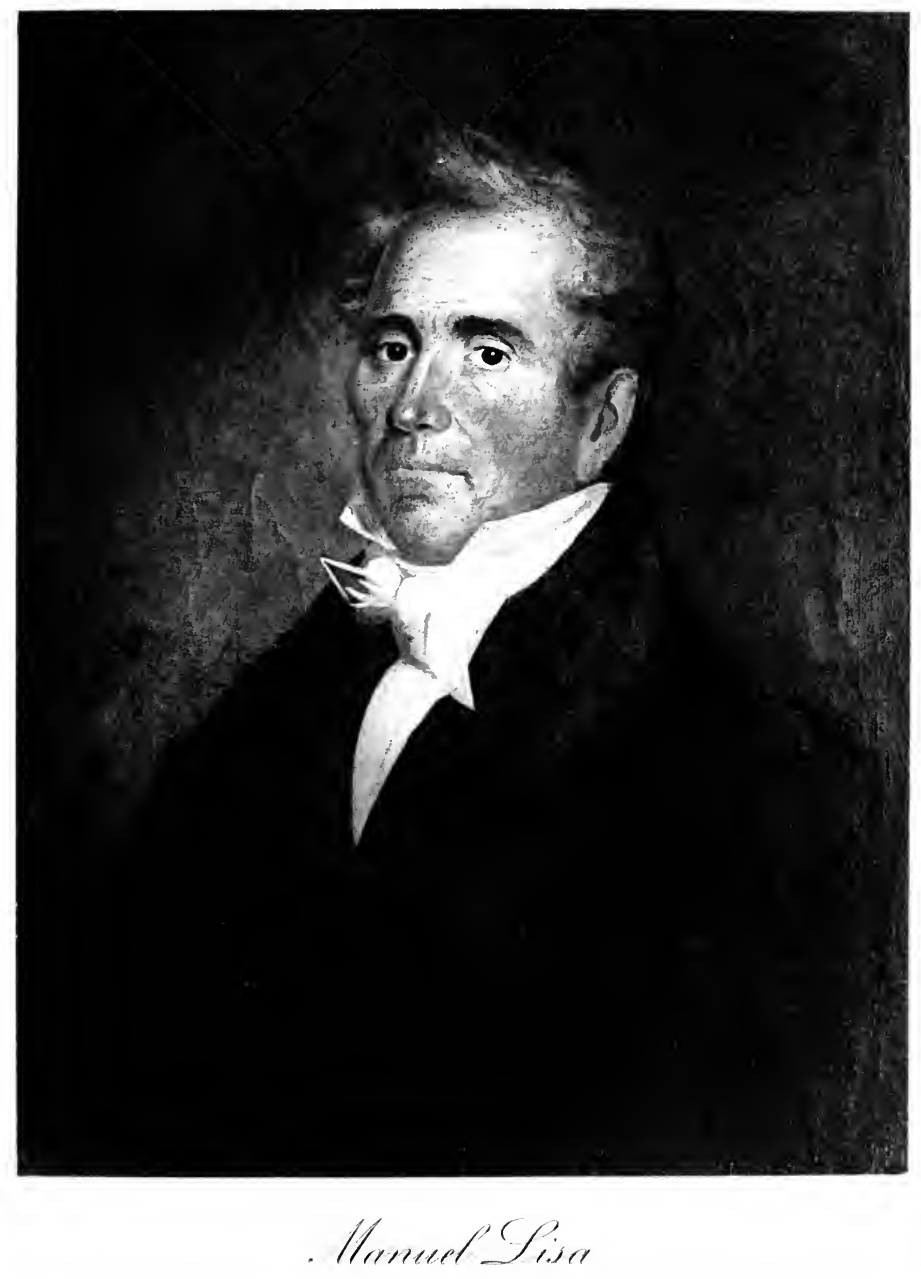


at 2 P. M. and council Bluff ${ }^{46}$ at 4 P. M. distance 20 Miles, Killed I Deer.

Thuesday, the 30 th fine weather and sailing we pushed on very well, and would have made considerable way if it had not been for the other Boat, were obliged to stop to make another steering Oar for her, during which time our hunters killed 3 Deer, distance 27. Miles.

Wednesday, the I of July. fine weather and fine sailing at 3 P. M. passed Soldier River, ${ }^{17}$ Missouri very crooked, no hunters out, distance 34 Miles, saw some Elk.

Thursday the $2 \mathrm{~d}$ fine weather head wind but good water made good way, cordelling all Day, camped at the Mouth of little Sioux River $^{48}$ distance 23 Miles, Killed 4 Deer I Duck.

friday. the $3 \mathrm{~d}$ of July. fine weather and light

river and it is shown on the Missouri River Commission map as being opposite St. Helena, in Cedar County, Nebraska.

${ }^{10}$ Council Bluffs. This name was given to these bluffs by Lewis and Clark, who held at this place, in 1804, an important council with the chiefs of the neighboring tribes. The first United States military post west of the Missouri River was built here by a detachment under Col. Henry Atkinson, in 1819. The fort was christened Atkinson for its founder, and was so known to the Government, but locally it seems to have been called Fort Calhoun. There is a town near by now known as Calhoun, in Washington County, Nebraska. Council Bluffs is the name of a flourishing city in Pottawat tamic County, Iowa.

47Soldier River is marked Rivière des Soldats on Perrin du Lac's map, and Soldier's River on the Missouri River Commission maps. It flows through Ida, Crawford, Monona, and Harrison counties, Iowa.

4The Little Sioux rises near the source of the Des Moines, flows in a southwesterly course and into the Missouri about midway between Sioux City and Council Bluffs. It was called by the French Petite Riviere des Sioux. 
favorable Winds in the forenoon., at I P. M. passed Coup Loysele, ${ }^{49}$ distance 18 Miles.

Saturday the 4th of July., we had ourselves prepared to salute the Day, which gave Birth to the Independence of the United States, put a Salute from Heaven prevented us, a thunder storm arose at 2 in the Morning and the Bank of the River where we camped fell in upon us momently. Mr Manuel Lisa was nearly drowned in his Bed, and we had to run off., rowing and poling all Day, about Sunset a favorable wind sprung up and carried us several Miles, were obliged to leave a large Buck and an Elk which our Hunters had killed behind, camped at Black Birds Hill, ${ }^{50}$ distance 15 Miles.

Sunday the 5 th fine weather at 8 A. M. came to a Channel ${ }^{51}$ which we entered, in hopes

${ }^{19} \mathrm{La}$ Coupée d Loiselle. Brackenridge says: "This name originated in the circumstance of a trader having made a narrow escape, being in the river at the very moment that this cut-off was forming." The trader here referred to was probably Regis Loisel, who had a trading-post on Cedar Island.

${ }^{60}$ Blackbird Hill was named for a celebrated chief of the Omahas, who was buried on this hill. Brackenridge says that he was buried sitting erect on his horse, and chose this spot as the place of his interment, so as to enable him to see the traders as they ascended the river. This chief, he says, was famous among all the nations in this part of the world, and his grave at a late day was still held in superstitious awe. His possession of some arsenic, received from a trader, was the secret of his greatness. With this he made his propheeies of death against those who opposed him come true with a seemingly magic precision. Blackbird died about 1803 . This bluff, with the mound surmounting it, was at one time one of the curiosities of the Missouri and a prominent landmark, but the mound has now almost disappeared.

61Th:s is an illustration of the shifting of the river bed. While apparently the first channel attempted was an incipient cut-off, the other was the remains of a portion of 1 ts bed which the river had abandoned. 
to go through, to cut off 6-Leagues of the River, but were disappointed, having ascended within I50 yard toward the head of it, the Water became so rapid as to endanger our Boats to sink, we returned with Difficulty, at a little Distance found another, which was also tried, but to our Sorrow found not Water enough at the head and returned took the old Route, and were stopped at 5 P. M. by a Thunderstorm, distance 15 Miles.

Monday. the 6 th rained very hard last night, cleared up and we made best of our way at. 4. oclock in the Morning had a few Squalls and rain, at $8 \mathrm{~A}$. M. a fair wind arose and had fine sailing for several hours, the River very crooked had to row at times, at 2.30 M. P. M. passed Mohaw River, ${ }^{52}$ and opposite the Village at 4. P. M. 2 Men went to see if any Indians were there, they returned not being able to gett to the Village on $\%$ of Swamp and Musquitos, camped on a Sand bar, distance 30 Miles.

Thuesday, 7th started at Day break, cloudy, head wind and rain, in the afternoon passed floyds. River, ${ }^{53}$ Sun River ${ }^{54}$ and at dark Big Sioux River, ${ }^{55}$ distance 18 . Miles.

${ }^{2}$ Mohaw, Maha, or Omaha, as it is now called; a good mill stream in Dakota County, Nebraska. The Omaha Indians lived on this stream.

53Floyd's River was named to commemorate the death of Sergeant Charles Floyd, of the Lewis and Clark exploring party. Floyd died near the mouth of this stream on August 20, 1804, and was buried on the Bluffs, which also bear his name, just below the site of Sioux City.

${ }^{54}$ Now Perry Creek, named for Robert Perry, who settled on it in 1849. It is in Sioux City, Iowa.

${ }^{85}$ The Big Sioux heads near the source of the Red River of the North. 
Wednesday the 8., Head wind and Rain, hard work all Day toward Evening had some sailing, camped on a Sand bar, ${ }^{56}$ Musquitos in Clouds. distance 18 Miles, Killed I Deer.

Thursday the 9th departed early, took a Channel which we found shut up, and lost the Morning, at Dinner several Hunters went out to make fires to give Notice to the Indians of our approach, passed a small River named Iowa, ${ }^{57}$ in the afternoon had fine sailing, distance 24 Miles, Killed I Deer.

friday the roth Head wind and strong Current all Day. The River very high, left 5 Hunters on shore,-distance ro Miles Killed I Deer.

Saturday the II, Rain \& cloudy Morning, at 8 A. M. cleared up with a fair wind, took in our hunters, set sail, at noon waited one Hour for the little Boat passed Vermillion River ${ }^{58}$ on the North side and at 5 P. M. the River

It meets at its mouth the States of South Dakota, Nebraska, and Iowa, forming the boundary between Iowa and South Dakota. The river is called on Nicollet's map Tchankasndata, which name is said to mean that the river is continuously wooded. The upper part was also distinguished as the Watpa-ipak-shan, or crooked river, and by the French as La Riviere Croche.

${ }^{66}$ Lewis and Clark camped on this sand-bar August 18, 1804, and sent a detachment under Sergeant Ordway to the Omaha village with an invitation to the Indians to join them in council and smoke the pipe of peace.

${ }^{87}$ Ayoway Creek on Nicollet's and Missouri River Commission maps, but Iowa on present maps. It is in Dixon County, Nebraska, just above the 830 th mile point of the Missouri River.

${ }^{68}$ Vermillion River, called by Lewis and Clark the Whitestone River. Indian name was $W$ assisha, literally meaning "smoky earth." It runs through Clay County, South Dakota, and the town of Vermillion is at its mouth. Vermillion is on the north side of the Missouri River. 
$\operatorname{Arck}^{59}$ on the South side waited for the little Boat and had to camp before Sunset to lett her come up with us, lost some elegant sailing on her account-distance 33 Miles.

Sunday, the r2th. set sail early in the Morning and by all appearances were to make a good Days Journey, but the other Boat not keeping up with us we were obliged to wait several hours for her, and lost considerable in making way, the wind changing at noon, at 8 A. M. passed River Jacques, ${ }^{60}$ Missouri still very high, distance $18 \mathrm{M}$.

Monday the 13 th, head wind and hard Current, rowed, poled and cordelled all Day, several hunters went out they returned at 4 P. M., no game, but had seen many fresh track of Elk, waited 2 hours for the other Boat at 5 P. M. made Island of Bonhomme ${ }^{61}$ and

${ }^{\circ}$ The Arck is referred to in the Journals of Lewis and Clark as "a small creek called Petit Arc, or Little Bow, and a short distance above it an old village of the same name." Nothing remained of the village then but a mound about four feet high. It was built by a Maha (Omaha) chief named Little Bow, who, being displeased with Blackbird, seceded with 200 followers and settled at this spot. The Indian name of this creek is Hopa-wazhupi. It is the present Bow Creek in Cedar County, Nebraska. Vermillion Post, also known as Dickson Post, was established prior to 1835, opposite the mouth of Bow Creek in Clay County, South Dakota.

${ }^{0} \mathrm{Jacques}$, or James River, as it is now called, rises in a prairie just south of Devil's Lake in Wells and Foster counties, North Dakota, and flows nearly due south into the Missouri. The town of Yankton, South Dakota, is just above its mouth. The French called this river Rivière a Jacques.

'Bonhomme is a large island between Bonhomme County, South Dakota and Knox County, Nebraska. There is also a town bearing this name in South Dakota. The journals of Lewis and Clark, as well as Brackenridge, mention the ruins of an "ancient fortification" on this island. They were really natural formations, being simply sand 


\section{Ponca Country ${ }^{62}$ we had flattered ourselves to meet some Indians or Buffaloe but were disappointed, by this time we had passed the Countries of the following Nations, Little and Big Osage, ${ }^{63}$ Mahas, ${ }^{64}$ Soto, ${ }^{65}$ Yenctons $^{66}$ \&}

ridges formed by the river-the banks are low and subject to overflow. (See "Lewis and Clark and the Antiquities of the Upper Missouri River," by T. H. Lewis, in Amer. Antiq. and Orient. Jour., Sept., 1891, p. 288.)

62The Poncas of the Siouan family. In historic days they, together with the Omahas, Kansas, and Osages, formed a single tribe, dwelling, in the Ohio Valley near the Wabash River. After the migration westward and the separation which followed, the Poncas located near the mouth of the Niobrara. "In physical characteristics and in tribal customs the Poncas resembled their kindred, the Omahas. They had been oppressed through many years by the Sioux, and reduced by the smallpox, until when the traders came they numbered but little more than 200 souls. They were always on friendly terms with the whites; and a regular trading-post was maintained in their territory." (Chittenden, History of the American Fur Trade of the Far $W$ est.) The exclusive right to trade, for ten years, with the Poncas had been given by the Spanish Government to Jean Baptiste Monier, of St. Louis, in consideration of the fact that he had discovered and pacified that tribe in 1789. The Poncas had a reservation in Indian Territory and one in Nebraska. In 1906 their total population was about 833 . Their lands have been allotted to them in severalty.

'The Osage Indians were the most important of the southern Siouan. They were also the first in the Missouri Valley to have a regular trade with the whites. On Father Marquette's map, 1673, this tribe is located on the Osage River. About the beginning of the eighteenth century a division was made in the tribe, the Great, or Big, Osages going farther up the Osage River. This branch became known as Pe-he-sithat is to say, "campers on the mountains"; and the Little Osages as U-tseh-ta, or "campers in the lowlands." Later there was another division, known as the Arkansas Osages. This separation was due to Manuel Lisa's obtaining from the Spanish Government, in 1796, a monopoly to trade with Osage Indians. For twenty years previously this monopoly was under the control of Pierre Chouteau, who had great influence with the Osages. After Lisa secured this exclusive privilege, Chouteau induced the best hunters of both the Big and Little Osage clans to go with him to the Verdigris River in Arkansas, where he had the trade privilege. When General Pike went up the Osage River in 1806, he found the principal Osage villages near the junction of the Marmiton and the Little Osage River. There was also a village on the Marais des Cygnes, a few miles from the present town of Papinsville, Bates County, Mo. In 1815 the Osages began moving westward from their 
Kanzas, this Morning Immel \& Lorimier ${ }^{67}$ went a head by Land, all hunters went on the Island, but Killed but I Elk, two of them camped on the N: Side and the Boats on the South Side of the Island, distance I 8 Miles.

villages in Bates and Vernon counties and located on the Neosho. In January, 1823, there appeared in the Missouri Intelligencer the following: "The Osages of the Great nation contemplate abandoning their village on the Osage and intend removing next spring to the Arkansas in the neighborhood of the Little Osages. In consequence of this the Harmony Missionary Society, established on the Osage River not far from the Missouri, are removing across to the Arkansas."

The Osages were a brave and warlike people, and usually at war with the neighboring tribes. Although generally friendly toward the whites, the Santa Fe traders found them undesirable to meet, as they never hesitated to plunder and kill small trading parties.

64The Omaha Indians (usually called Mahas), one of the tribes of the great Siouan family, formerly lived on the Mississippi River, and constituted at one time one of the most powerful tribes of that stock. They lived for a period in Iowa, ranging as far north as the pipestone quarry, now the town of Pipestone, Minnesota. They were driven back by the Dakotas, and after separating from the Poncas they settled on Bow Creek, in Nebraska. Lewis and Clark found them on the westerly side of the Missouri, a little south of Dakota City, Neb., and they numbered then less than 600 , having been decimated in 1802 by an epidemic of smallpox. They were constantly at war with the Sioux. The population of the tribe in 1906 was 1,228 . This tribe is among the most civilized of the Indians.

${ }^{65}$ The Otoes belong to the Siouan tribe, and lived on the Missouri and Platte rivers for many years. In 1880 they were given reservations in Indian Territory. Tradition has it that in ancient times they lived about the Great Lakes under the name of Hotonga, migrating to the southwest, in pursuit of buffalo; later they divided into various tribes, known as Winnebago, Iowa, Missouri, and Otoe.

The Yanktons lived in the southern portion of the Sioux territory along the Missouri tiver in the valleys of the James, the Vermillion, and the Big Sioux, and even as far east as the headwaters of the Des Moines. They numbered about 1,000 people. They were the least troublesome of all the Sioux tribes and gave the traders comparatively little annoyance. Posts were maintained at different times for their convenience at the mouth of each of the tributaries of thc Missouri mentioned above. (Chittenden's History of the American Fur Trade.)

The Yankton and Yanktonais tribes were no doubt originally one group. (Hodge's Handbook of American Indians.)

${ }^{67}$ Louis Lorimier, born in 1785 near Cape Girardeau, Missouri, was the son and name-sake of the first settler and commandant of the 
Thuesday. the I4th fine weather head wind and hard water at $7 \mathrm{~A}$. M. took in our hunters they had killed I Elk I Deer. had to stop again at $9 \mathrm{~A}$. $\mathrm{M}$. to arrange another Mast for the other Boat and fix the old Rudder, crossed the River where we found some fine Cedar for the Purpose, stayed all day unloaded and loaded, put up the Mast and Rudder, camped and made this Day 4 Miles distance Killed I Deer.

\section{Wednesday July 15, made an early start and} good way at $9 \mathrm{~A}$. M. met the Company Boat coming from the Rees ${ }^{68}$ with Peltries, Papin ${ }^{69}$ and 5 Men. Mr. Manuel Lisa thought proper

Post of Cape Girardeau under the Government of Spain, and Charlotte Pemanpieh Bougainville, a half-blood Shawnee. The Lorimiers, the elder a native of Canada, were undoubtedly descendants of Guillaume de Lorimier, a native of Paris who came to Canada in 1695. Louis Lorimier, Jr., married, October 14, 1816, Margaret Penny, granddaughter of Anthony Bledsoe, and lived on a farm not far from Cape Girardeau. He was appointed, by President Jefferson, to the United States Military Academy, July 17, 1804, and was graduated November 14, 1806. On January 20,1808 , he was promoted to the rank of second lieutenant, and served on the western frontier until December 31 , 1809 , when he resigned. In 1816 he was a trader among the Shawnees and Delawares on the Castor River near Bloomfield, in what is now Stoddard County, Missouri, succeeding his father in the trade with the Indians. He died on his farm in 1832 .

Arikara, the accepted spelling, common!y called the Rees and Rickarees. They belonged to the northern group of the Caddoan linguistic family. "In 1770 French traders established relations with the Arikara, below Cheyenne River on the Missouri. Lewis and Clark found them living in three villages between the Grand and the Cannon Ball rivers, and found them disposed to be friendly to the United States." (Hodge's Handbook of American Indians.) About the beginning of the nineteenth century they became the allies of the Mandan and Hidatsa Indians, and in 1880 joined these tribes on their reservation near Fort Berthold. Twenty years later they became citizens of the United States. In early days they lived in earth lodges and cultivated the soil. The remains of their fortified villages were found by early travellers on the Missouri from the mouth of the Teton to the Mandans. There is an interesting account of this tribe in the Journal of Jean $B$. 
to take her back again having not sufficient Loading to defray the expense, passed River Luipere $^{70}$ and another small River, ${ }^{71}$ in the afternoon Squalls and Rain, camped 3 Miles below Leauquicour River, ${ }^{72}$ distance I6 Miles.

\section{Thursday 16 July, rained all night, and cleared}

Trudeau among the Arikara Indians in 1795 (Mo. Hist. Soc. Col. 4:9).

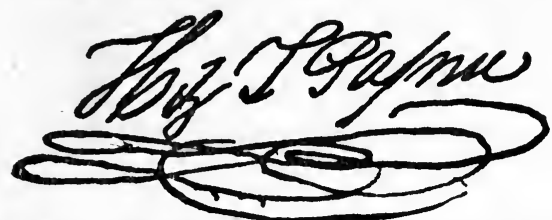

60HYPOLITE LEBER

PAP1N, familiarly known as Leber Papin, was born in St. Louis, December 24,1787 , being the third son of Joseph M. and

Marie Louise (Chouteau) Papin. On July 14, 1815, he married Josephine Loisel, daughter of Regis Loisel, fur trader and merchant, who had a trading-house on an island in the Upper Missouri River, at a place which became known as Fort aux Cedres. Loisel received from the Spanish Government a grant of 150,000 arpents at that point.

Ten children were born to Leber Papin and his wife; namely: $\mathrm{Hy}$ polite; Joseph L.; Pierre M.; Theodore; Raymond; Eugene; Edmond; Louise, who married Eugene Dupré; Emilie, who married James C. Waugh; Zoe, who married Edward N. Tracy; and Josephine, who married Robert C. Grier.

Leber Papin, with his brother Sylvestre, was engaged in the manufacture of hardware and fire-arms for the Indian trade, in preparation for which his father had sent him to Philadelphia to study the methods of the factories from which the trading companies of St. Louis had theretofore drawn their supplies. He furnished the American Fur Company and the Superintendent of Indian Affairs at St. Louis with tools and equipment for many years. The factory was on Main and Pine Streets, which was closed by Leber Papin, after the death of his brother Sylvestre. Leber Papin then retired to his farm, where he died December 20, 1842, leaving a large fortune for that period. Many of his living descendants are representative St. Louisans, as he was in his day.

70White Lime Creek of Lewis and Clark's map, and Lost Creek of the Missouri River Commission map.

'White Paint Creek of Lewis and Clark; L'Eau qui Monte of P. du Lac; Wasiska of Nicollet. It is now known as Bazile Creek. It flows into the Missouri in Knox County, Nebraska.

${ }^{32}$ L'Eau qui Court ('iuicourre- "rapid water," "running water"), now called the Niobrara, has its source in eastern Wyoming about twenty- 
up at Sunrise at 8 A. M. passed Leauquicour River very high and full. Mess Sanguinett ${ }^{73}$ \& Bijou went out to make fires as we expected the Indians soon to meet, camped opposite an Island ${ }^{74}$ not far from Ponca River, ${ }^{75}$ distance 18 Miles Killed I Deer.

friday the $\mathrm{I}$ 7, a fine Morning the Mackina Boat took 5 hunters to the Island and we continued our Route passed Ponca River, cordelled on the South Side along the Hills till Dinner, the Boat came up and brought I Deer I Beaver cordelled all Afternoon distance I7 Miles.

Saturday 18 , cloudy about 8 A. M. a fine favorable wind took us and we had good sailing untile 2 oclock P. M. when we discovered 3 Lodges of Sioux Indians ${ }^{76}$ and found Immel

five miles north of Fort Laramie, and flows easterly across northern Nebraska. The current, as its name implies, is very rapid.

${ }^{73}$ For a sketch of Charles Sanguinet, fils, see Appendix.

"Pawnee Island, in Knox County, Nebraska. The camp of this day was probably near Chouteau Bluffs in Bonhomme County, South Dakota.

76Ponca Creek, a prairie stream rising in eastern Tripp County and running north of and parallel with the Niobrara. It derives its name from an Indian tribe which had a fortified village on this river for some time. They subsequently resided with the Omahas.

${ }^{76} T$ ie Sioux, or Dakotas, belong to the Siouan family, the most populous linguistic family, excepting the Algonquian, north of Mexico. The word Sioux is an abbreviation of Nadowessioux, a French corruption of Nadowe-is-iw, the appellation given them by the Chippewas. It signifies "snake," "adder," suggesting "enemy." When the French traders first met them, in the latter part of the eighteenth century, their country embraced what is now the State of South Dakota, with contiguous territory all around its borders. Their wanderings extended far beyond their own lands. This tribe was among the most warlike of the western tribes, and, although they at no one time exceeded 15,000 souls in the Missouri Valley, they were everywhere 
\& Lorimier, the Chief of them LeNez ${ }^{77}$ traded with us 32 Beaver 3 Otter 2 Robes 13 Bladders of tallow and upwards of $300 \mathrm{lb}$. Dried meat, camped I Mile above them, Killed I Deer distance 24 Miles.

Sunday the 19th fine Morning about 7 A. M. we took in 2 Sioux who had been hunting, belonging to a band on white River, ${ }^{78}$ gave us a buffaloe tongue and stayed on Board all Day, our hunters went in search of Buffaloe but found none, passed Little Cedar Island, ${ }^{79}$ distance 18 Miles.

Monday the 20 , set 'sail at 4 in the Morning with a fine wind the Indians left us, sailed till Io A. M. when the wind changed and blew hard a head, at 4 P. M. met with a Sioux Chief called the Sleeper ${ }^{80}$ and 20 Soldier had some talk and camped with them, distance I 5 Miles.

held in terror by their enemies. They were men of great physical powers, and great hunters.

The three important divisions of the Sioux tribes in the Missouri Valley were: the Yanktons, the Yantonais, and the Tetons. When Luttig mentions the Sioux Indians or chiefs, he doubtless refers to one of these branches. During the War of 1812 some Sioux were on the point of joining the British forces against the United States.

"Le Nez was known by western Sioux as Pasu Ksapa, and was prominent in the same way that "The Sleeper" was. (Dr. A. McG. Beede, Missionary at Fort Yates, North Dakota.)

${ }^{78}$ White River, or White Earth River, rises in the northwestern corner of Nebraska, south of the Black Snake Hills, enters South Dakota, and, running easterly, empties into the Missouri in Lyman County. The route of travel between Forts Pierre and Laramie was through the valley of this river.

79Little Cedar Island in Gregory County, South Dakota. The Missouri Fur Company had a trading-post here, which was destroyed by fire in April, I810.

w“'The Sleeper,"Istinhmunma (meaning "to possess the mystic gift"), 
Thuesday the $2 \mathbf{I}$, departed at Sunrise as also the Indians we stopped at a small River ${ }^{81}$ where 4 Sioux Chiefs came to us, the Black Sky, Black Buffaloe, ${ }^{82}$ Big Horse ${ }^{83}$ and Crooked hand, ${ }^{84}$ we had Council and they informed Mr Manuel Lisa, that at present they had nothing to trade, but would have plenty next fall Immel went with them to their Village, 3 Chiefs and 2 young Men remained to fix on a spot for a trading house they went with us across the River to the North Side I Mile below where we had camped, laid out the house for Mr. Bijou ${ }^{85}$ who was to remain to trade with the Yentonas, Tetons ${ }^{86}$ and Shaunee, ${ }^{87} \mathrm{Mr}$ Manuel presented the Chief with Io Carrots Tobacco and some Powder and Ball they were seemingly well contented, Killed I Buffaloe and the Indians brought also some fresh Meat.

a Teton Sioux Indian. He was an Itancan, but to what extent he was a "chief" is hard to say. This Indian was conspicuous among Western Sioux, and has been frequently confused with the Minnesota "Sleepy Eyes.". The Sioux Indians frequently sent out emissaries to other tribes, on various pretexts, but as spies really. Some went as beggars, pretending that their people were starving and that they left in an effort to keep alive; others claimed to have been unjustly ostracized. "The Sleeper" seems to have been a master spy. (Dr. Beede.)

81This small river is the Shannon Creek on Clark's and Maximilian's maps. It was probably named for George Shannon. It is now called Rosebud Creek, and is near Rosebud Landing, Gregory County, South Dakota.

${ }^{82}$ Black Buffalo, a Teton Sioux, died in July, 1815 , at Portage des Sioux, St. Charles County, Missouri, while attending the Peace Treaty Council at that place. At the request of Gen. Clark he was interred with military honors. The funeral oration delivered by the chief, Big Elk, was a touching and eloquent one. Black Buffalo was a man of considerable influence. He was the principal chief with whom Lewis and Clark counciled at the mouth of the Teton, September 25 to 28, 1804, leading, after some difficulty, to the establishment of friendly 


\section{Wednesday the $22 \mathrm{~d}$ rose early, all hands except some lazy Rascals under pretence of being}

relations. In 1807 he was in the Arikara village, and no doubt took part in the attack on Lieut. Nathaniel Pryor's party, which was escorting the Mandan chief Sheheke back to his village. Black Buffalo was dangerously wounded in this skirmish. At the head of a party of Dakotas he met the Astorians at Big Bend in 1811 and protested against the carrying of arms to the Arikaras and Mandans, with whom his tribes were then at war. Manuel Lisa found him a powerful influence in the way of keeping the Dakotas friendly with the United States during the War of 1812 , and at the close of the war brought him down to Portage des Sioux.

${ }^{83} \mathrm{Big}$ Horse was an Oglala chief of the same family as the two wellknown chieis called "American Horse," but whether he was the father or uncle of the elder American Horse, or a remote kinsman. I am unable to say. He was prominent among Indians during the times when the road was being forced, with little progress, from the Platte River northwest. (Dr. Beede.)

${ }^{84}$ Crooked Hand. This man might have been Bras Casse or Broken Arm, who was in council with Gen. Pike in 1805 . His Indian name was Wah-kan-tah-pay, and he was living in 1825 at his village near Le Sueur in Minnesota.

Dr. Beede says he has often heard Crooked Hand mentioned as a sort of mentor of Inkpe Luta, though he did not participate with him in the Spirit Lake Massacre. Every ambitious youth had a sort of mentor in some one particular man of his voluntary choice, who more or less shaped his mind and career; and Crooked Hand was thus the mentor of Inkpe Luta (a somewhat misrepresented and misunderstood man), who was well known by many Western Sioux. He was an Itancan, but it is difficult to say whether or not he was a "chiet." $\mathrm{He}$ was said to have been an expert bowman.

${ }^{85}$ Bijou's trading-house was doubtless in the vicinity of the present Bijou Hills post-office, in Brulé County, South Dakota.

*The Teton Sioux were a very important division of the Sioux, and dwelt mostly west of the Missouri, covering the country as far west as the Black Hills and the North Platte, wandering north and south from the Pawnee country to the Mandans. These Indians were very troublesome in the early days of the fur trade. and were known as the pirates of the Missouri River. In later years they became friendly with the whites and gave the traders very little trouble. There were several bands of the Tetons, viz.: the Bois Brulés, who lived on both sides of the Missouri near the mouths of the White and Teton rivers; the Sans Arcs; the Blackfeet; the Minneconjous; the Two Kettles; the Oglalas, who dwelt at the headwaters of the White and Niobrara rivers; and the Hunkpapas.

"The Saone Indians were a division of the Teton Sioux, comprising the Sans Arcs, Sihasapa, Ooheneonpa, and sometimes the Hunkpapa. 
sick went to work.-at 3 P. M. Immel returned with 2 young Indians, the Chief Black Sky had presented him a horse, he reported the Chiefs and warriors would be with us to morrow-he found upwards of 400 Lodges and plenty of Buffaloe in the Morning when he started from there he saw several Buffaloe enter in the Village, this Day raised part of the house, Killed I Deer, caught several Catfish and I Beaver.

Thursday the 23, early to work, but unfortunaly the house fell down when nearly raised, and had to go over the same work, catched 7 fine fish in the forenoon which provided a fine Dinner, at 5 P. M. a party of Indians came opposite which we crossed and found them to be all Boys about 30 in Number they came to give us a Dance, they were all neat and handsome clothed, more so then I saw the Sioux of the Mississippi, in the Evening they danced and we gave them some Biscuit and I Carrot Tobacco they brought plenty Meat with them and gave plenty to the Boats.

friday the $24^{\text {th }}$ finished the house, in the afternoon sent Mr. Bijou, Equipment on shore, the Indians went over the River, and $\mathrm{Mr}$ Manuel Lisa gave the Chief black Buffaloe

They were first mentioned by Lewis and Clark, and, under the form Souon-Teton in Clark's manuscripts, where they are called "the people of the prairie." They made one of the twelve tribes of the Dakota, while the Souon were another. The Saone, under the name Sioune, joined the Oglalas in the treaty with the United States at the mouth of the Teton River, South Dakota, July 5, 1825. (Hodge, Handbook of American Indians.) 
the present from Government as also for crooked hand which Chief had promised to come over but did not come, he left it with Mr. Bijou to be given to him whenever he would arrive there left 2 hunters and $3 \mathrm{En}$ gagees with Bijou, discharged Bapt. Alar ${ }^{88}$ a good for nothing fellow.

Saturday the 25 , set sail at 4 in the Morning fair wind took 6 Indians with us which we landed and stood under sail till II A. M. when we took the Cordell for about I hour, dined, and set sail again, passed white River at 2 P. M. the [wind] slakening about 4 P. M. we took to Cordell again, Mr. Manuels Negro Boy Charlo went out the Boat to gett some grass or grasshoppers for a Prairie Dog which he had caught some days ago, he the Boy went upon the Hills unperceived, they are very high, he fell down a precipe into the River, the Man who was steering the Mackina

\footnotetext{
${ }^{88}$ Baptiste Alar. This name is spelled in American State Papers "Alary," "Alere," "Allard," and "Allare." In the archives of St. Louis City and County it has only two variations, "Alar" and "Allard." Baptiste Alar came to St. Louis in 1795 and settled in Florissant. St. Louis County. Prairie du Rocher was probably his former home, as there was a Jean Baptiste Alard, senior and junior, in the census of that village in 1787 . In 1818 Alar was engaged by the American Fur Company as a boatman to serve for three years at Prairie du Chien. At the end of this period he returned to Florissant, bought some land, upon which he erected a home. He was living there in 1825 . He had two children-one named Julia, born December 11, 1816, whose mother was Julia Laviolette; and the other, John B.-by Catherine Laviolette. John B. Alar, Jr., married at Cahokia, April 28, 1818, Louise Desmarets, the daughter of Joseph and Julia (Lepage) Desmarets. In May, 1846, the public administrator of St. Louis took charge of the property of Jean Baptiste Alar, deceased. As no heirs were found, he property was paid into the State treasury in December, 1849.
} 
Boat saw it, and cried out to Mr Lewis ${ }^{89}$ (who was walking in the Rear of the Boats) to save the Boy but Mr Lewis unfortunately did not understand the men however saw something struggling in the water, but thought the Boy was a swimming, when the Men came towards him, they went to find the Boy, alas he was gone, he must have been stunned by the fall or otherwise would have saved himself, the River was not 4 feet deep, he drowned at 5 oclock P. M. we searched for him some time but the Current had swept him off, cordelled a little way, crossed to an Island, set out 3 hunters, at sunset the. Wind fair, set sail, took in our hunters, camped on a Sand bar the wind blowing fresh all night distance 30 Miles.

Sunday the 26 , set sail at 3 in the Morning, at 8 A. M. Immel \& Queenville ${ }^{90}$ went out to

ॠFor a sketch of Reuben Lewis, see Appenciix.

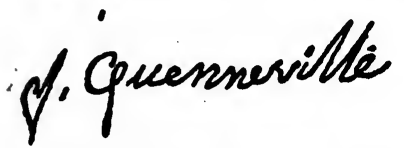

${ }^{90}$ Francois Quenneville lived in St. Charles, Missouri. In June, 1814 , he gave his note to Mr. François Duquette, to be paid upon his return from a trapping voyage. The next record I find of him is with the American Fur Company's Post in southwestern Missouri. He seems to have spent the remainder of his life in that section. He married Wihethtanga, an Osage woman, and of this marriage there is record of the following children: François, born about 1819; Pierre, born about 1822, baptized at Harmony Mission, August 21, 1827; Angelique, born October 10, 1826; André, born about November 5, 1829, and baptized near Marais des Cygnes, June 9, 1830; and Elizabeth, who married August 10, 1840, at the American Fur Company's trading-post on the Osage River, Jean Baptiste St. Michel. There was a trapper of this name with the Spanish Company in 1794. As he was referred to as "Sieur Quenville," by Jean Baptiste Trudeau, there is no way of determining that he is the same man of this expedition. 
hunt and to visit his house were he lived last Winter, ${ }^{91}$ we came up with the house very fast, stopped a few Minutes the wind fresh in our favor, took in Immel, Queenville had run after some Buffaloe, we went pretty fast and were obliged to stop for Queenville, who was far behind we gave him signal, and embarked him, he had killed I buffaloe but we left the Meat, taking care of the wind at $\mathbf{I}$ P. M. made Big Bend, ${ }^{92}$ camped on the North Side.-Distance 36 Miles.

Monday the 27 th departed at 4 in the Morning a fresh wind sprung up and carried us out of the Bend, the wind slackening we had to take to our oars, at $8 \mathrm{~A}$. M. we set sail again and sailed till I I A. M., after Dinner Immel Lorimier and Greenwood went out the Boat to go by Land to the Rees. cordelled all afternoon, and camped at the point of Cedar Island, ${ }^{93}$ distance 21 Miles. Killed I Deer.

Thuesday the $28 \mathrm{th}$, set sail with a favorable wind at 3:30 minutes in the Morning, but the wind failing had to take to cordelling, last night

"Lisa called Immel!'s wintering place Fort St. Michel chez des Sioux. It is doubtful on which side of the river this trading-house was located, and therefore it may have been either in Lyman or Buffalo County, South Dakota. Lisa probably named it in honor of the patron saint of his efficient lieutenant, Michael (Michel) Immell.

${ }^{2}$ Big Bend was also known as the Grand Detour and the Great Bend. The camp of this night was in what is now Hyde County, South Dakota.

- $C$ Cedar Island is a name that was applied to various islands, miles apart, in this portion of the river. This particular one, near Cedar Creek, is indicated as "Cedar or Dorien Island No. $I$ " on the Missouri River map of 1895 . It was on this island that Regis Loisel built 2 four-bastion fort of red cedar in 1800 . 
caught 3 Beavers, Killed I Cabri ${ }^{94}$ Elks, distance 18 Miles.

Wednesday the 29 th head wind and clear, cordelling all day at 4 P.M. passed little Missouri River, ${ }^{95}$ killed I Buffaloe, 2 Deer, I Badger, distance 2 I Miles.

Thursday the 3oth fine weather but head wind, had to cordell all Day saw a band of about 50 a $60 \mathrm{Elk}, 3$ of them close to us in the River, but had no luck to Kill the Mackina Boat was gone a head with the hunters and did not come to our Camp that night, distance I8 Miles.

Friday the 3 Ist departed early cloudy and head wind cordelled all Morning at 7 A. M. met the Mackina Boat they had Killed 2 Deer and I fawn, crossed the River after breakfast the wind becoming very hard made very little way. Killed I Buffaloe 4 Deer, distance 12 Miles. This Morning we left our old she Cat at Camp, at breakfast I missed her, and Mr. Manuel sent a Men for the Cat, he returned in the Evening with the Cat to

\footnotetext{
"Cabre: goat or antelope, which the French call cabre. The antelope was unknown to science until Lewis and Clark discovered it, but it was not scientifically named until 1815. (Wheeler's Trail of Lewis and Clark.)

${ }^{95}$ The Little Missouri was later called the Teton, and now Bad River. The Sioux Indians called it Wakpa Chicha, meaning "Bad River." It rises just east of the Bad Lands, and flows through a section abounding in salt springs. For many years there was a trading-post at the mouth of this river, and it was one of the most important locations in the Sioux country. Fort Laframboise was built there in 1817 , and in 1822 the Columbia Fur Company had its principal fort, called Tecumseh, on the west bank of the Missouri about two miles above the mouth of the Teton, or Bad River.
} 
our great satisfaction this Remark may seem ridiculous, but an Animal of this kind, is more valuable in this Country than a fine Horse. Mice are in great Abundance and the Company have lost for want of Cats, several Thousand Dollars in Merchandize, which were destroyed at the Bigbellies station, there has not a night passed since our departure from Bellefontaine where I got that Cat, that she has not caught from 4 to ro Mice and brought them to her Kittens.

Saturday the rst of August last night caught 2 young Beaver, cordelled all Morning, still and very little Current at I0.I 5 min. passed Chajenne River ${ }^{96}$ very low at this time saw several Buffaloe, chased, but without Success, crossed the River, and cordelled along the Bluffs, at Dinner we stopt at some Bluffs above Chajenne River about 4 Miles, where I found plenty Iron Ore, and somewhat higher up signs of Salpeter. Distance 18 Miles Killed 2 Deer.

Sunday the $2 \mathrm{~d}$ some Rain fell last night, cloudy in the Morning, $6 \mathrm{~A}$. M. cordelling the little Boat joined us, they had meat of 3 Buffaloe, one Cow they found wounded with an Arrow, she came into their Camp. Distance 18 Miles Killed I Deer.

"Cheyenne River, Washte Wahpa-Dakota words, meaning "Good River," the antithesis of the river south of it. The main forks of the north and south branches of this river embrace the Black Hills proper. It flows eastward toward the Missouri, draining western South Dakota, and joins the Missouri in Stanley County, South Dakota. It takes its name from the Indians who lived upon its upper waters. 
Monday the 3 at 6 A. M. a Canoe with Garrow, ${ }^{97}$ the Interpreter, 2 Engagees and Goshe ${ }^{98}$ a Ree Chief came to us, they brought some Corn and a Letter from Immel at noon passing along a Bottom, we found a Mocassin tied to a tree in which we also found a Letter of Immel informing us they were well and would be at the Rees from thence in One Day. Distance 2r Miles, Killed 5 Deer.

Thuesday the $4^{\text {th }}$ headwind as usual, cordelling our Hunters went out this Morning and at dinner brought 3 Deer I Buffaloe 4 Ducks, passed Mauro River ${ }^{99}$ in the afternoon Killed I very large Buck. at 5 P. M. a heavy storm

${ }^{97}$ Joseph Garreau, probably a son of Pierre Garreau of St. Charles County, Missouri. In 1787, when twenty-three years of age, Joseph was engaged by Don Andres Fagot la Garciniere of St. Louis to hunt and trap on the Upper Missouri River. In January, 1795, he was at Red River with the North West Company. He seems to have remained in that country for the remainder of his life, for every traveler who has recorded his observations of that region has made mention of him. Lewis and Clark refer to him as "Mr. Garrow" and "Interpreter Garrow." Wilson P. Hunt saw him in I $81 \mathrm{I}$ and says that Garrow told him he had been with the Arikaras twenty years. Irving described him as a "French Creole, one of those haphazard wights of Gallic origin who abound the frontiers, living among the Indians like one of their own race." Beckwourth tells us of Pierre and his brother Antoine, and of their father, "who was a great man among the Indians." Major Kearny, in 1825 , speaks of him as an "old Frenchman who has been with the Arikaras for thirty-seven years." Maximilian and Larpenteur both mention him. Garreau married an Arikara Indian and his sons were for many years interpreters at Fort Berthold. South Dakota claims Joseph Garreau as the first permanent white settler in that State. The Missouri Fur Company's books show that he was engaged by it from August 4, 1812, to May II, 1813.

${ }^{98}$ Le Gauche, "The Left-handed," was the hereditary chief of the Arikaras. He was a fine-looking man, much above the average size.

${ }^{99}$ Mauro, Moreau River; named for a Canadian trader. Clark called it Sur-wa-carna, or "Park River," an Arikara name. On most maps it is given as Owl River. It runs parallel with the Grand River above and the Cheyenne below. 
arose and we had to lay by. at 6 P. M. 2 Skin Canoes met us, with Lorimier, Greenwood, Dougherty ${ }^{100}$ and Weir, ${ }^{101}$ it continued raining and we were obliged to Camp. Distance I 5 Miles.

Wednesday the $5^{\text {th }}$ cleared up in the Morning and we went on Cordelling, but had the good Luck to get fast 3 times, at Dinner our hunters brought I large Cabri and 2 Deer very fat, I Goose, pursued our Vojage and at 5 P. M. met 3 more hunters of the Company from the Rees, camped 3 Miles below Grand River.

\section{Thursday 6 th at 6 A. M. passed Grand River, ${ }^{102}$}

100For a sketch of Major John Dougherty, see Appendix.

${ }^{101}$ William Weir, probably a son of William Weir, a Revolutionary soldier of Scotch-Irish descent, and a brother of James Weir, one of the early settlers of Muhlenburg County, Kentucky. He was born at Fishing Creek, South Carolina, in 1787 , was of an adventurous spirit and left home at an early age to seek his fortune. He came to Missouri and enlisted with the Fur Company. He was one of the party who went with Henry across the mountains in the fall of 1810 , and upon their return to the Missouri he remained at one of the forts and continued in the service for a number of years. He was an active, efficient man, brave and skillful, and took rank with Dougherty and Colter. In 1818 he was appointed by the Territorial Legislature one of the commissioners to establish the county seat of Cooper County, and in 1820 he was charged with a similar duty for Cole County. In 1819 and 1820 , and perhaps for a longer time, he was justice of the peace in Moreau Township, Cooper County. In 1816 he married, and afterwards went to Crawford County, where he cleared a farm and made a home for himself and family. The spirit of adventure was too strong in him to allow him to abide contentedly at home, and he joined a trading party on a trip through Texas to Mexico. He died at his home in Missouri in 1845 , leaving ten children. One of them, John Weir, went to Texas in the '3os, and there did good service in helping to achieve the independence of the country. In 1853 he crossed the plains to California, and in $185^{8}$ he went to the Puget Sound country, where he spent the remaining years of his life, and where his descendants still remain. (Douglas ed. Three Years Among the Indians and Mexicans, St. Louis, 1916.)

${ }^{102} \mathrm{Grand}$ River was also known by its Arikara name, Weterhoo, 
Mr. M. Lisa had intended to build a fort here, but finding the Situation not eligible for a Fort, moved on and camped about 12 Miles below the Rees. Distance I 5 Miles.

Friday the 7 th had a little Wind in favor set sail and at 12 oclock $M$. arrived at fort, ${ }^{103}$ all Indians in Motion to a Number of abt 1200 souls, Mr. Manuel L- could not immediately go on shore, as he had his Leg strained this Morning when Jumping out of the Boat, and got very lame, a horse was procured and he went to the Village and held Council with the Principal Chief, the 2 other Chiefs did not come to Council and Jealousy reigned among them, about 2 P. M. the Women and Children who were about our Boats were called away to the Village, and in a few Minutes the Coast was clear, this was not a friendly Signal, and we prepared for the worst, after Dinner Mr. M. L- resolved to go to the Fort, he went with ro armed Men and sent for the Chiefs to explain their Conduct. when it appeared that Goshé had received his presents and they not, and further complained on Account of the Merchandize to be taken away from them to trade $\mathrm{Mr}$. M. L., came to an absolute Resolution and they gave up, they were satisfied to have a Fort built at the third point above their Vil-

or Wetarhoo. It flows through Harding, Perkins, and Corson counties, South Dakota; at its mouth is the Standing Rock Indian Reservation.

${ }^{108}$ This reference is doubtless to an Indian fort, as there is no record of a trading-post at this place. 
lage about I2 Miles distance. ${ }^{104}$ La Plume $^{105}$ the Chief of the $2 \mathrm{~d}$ Village received his Present and harmonie was restored, they traded some in the afternoon loaded the Peltries $\&^{2}$. and prepared for Morning, set a Volunteer Guard, though guarded, the Indians would pilfer every thing they could lay their hands on.

Saturday the 8th started early without trouble, several went by Land as also some Indians, Goshé and La Plume overtook us at noon, in order to stop us and not go too high from their Village ${ }^{106}$ but the Place where we were did not answer for our purpose pursued our Route, the Chiefs went back seemingly displeased, camped I 2 Miles above the Village, last night had our 2 Cats stolen.

Sunday the 9th of August started early and at 7 A. M. arrived at a beautifull Prairie Bluff with several Bottoms of fine timber around,

${ }^{204}$ Arikara villages. Luttig clearly indicates that the Rees' village was twenty-four miles above the Grand River. Dr. Doane Robinson says, however: "These villages were situated on the west bank of the Missouri about eight miles above the mouth of the Grand, in what is now Corson County, South Dakota. The river at this point runs from east to west, so that the villages were on the north shore." Trudeau, in 1795, was at the Arikara village near the Grand River. Lewis and Clark found this tribe occupying three village sites, which were within about four miles of each other along the river, between the Grand and the Cannonball rivers. They were then located higher up the river than formerly. Brackenridge visited them in 1811 , when they were eight miles above the Grand River, with a small creek separating two of the villages. In view of the shifting of their villages, it is rather difficult to precisely locate them at any one period.

${ }^{105}$ La Plume, Plume d'Aigle, probably the "Eagle's Feather" (Piaheto), who was the third chief of the Arikaras when Lewis and Clark passed the village in 1804 . The explorers named a creek in Corson County, South Dakota, for this chief.

${ }^{106}$ It was not unusual for the Indians to arbitrarily designate the spots where the trading-posts should be built. 
made Arrangement for our Camp and in the afternoon discharged the Boats, every Men happy to have come thus far of our Vojage. ${ }^{107}$

Monday the roth sent one Boat across the River with hands to cut timber for a Blacksmith Shop and Provision house all hands employed to fix a temporary Camp.

Thuesday the IIth, no news from the Village until noon when our Interpreter Garrow and a Soldier arrived, every thing quiet, they reported that a Skulking Big belly entered the Village at dark yesterday and Killed I Ree.

\section{Wednesday the 12, were informed a war Party had gone on, to fight the Bigbellies. ${ }^{108}$}

${ }^{107}$ Fort Manuel was situated close to the present line separating North and South Dakota. Gen. Chittenden says it was north of $46^{\circ}$ parallel, but he is mistaken in this. Dr. Doane Robinson, of the South Dakota Historical Society, locates it on the cape just east of Kenel post-office in Corson County, South Dakota, and says that he has been told of the remains of a post at that point. Dr. A. McG. Beede, missionary at Fort Yates, North Dakota, says the fort was near the mouth of a creek, about one-half of a mile down the river from Kenel. Maximilian mentions Lisa's trading-house among the Arikaras, "of which nothing now remains; though the place is still called Manoel Lisa's Fort." It seems to me that Doctors Robinson and Beede fairly agree with Luttig on this point, after summing up the distances of travel noted by him.

${ }^{108}$ Grosventres of the Missouri, as they were called by the French, and Minnetarees by the Mandans. The tribal name, however, was Hidatsa. For many years they were a migratory people, but finally settled in permanent villages like the Mandans. Close association with the Mandans caused them to adopt many of their customs. Their home was on the right bank of the Missouri, near the mouth of the Knife River. James, in his Three Years Among the Indians and Mexicans, says of them: "We found a manly, warlike, and independent tribe, who might well be called for their daring and enterprising qualities Gros Crurs, or "Big Hearts," instead of "Big Bellies." Alexander Henry describes them as being "a fierce and savage set of scoundrels, less sociable and affable than their neighbors, the Mandans." Under the name Hidatsa, the Minnetarees and the Crows were once united in a single sub-stock of the great Siouan family. 
Thursday the 13th Mr. M. Lisa had resolved to go up with a party to the Bigbellies to arrange Matters with them and bring down the Peltries, the Bigbellies having Killed 2 hunters and stole 26 Company horses, as also detained the Trader they had with them, he accordingly went this Morning at 8 oclock and 26 Men with him. At ro P. M. 60 Rees composing a War party arrived they requested something to eat, our hunters had just come in with 3 Buffaloe and I Deer, we gave them some Meat, and ferried them across the River, this Day cut timber for different Buildings, at the same time the Rees were crossing the River 8 Canoes hove in sight coming down with Meat, the men in the Canoes saw so many Indins crossing, took the terrors put their Canoes on shore and run off, both parties thinking they were Ennemies, as soon as the war party arrived on the other side they gave the Halloo and run in full Speed to the Canoes, finding nobody and seeing the Canoes belonging to their own Nation, they took some Meat and without searching for their friends went off, 2 hours afterwards 2 Indians appeared and ventured to come over to our side, on arrival we found them to be 2 Squaws the Men consisting of 2 Rees, 2 Panis, ${ }^{109} 2$

${ }^{109} \mathrm{Paw}$ nee Indians belong to the Caddoan family and called them ${ }^{-}$ selves Chahik-si-chahiko, "men of men." Hodge says that the name is probably derived from pariki, a horn, a term used to designate the peculiar manner of dressing the scalp-lock. In historic times the Pawnee tribes established themselves in the valley of the Platte. They had four distinct villages, the Grand Pawnee, the Republican Pawnee, the Tapage, or Noisy Pawnee, and the Skidi, or Pawnee Loup. In the latter years of the eighteenth century the Republican Pawnees moved 


\section{Chayenne, ${ }^{110}$ had run off, and left every thing behind them.}

Friday the 14th This Morning at one oclock were alarmed by the firing of a Gun, and heard the Dashing of Oars when to our Surprize we saw Mr. Manuel \& party returning, he having been informed by one of those Cowards who had run off from the Canoes, that all the white Men were Killed and that the Indians had crossed the River in our Boat

south to the north branch of the Kansas. These tribes were agriculturists, as well as hunters, having permanent villages. They were of splendid physique and great horsemen. The Pawnees were constantly at war with the neighboring tribes, never remaining faithful to any allies for any length of time. These Indians were greatly feared by the Southwest traders, as were the Blackfeet by the traders of the Northwest. It was this tribe that attacked the Chouteau-De Mun party as they were descending the Arkansas River in 1816. The party was forced to take shelter on an island just west of Hartland, in Kearny County, Kansas.

${ }^{110}$ The Cheyennes are of Algonquian stock, and were called by the Sioux Shahiyena, or Shai-ene, meaning "to speak a strange language." This tribe never called themselves Cheyennes, but Tsis-tsis. They lived before 1700 on the Mississippi, in what is now Minnesota. The first mention of this tribe in history is in 1680, under the name of Chaa, when a party of that tribe visited La Salle's Fort on the Illinois River. Later they moved to the banks of a branch of the Red River, in North Dakota, which thereafter became known as the Cheyenne River. Here they cultivated the land and built earth lodges. After some difficulties with the Sioux Indians, they were driven toward the Missouri, where they tarried for a short while. Some time afterwards they crossed the Missouri and took refuge in the Black Hills about the head of the Cheyenne River of South Dakota, where Lewis and Clark found them in 1804. In their journals they state that the Cheyennes were at peace with all except the Sioux, but that they frequently went on plundering excursions, stealing horses from the Spanish settlements. They were a fighting people, and, it seems, were almost constantly at war with the neighboring tribes. Until 1856 they were friendly to the whites, but from that time they were a terror to the border settlements, and gave the United States considerable trouble. Since about 1880 the tribe has been confined on two separate reservations: the Southern Cheyennes in Oklahoma, and the Northern Cheyennes in Montana. In I90I the lands of the Southern branch were allotted in severalty and these Indians are now American citizens. 
to Kill them also, supposed by the Sioux, Mr. M. L. alarmed on this Account returned immediately to Camp, finding however to his great Satisfaction the History of the Indian false, he remained till breakfast and pursued his first Intentions, last night about 40 Indians camped with us they were gathering Cherries and other fruits about the Country finished the Blacksmith shop and Provision house, caught 8 fine Cat fish.

Saturday the 15 th This Morning cloudy, some hunters went out, no Meat at home, caught 8 Cat fish, Rain at intervals.

Sunday the I6th hard Rain last night, cleared up in the Morning and all hands went for timber, at 5 P. M. our hunters returned with Meat they had Killed I I Buffaloe, caught II Cat fish, and Killed I I Ducks.

Monday the I7th, clear, all hands cutting timber and making Hay, caught 15 fish, and Killed 5 Ducks.

Thuesday the I8th all hands employed as yesterday. 2 Hunters went out for Buffaloe, caught 4 fish.

Wednesday the 19. the hands employed in Work as yesterday at noon our hunters came in with Meat of 2 Cows. Killed Io Ducks.

Thursday the 20 , North wind \& cold, cloudy in the forenoon hands at work as yesterday, fine afternoon Mr. Lewis caught a Prairie Dog, caught 4 fish, Killed I Pheasant. 
Friday the 2 Ist, clear and hard wind, still at work cutting timber and making hay. Killed 6 Ducks. Mr Lewis's Prairie Dog was nearly Killed by one of our Dog who brocke the Chain and run off with him.

Saturday the $22 \mathrm{~d}$, clear and windy, the same Work going on. at noon Goshé and $\mathrm{Nez}$ Corbain ${ }^{111}$ a Yentonas Chief arrived with four Sioux, at 6 P. M. our hunters came in with Meat of 5 Cows. this Day blew a very hard Gale from the South west. Killed 28 plover and 4 Ducks.

Sunday the $23 \mathrm{~d}$, clear, wind west $\mathrm{N}$. west, the same work, at noon La Plume paid us a Visit, dried some Meat very warm.

Monday the 24th clear, wind west, 3 hunters went out being informed the Buffaloe was near by a party of Indians which had been hunting at ro A. M. I2 Canoes arrived with meat they made a present of 18 Tongues and went off at noon caught ro fish.

Thuesday the 25th cloudy and disagreeable, hands at work as usual.

"Ner, de Corbeau, literally "Raven's Nose"; called by the French "Roman Nose," and by the Indians "Wind That Walks." He was for a time second chief of the Sioux, but, being the cause of the death of a trader in 1799 , he voluntarily relinquished that dignity. When Gen. Pike met him in 1806 , he requested to be given up to the whites. $\mathrm{He}$ then determined to go to St. Louis and deliver himself up, where he said they might put him to death. As the crimc was committed long before the United States assumed its authority, and as no law of theirs could affect it, Gen. Pike conceived "it would certainly be dispunishable now." Nez de Corbeau was considercd one of the most intelligent of his nation, and was soon reinstated in his rank. Pike commissioned him First Chicf of the nation. 
Wednesday the 26 , cloudy and cold, at 7 A. M. Mr. Manuel Lisa returned with part of the Men from his expedition, the Rest of the Men were coming by Land with the horses which he traded and given up by the Bigbellies, the head Chief Borne ${ }^{112}$ refused to give up the stolen horses, Mr Manuel cleared the trading of Peltrie and Goods and took off the whites, at I P. M. Grey Eye ${ }^{113}$ (Ree Chief) arrived with 100 Men from a war tour, they had not Killed nor even seen an Ennemy, in the Evening a larger Party passed by with two Scalps which they carried before them in triumph at dark some more arrived and camped with us.

Thursday 27, clear and fresh, the Big white, ${ }^{\mathbf{1 1 4}}$ Mandan Chief arrived, with several of his ${ }^{112}$ Le Borgne, or "The One-eyed," a chief. This Indian is described by Brackenridge and Alexander Henry, from whom we learn that he was a giant in stature, having huge limbs, gigantic frame, bushy hair, and only one eye, from which there flashed fire and penetration,-all of which gave him the aspect of a savage brute. His aquiline nose was of great size and his mouth wide. His countenance denoted a brave and enterprising warrior. He was the great chief of the Minnearees and swayed with unlimited control all the villages. Lewis and Clark presented him with their swivel gun, on their return from the Pacific. At the time Luttig saw him he was about 5 I years of age. Le Borgne is supposed to have been killed by a rival chief, Red Shield.

${ }^{113}$ Grey Eyes, an Arikara warrior, was a cunning and unscrupulous Indian. He was not the hereditary chief of this tribe, but owed the position of chieftain to his ability, courage, and arrogance. He kept his people in terror of him. When Hunt's party stopped at the Arikara village and asked Left-handed, who was the hereditary chief, whether he could supply the party with horses, Grey Eyes answered the question by saying that they could easily steal more, if there was not enough. Grey Eyes seems to have been the principal agitator in the fight against Gen. Ashley's party, and was killed, in leading the attack on August 10, 1823, by the first shot from the artillery under Lieut. Morris of Col. Leavenworth's command.

${ }^{14} \mathrm{Big}$ White (Sheheke, or Shehaka). In recognition of his rank as Chief of the Mandans, he was given a medal by Lewis and Clark in 
Bravos and family, to pay a visit, he had a few Robes which he traded, and took some articles on Credit, at noon $\mathrm{Nez}$. Corbain came again to receive a Present from $\mathrm{Mr}$ Manuel Lisa and as soon as received, departed for the Village.

friday the 28 , clear and the house fur trade was commenced made $36 \mathrm{Packs}^{115}$ of different Peltries and prepared the Boat which had to go to St I.ouis.

Saturday the 29th, clear, this Morning the Men which came by Land from the Bigbellies arrived with the horses, they had met with no Accident, they informed that the Mandans ${ }^{116}$ had made a Hunt and Killed on One Day

October, 1804. On the return of Lewis and Clark from the Pacific Big White accepted their invitation to visit their "Great Father" at Washington. He was accompanied by his wife and son, and his interpreter, René Jusseaume. In 1807 Gov. Lewis sent him homeward under a convoy commanded by Lieut. Pryor. Upon reaching the Arikara village they were fired upon, and after several casualties Lieut. Pryor concluded to return to St. Louis. Sheheke remained in St. Louis until June, 1809, when he started on a successful journey back to his people. He was about 46 years old at the time of his death.

${ }^{115}$ A pack of furs contained ten buffalo robes, fourteen bear, sixty otter, eighty beaver, eighty raccoon, one hundred and twenty foxes, or six hundred muskrat skins.

"The Mandans called themselves the "People of the Pheasants" or "People of the East." The early French traders referred to them as the "Bearded Whites." In many respects the Mandans greatly excelled other Indians of North America. They have been called Welsh Indians because of the fairness of the skin and hair of many of the tribe. Catlin says of them: "They are distinct from all other red folks I have seen, differing in many respects both in looks and customs from all other tribes which I have seen." This tribe of Indians were first seen by white men (whose visits have been recorded) in the vicinity of Mandan and Bismarck in what is now North Dakota. This was in 1738. The Mandans were almost wiped out by the small-pox epidemic of 1837 , being reduced from 1,600 souls to about 150 . In 1845 they moved near Fort Berthold, North Dakota, and joined the 
450 Buffaloe, employed in - settling Accounts and writing, at 5 P. M. our hunters brought in the Meat of 5 Cows.

Sunday the 30 th clear, at Io A. M. the Boat started for St Louis ${ }^{117}$ with I3 Men, several others went to the Ree Village to purchase Corn and Skins for covering of the Boat, in the evening they returned and had only succeeded to buy two Bushels of Corn and 8 Hides, the Indians not being willing to trade.

Monday the 3 Ist cloudy and hard wind from the S. W. -made up an assortment to go to the Mandan and purchase Horses for the parties going up the River.

Thuesday Sept. I, cloudy and heavy Squalls, four Men went to the Men to buy horses, made a fish trap of willars, and caught $3 \mathbf{I}$ Cat fish, hunters went out this Morning, and returned in the Evening had Killed II Cow.

Sept. 2d Wednesday hard Gales from N. W. La Plume came to Camp, the wind abated about Sun set cloudy and cold.

Thursday Sept. 3. clear and warm, caught 6 fish very large.

Minnetarees and Arikaras in a stockaded village, where they remained until 1888. Then these tribes separated and scattered to the northward and westward, the Mandans crossing to the southwest side of the Missouri and settling above and below the mouth of the Little Missouri. The Mandans were agriculturists and artisans, and more highly civilized than the other Indian tribes of the Northwest. They lived in circular clay-covered log huts, which were in ancient times surrounded with palisades of strong posts. In 1905 their population was about 250.

${ }^{117}$ This boat arrived in St. Louis about September 27, 1812. 
friday Sept. 4 nothing remarkable, cloudy and cold.

Saturday Sept. 5 the same.

Sunday " 6 the same.

Monday " 7 moved in the new house and began to make Equipments ${ }^{118}$ for the Parties going up the Missouri.

Thuesday 8 finished Equipments, Killed $\mathbf{I 4}$ Ducks.

Wednesday 9 our hunter brought Meat of 9 Buffaloe, were informed the Sioux and Rees had fought a Battle 2 Sioux. Killed 3 Rees wounded.

Thursday Io clear and warm, the Grey Eye Chief and 3 Men arrived from a Scout..

friday the IIth early rise, the parties prepared to start. Mr. Sanguinette and 2 Men with 5 horses for the spanish waters ${ }^{119} \mathrm{Mr}$ Lorimier

${ }^{118}$ Equipment to clerks and boatmen consisted of: I three-point blanket, valued at $\$ 4.00 ; 11 / 2$ yards of blue cloth, $\$ 2.66 ; 1$ calico shirt, 72 cents; I cotton handkerchief, 16 cents; I knife, 17 cents; 3 pounds of tobacco, 18 cents.

${ }^{119}$ The Arkansas River. The Arapaho Indians lived in the neighborhood of this river, which has its sources in the Rocky Mountains to the westward of Pike's Peak. "'The Arkansas River bore the unique distinction among western streams of being an international boundary, and prior to the war with Mexico it was the frontier between the United States and that country from the rooth meridian to its source. This fact gave it an artificial importance which it in no way possessed as a natural water-course. The upper course of the Arkansas was a great resort for traders and trappers, and here arose the well-known Bent's Fort, which held commercial sway for many years over the surrounding country." (Chittenden, History of the American Fur Trade.) 


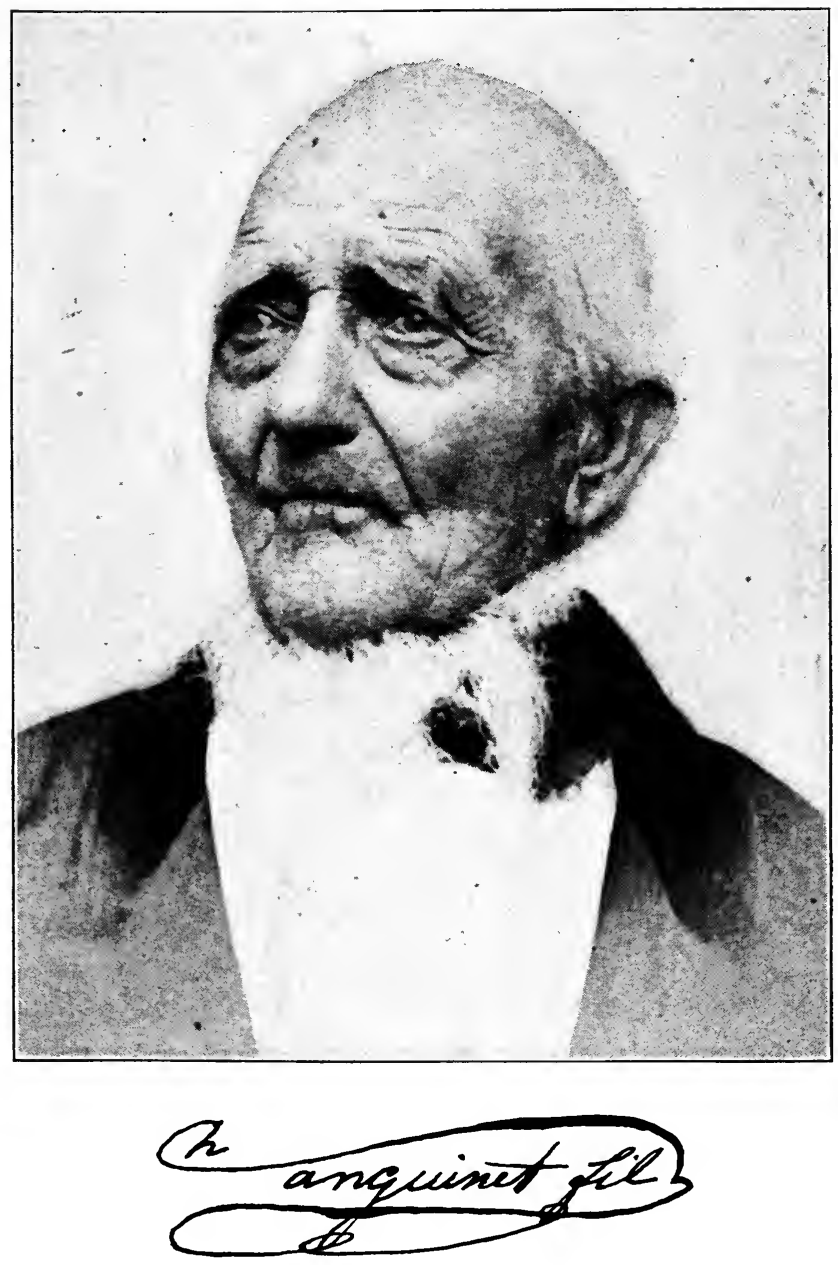



and four for wind River, ${ }^{120} \mathrm{Mr}$ Lewis, two engagees and the trappers for the little Horn ${ }^{121}$ in all $18 \mathrm{Men}$, at noon a Sioux Chief arrived to have a talk with $\mathrm{Mr}$ M. L. and 9 Men with him, cloudy \& rain we traded some dry meat and I Robe.

Saturday the I2, the Sioux started this Morning, as also Mercier, ${ }^{122}$ LaChapel and Carri$\mathrm{ere}^{123}$ for their fall hunt down the Missouri, Killed ${ }_{4}$ Ducks.

Sunday the I3th fine weather, began to hawl stone for Chimneys our hunters went out finished the store caught 15 large fish.

Monday the 14 last Night a Ree Chief Legross ${ }^{124}$ came to fort with his Wife he was lamenting the Death of one of his Children which had died 2 Days ago, Mr Manuel covered the Dead Child, Legross being a good Indian, this morning had 22 fish fine warm weather,

${ }^{120}$ Bighorn River. It is the principal tributary of the Yellowstone; rises in the Shoshone and Wind River Mountains in Wyoming. At its mouth Manuel Lisa established a trading-post in 1808 and named it Fort Raymond The upper course of this river was known for a time as Wind River.

121 Little Bighorn, one of the tributaries of the Yellowstone. This river is famous as the scene of the Custer massacre.

${ }^{122}$ Antoine Mercier was born at Kaskaskia, Illinois, November I5, 1766, the son of Joseph Marie and Catherine (Desgagniers) Mercier. He was in the service of the Missouri Fur Company from 1809.

${ }^{123}$ Eustache Carriere, a native of La Rivière du Chene, the son of Baptiste and Marie (Lajeunesse) Carriere. He married at Florissant, Missouri, January 3, I820, Josette Therese Jusseaume, daughter of René Jusseaume, the Indian interpreter. There was a Carriere with the Hunt party of Astorians, who was lost "never to be heard of later." There was also a Michel Carriere at the American Fur Company's Fort Tecumseh in $1830-1833$ and later at Fort Union.

${ }^{124}$ Le Gross ("Big Man"), a ferocious-looking, gigantic fellow. He was the principal war chief of the Arikaras when Brackenridge visited this tribe in $18 \mathrm{I}$. 
our hunters returned with 6 Cows and the pleasing news of plenty in the prairies.

Thuesday the $\mathbf{I}_{5}$, moved in the Store, took an Inventory caught 8 fish, warm and clear.

Wednesday the 16 fine weather nothing remarkable.

Thursday the 17 the Wind blew heavy from the N. W., abt 6 A. M. the Men who went to gett the Horses, came back and told the sad news that 5 Indians, supposing Grosventers had mounted the horses in their Sight and rode them off. 7 in Number, Charbonneau ${ }^{125}$ who was on horse back came in full speed to the fort and cried out; To Arms Lecomte ${ }^{\mathbf{1 2 6}}$ is Killed, he run off and left the poor fellow, the Indians spoke to Lecomte and they told him to go about his busines he asked them what Nation they were, they answered Crows $^{127}$ if the Indians had an Idea to Kill

${ }^{125}$ For a sketch of Toussaint Charbonneau, see Appendix.

${ }^{126}$ François Lecompte. In the contract of engagement of François Lecompte with the co-partnership of Lisa and Drouillard, dated September 24, 1803, the former is referred to as an "habilant de la Madelainne." Under this engagement he was to serve three years as hunter and trapper and at the end of that period agreed to return to St. Louis, and, if mutually satisfactory, to renew his contract. On June 30, 1807, at the Kansas River, Lecompte agreed to remain in the service of Lisa. He attached his mark to the document, which was witnessed by Robert McClellan. There was a François Lecompte in the service of the Northwest Company previous to 1803 , and it is probable that it was this man.

${ }^{127}$ The Crows, called Absaroke, "crow," or "bird people"; the eariy French traders referred to them as gens des corbeaux. This tribe are of Siouan origin, forming part of the Hidatsa group; separating from the Hidatsa (as Matthews believes, about 1694), they left their villages on the Missouri and migrated to the region of the Rocky Mountains. They were a roving, quarrelsome, and thieving people. Maximilian 
him they might easy have done it, ro armed Men went immediately after them but returned without Success they saw them no more, a cloudy Day and cold.

friday the 18 disagreeable weather, the wife of Elie $^{128}$ a Snake Squaw died, made a Wolf trap and raised the Mens house.

Saturday the I9th Charbonneau and Jessaume ${ }^{129}$ departed for to go to the Bigbellies, to try to get the horses Bijou arrived from his Station with ro Sioux, (Saunie) to make peace with the Rees, as Mr M. L. had proposed,

considered them the proudest of Indians, despising the whites. While they did not wantonly kill the whites, they never missed an opportunity to plunder them.

${ }^{128} \mathrm{Joseph}$ Elie, or Helie, as it was sometimes written, entered the employment of the Missouri Fur Company in 1810 . He was a Canadian, born about 1786, and died in St. Lou1s, January 14, 1816.
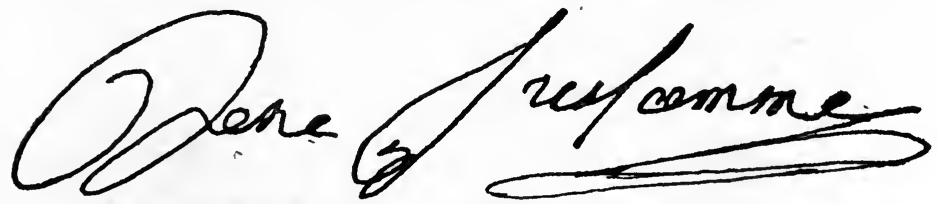

${ }^{129}$ Rene Jusseaume, sometimes called St. Pierre, was a native of Canada, and claimed to have been in the Mandan villages as a free trader as early as 179I. He was in the employ of the Northwest Company on the Red River in 1793, and served as guide and interpreter to David Thompson on his voyage of exploration in 1797. He was interpreter for Lewis and Clark at Fort Mandan, and accompanied the Mandan chief Sheheke and Capt. Meriwether Lewis to see the President in 1806 . On the first attempt to convey the Indian chief back to his home Jusseaume was wounded by the Arikaras. He was brought down to St. Louis and cured, and finally returned to his home with Sheheke, in 1809. In 1811 and later he was in the employ of Manuel Lisa. On August 24, I817, Toussaint Jusseaume, son of René Jusseaume and Catherine des Bois, married Marguerite Bergan at $\mathrm{Ca}$ hokia, and on January 3, 1820, at Florrissant, Missouri, Josette Therese Jusseaume, daughter of René, married Eustache Carriere, also of this expedition. 
at 2 P. M. our hunters brought in 3 Elk fine Evening.

Sunday the 2oth a clear but cold Morning 2 Rees arrived in search of a Women which had run off, after Breakfast Immel and 4 Men went hunting, in the afternoon Goshe and 3 Men arrived he seemed not much pleased with the Sioux, they harangued much this Evening, and to Morrow was fixed to smoke and make Peace.

Monday 2ist fine weather and warm, one of the Warriors of the Sioux after having taken a little mixed whisky, pretended to be drunk, and cut Capers about like a mad Men, which determined the Business with the Rees, it was resolved that the Sioux should depart in the Evening unseen by other Indians which might hurt them, they spent the Day agreable together and at 8 oclock in the Evening they crossed the River, accompanied by a few Presents. Bijou who was to go by water found the Canoes not good and remained.

Thuesday the $22 \mathrm{~d}$ fine warm weather and clear Bijou loaded his Canoe and went down the River with Manegre, ${ }^{130}$ at 10 A. M. Goshé and party also started and Immel came home with I Elk and 2 Deer very fat he found no

${ }^{180} \mathrm{Louis}$ Manegre. There was a family in Cahokia, Illinois, in the latter part of the eighteenth century, of this name, though they used several variations in the spelling, such as Manegle and Manaigle. Joseph Manegre was one of the original claimants of land in Kaskaskia, Illinois. According to the Missouri Fur Company's book, Louis Manegre deserted; the last entry being September 21, I812. 
Buffaloe traded 2 horses, in the Evening a Rees and 2 Woman to trade a horse.

Wednesday the 23 fine and clear weather, set 2 hens with 22 Eggs, traded the horse in the Evening another arrived to trade a horse and also his Wife, a handsome Squaw he found trade for the horse but not for the Wife, a Mandan arrived, no news from above.

Thursday the 24th fine warm weather for the Season traded some Corn the Indians went to the Village, Immel and 3 men went hunting took ro traps and 7 Horses with him, in the Evening Nez Corbain and 50 Men of the Yentonas arrived.

friday $25^{\text {th, }}$ Rain and windy traded some Meat with the Indians, after dinner they brought in their Plunder for trade and we traded several Peltries, a large quantity of dry meat and tallow, held a Council and made a Present of ro lb. Powder I 5 lb. Ball, I Kegg of mixed Whisky.

Saturday the 26 , they were preparing to move, when we found they had stolen a foot Adge and a handsaw, by giving a Hand Kerchief to the Chief he promised to return them we got the Adge but not the Saw, when they were gone we found our table Knives and the Door of a large had also departed at $2 \mathrm{P}$. M. our hunters came in with 4 Buffaloe, they had left Immel with one Men to trap Beaver.

Sunday the 27th nothing remarkable, Rain, 
blew a hard Gale and continued so all Night till

Monday the 28 in the Morning when it cleared up our Hunters went out for Meat, and in the afternoon about 40 Sioux arrived to trade, in the Evening a hard thunder Storm-

Thuesday the 29th had cleared up, began to trade they had not much peltry, at $9 \mathrm{~A}$. M. the Indian crossed again.

Wednesday the 30 th clear'and fresh at 2 P. M. our hunters came in with the Meat of 3 Cows 2 Deer, 2 whole Beaver and Beaver meat, Immel having caught $\mathrm{I}_{4}$ Beaver.

Thursday the Ist of October, at Sunrise we had to cross a band of Sioux, accompanied by $\mathrm{Nez}$ Corbain and another Chief called Boite about 40 in Number they traded and returned at noon satisfied, in the afternoon 7 Men started up the River with the Mackina Boat to hunt Buffaloe, and Immel came home with 15 Beaver I Otter and 2 Muskrats; the wind blew very hard from N W and the Boat returned.

friday the $2 \mathrm{~d}$ the Boat went again early in the Morning the wind arose from the same quarter they stopped at the first point above four Rees came to fort.

Saturday the 3, clear and cold had white frost this Morning Majet and all hands employed to cut Picketts, at Sunset 2 Mandans arrived with the sad news of the Big white and 
Little Crow ${ }^{131}$ being Killed by the Bigbellies and 3 Mandans wounded, the Bigbellies had II Men Killed and a Number wounded, at night Charbonneau \& Jessaume returned and brought with them 3 of the horses which had been stolen by the Mandans and not Bigbellies as supposed a lesson to take care of our property, no matter friend or Ennemy.

Sunday the 4 th the Mandans went to the Rees accompanied by 3 Rees fine weather.

Monday the 5 th Immel went to the Village with $\mathrm{Mr}$ Manuel returned in the Evening they were informed the Sioux had stolen 3 horses from us in the night of the $3 \mathrm{~d}$ instant and by examination we found one of Company one of Goshé and one of Charbonneau gone-

Thuesday the 6th last night the Dogs made alarm we went patroalling, heard some whistling of Men, but found in the Morning our horses safe, raised the right wing of the out houses and Kept our horses housed.

${ }^{131}$ Kago-ha-mi, Little Raven, better known as Little Crow, a Mandan chief. On October 29, I804, Captains Lewis and Clark held council with the Mandans and distinguished some of the leading men of that nation by making them chiefs. In this manner Little Crow was made second chief of the lower village and was presented with a medal bearing the impressions of domestic animals. He was very friendly to the men of that expedition. When Capt. Clark requested the Mandans to choose a confidential chief to return with the expedition and visit President Jefferson, Little Crow showed a willingness to accept the honor. Later he declined to accompany them and refused the flag which Capt. Clark wished to present to him. His refusal was occasioned by jealousy between him and the principal chief, Sheheke, Big White. After some persuasion the chiefs became reconciled!and agreed that Big White should go in place of Little Crow. 
Wednesday the 7 th fine warm weather all hands to cut Pickets a beautiful Day for the Season nothing remarkable-

Thursday the 8 th this Morning 2 horses were stolen in sight of the house, distance 150 steps the Men who had to take care of the horses went to his Breakfast and returning the horses were gone.

friday the 9th clear and fine weather, in the afternoon 4 Rees arrived to give us Notice that their Corn was gathered and ready for trade. Charbonneau \& Jessaume Keep us in Constant uproar with their Histories and wish to make fear among the Engagees, these two Rascals ought to be hung for their perfidy, they do more harm than good to the American Government, stir up the Indians and pretend to be friends to the white People at the same time but we find them to be our Ennemies.

Saturday the 10 fine weather, the Rees went home again Garrows Wife a Ree Squaw Sister to the Chief Goshé, came to fort last night, this Morning she was going to shot her husband, she came here with that Intention, some Rees arrived which were enraged against Charbonneau \& Jessaume, having heard of their arrival from the Bigbellies they said that C. \& J. were Lyars and not to be considered as good french men, and if Mr Manuel Lisa would sent them to the Grosventer with a pipe they would not consent such 
Credit have these Men amongst the Indiansthey find their Character gone and try every Scheme, to Keep themselves alive like a Men a Drowning, I shall leave them for a while, and go on with my Observations.

Sunday the IIth Immel and others went with the Boat to the Ree Village to trade Corn, late last Evening the Boat and hunters arrived with a fine Chanoe of Meat they had Killed 19 Cows and 4 Elk, but lost the meat of 7 Cows by the Wolves, there are incredible quantities of Wolves in this parts, they go in gangs of 3 to 400 and at Nights the Prairies echo with their howling but nothing of this Kind can prevent the Savage of his favorite Walk, to Kill and steal at night, this Day finished our new Provision Store, and go on with the other houses, the Horses are Kept under Lock and we fear no Lurking Savage.

Monday the 12 we had frost last night, the Vessels full of ice clear and cold Morning, but calm and warm in the afternoon cloudy evening.

Thuesday the 13, white frost, cloudy, this Morning our Cart man was attacked by 5 Wolves, but cleared himself Immel returned, the Rees will not trade Corn with us.

Wednesday the I4th, fine clear weather, 4 Men went out to hunt, some Rees arrived to trade a little Corn and a Girl the first was traded, but the last not, she wanted to be the Wife 
of frenchman, and not his concubine,-Chastity.- got this Day 2r Chickens.

Thursday the 15, This Morning Immel, Papin and Charbonneau started for the Grosventer, $\mathrm{Mr} \mathrm{M}$. Lisa having engaged Charbonneau for some good reasons at $8 \mathrm{~A}$. M. a Band of Chajennes about 12 Lodges arrived their Chief named Lessaroco, they had plenty Women \& Children and a great Number of Dogs, traded some Beaver, and about 50 Bushels of Corn.

friday the 16 th, clear and warm, the Chajennes went off they behaved very well. traded tranquil and in the afternoon 2 young Men brought our Hogs back which had followed them.

Saturday the 17, cloudy, Majet and hands crossed the River for Picketts, in the afternoon some Rees arrived, traded 6 Beaver and some Corn.

Sunday the 18 , cloudy \& cold, Boat went for Picketts again.

Monday the 19 the same as yesterday.

Thuesday the 20, snowstorm, at 3 P. M. Goshe arrived with 4 Chajennes of a large band, they came to inform themselves how we traded, and observe we had not Goods enough for their Peltries, we shall see when they come?

Wednesday the 2ist cold and cloudy, this Mornla ing the Chajennes went off and Goshe re- 
mained, at noon 2 of our hunters came in with Meat of 2 Cows.

Thursday the $22 \mathrm{~d}$ clear and cold, the 2 hunters went out again, commenced the Stockade of the fort.

friday the 23 clear and cold had 3 Kittens this Day.

Saturday the 24 clear and cold after Dinner our Heroes arrived from the Bigbellies, they brought a Pipe and 3 Bladder for the Rees, their Mission had been successful and all Differences existing between them and the whites settled at the same time our hunters arrived with Meat of 2 Cows. they had Killed 7 and caught 20 Beaver I Otter 2 Muskrats and Killed 2 Wolves.

Sunday the 25, clear and cold nothing to remark. Monday the 26 , the same. Mr Manuel L. went accompanied by the 2 Interpreters, Papin and 3 Men to the Ree Village with the Pipe of the Bigbellies.

Thuesday the 27 clear and cold hunters went with 7 Horses but returned in the Evening, having seen some Lurking Savages. Mr. M. L. returned from the Village successful

Wednesday the 28 th clear and moderate warm, our hunter took an early start across the River with 6 Horses. at evening 4 Rees and I Mandan came to the fort from the Mandans, they informed the brother of Legrand ${ }^{132}$

"2"Le Grand, Ohheenarw, or "Big Man," "a Cheyenne, was taken prisoner by the Mandans, who adopted him; he now enjoys the first consideration among the tribe". (Lewis and Clark, Coues ed., p. 182.) 


\section{had died of his wounds, received in the Battle with the Bigbellies.}

\section{Thursday the 29th clear and warm, finishing writing and at II A: M. Lajois ${ }^{133}$ and Gogal ${ }^{134}$ two Engagees set sail in a Canoe for St.}

${ }^{133}$ Louis Lajoie, son of Joseph and Francoise (Trudal) Lajoie of Masquilonge, Quebec, where he was born about 1778. He married, first, Celeste Tabeau, daughter of Jacques and Susanne (Jarret) Tabeau, February 3, 1801, at Florissant, Missouri. Three children were born of this marriage: Margaret, October 6, 1802; Charles, September 25, 1804; and Joseph, August 9, 1807. After the death of his wife, he married Susanne Charette (Jarret'), daughter of Henry Charette, or Jarret, at Florissant, September 7, 1829. The second wife appears to have been a relative of his first wife, having the same name as the latter's mother. Ten children were born of this second marriage; five of them dying in infancy. In 1833 he testified in a land suit that he was living in Florissant sometime before 1800 and was about 22 years old at the time; that he had previously come to St. Louis for the purpose of obtaining a Spanish Government concession of land, which he received from Gov. Delassus, February 19, 1800. He also testified that he was oftener drunk than sober; that he recollected having sold his interest in the grant, when in a frolic, for a pint of whiskey. Being asked what was his occupation at that time, he answered, "Drinking drams." He testified that he supported his family by working by the day when sober; that since a few years he had left off drinking. He remained in St. Louis County until about 1840 , after which he joined his old friends, the Robidoux, at Black Snake Hills (St. Joseph, Mo.). Four of his children's marriages are recorded in the cliurch register of the Cathedral at St. Joseph, viz.: Henry Lajoie to Sophie Papin, January 7, 1847; Margaret Lajoie to Allen Wallis, January 18, 1848; Louis Lajoie to Maryanne Wallis, January IO, I848; and Octavia Lajoie to John Picard, May I, 1855 .

${ }^{134} \mathrm{Joseph}$ Joyal of Montreal, Canada, son of Antoine and Agathe (Ribeau) Joyal. He was married at St. Louis, August 3,1818 , to Therese Labadie, daughter of Joseph and Genevieve (Labuiche) Labadie, dit $\mathrm{St}$. Pierre. Ten children, two of whom died in infancy, were born of this marriage: Oliver, born February 2, 1821; François, born December 12, 1826, was drowned in 1853; Louise Amanda, March 31, 1829, who married William J. Johnson; Antoine, April 26, 1831; Agathe, April 22, 1833; Joseph, May 17, 1835; Elizabeth, April 16, 1838, who married Alphonzo Boucherelle; and Edward, who was killed in the Civil War. In 1832 Joseph Joyal made his will, mentioning his wife, Aglae, and his children, Oliver, Marie, Francois, Amanda, and Antoine. Three children were born after he made his will. Joseph Joyal died at St. Louis, December 5, I84I.

There was a Joseph Joyal ooyageur in the Northwest Company on upper Red River in 1804 . 
Louis, with a few Peltries \&a cloudy evening at II P. M. Goshé and Legross with 4 Warriors came to fort with a Pipe for the Bigbellies

Friday the 30 th Charbonneau and the 4 Warriors marched off to the Bigbellies, our hunters returned with Meat of 2 Cows, they had met plenty but very wild and could not Kill.

Saturday the 3 Ist Snow this Morning, cleared up at noon and had fine weather, nothing to remark.

Sunday November I, frost last Night, cold and clear several Rees came to the fort, Woahl ${ }^{135}$ and Chain ${ }^{136}$ returned from trapping, they brought 53 Beaver I Otter 5 Muskrats 2 Wolves 2 Mink 20 foxes 7 Elk Skins.

\section{Monday the 2d, cloudy and hard Gales from}

West a hunting party was prepared to go up the River in the Boat, but blewing to hard were prevented.

${ }^{136}$ François Oulle. This name is on the Company's books of 18121813 as Oul, Oull, and Ouelle. There was recorded in the church register of Cahokia, April 2, 1799, the marriage of Antoine Oule, son of François Oule and Marie J. Laroche. François Oulle appears to have been an independent trader, and is likely the man referred to in the church register.

${ }^{136}$ Pierre Chaine, variously spelled Chene, Chaine, and Chesne. The Chesne family was one of the most important in Detroit in early days. At least two members of this family served with the British forces during the Revolution. One, Isadore Chaine, was interpreter for the British forces at Post Vincennes in I779. Tanguay gives the births and marriages of several Pierre Chaines, but there is no way of identifying these with the person referred to in this journal. A Pierre Chaine married in St. Louis, in 1853, Catherine Perrin. There was a Pierre Chene at Fort Benton in 1864, according to Larpenteur's journal. The account-book of the Missouri Fur Company covering this expedition shows that Peter Chaine was sent among the Mandans on April 17, 1813. 
Thuesday the $3 \mathrm{~d}$ clear and cold the Boat started with 12 Men at $8 \mathrm{~A}$. M. in the afternoon a Partizan ${ }^{137}$ (Camerad of Mr. M. L.) of the Sioux (Saunies) arrived with I9 Men, they wanted absolutely Mr Manuel Lisa to go with them to their hunting ground and trade very hard Gales and cloudy evening late in the Evening Grey head a Mandan Chief came to the fort with his family.

Wednesday the $4^{\text {th }}$ cloudy and Snow Squalls Mr. M. L. wished to follow the Boat by Land was prevented by the Sioux, they were not willing to go home in the Evening several Rees and 3 Mandans arrived.

Thursday the 5 th Snow storms all last night until 8 this Morning when it cleared up, cold weather.

Friday the 6th clear and cold, much Ice in the River the Sioux went off this Morning across the River fearing to go on this side of the Rees, Grey head, Rees and Mandan started also, and Garrow the Interpreter left the fort with his Wife, on Account of 'a quarrel between his Wife and Baptist Provost. ${ }^{138}$

187"Partizan" meant a warrior, usually, or the leader of a war party. There was a Teton Sioux Indian called Partizan in the deputation which came with Manuel Lisa to make a treaty of peace at Portage des Sioux, Missouri, in 1815. This man had attempted to stop Lewis and Clark on their journey to the Pacific Ocean. Le Grand Partizan, a Dakota warrior, was at the council with Gen. Pike on the St. Peter's in 1805. "He was not a signer, probably not more than a principal soldier, certainly not a chief." (Minnesota Historical Society Collection, I:381.)

${ }^{128}$ Jean Baptiste Prevot. There were many variations in the spelling of this name, the most common of which were Prevot, Prevost, and Provost. This man, the son of Jean B. and Marie, "a sauvagesse of 
Saturday the 7 th Baptist Provost was turned out the fort Immel went to hunt with 3 Men and 6 Horses, at i I A. M. Langue de Buche a Ree Chief and his party arrived engaged Pierre Chaine to hunt for the fort in the place of Baptist Provost, the River full of Ice, clear and cold.

Sunday the 8th Langue de Buche ${ }^{139}$ and party went off to make his Camp for winter about 6 miles above the fort, ${ }^{140}$ at 2 P. M. Immel returned with Meat of 4 Buffaloe several Rees at the fort, clear and cold.

Monday the 9th, cloudy and moderate, snow fell in the afternoon, nothing remarkable.

Nation Otto," was born in St. Louis, September 10, 1773. He married in St. Charles, Missouri, October 1, 1795, Felicité Cote, daughter of Alexis and Elizabeth (Dodier) Cote. The record of this marriage is the second in St. Charles, while his father's second marriage was the first recorded there. Two children were born of this marriage and were baptized in the St. Charles Catholic Church: Jean B. Prevot, born February 20, 1797, and Pierre, born December 4, 1798. Prevot seemed to have had difficulty keeping out of jail on account of his inability to meet his debts. On June 21, 1816, "Jean Baptiste Janot Provot (by his mark), in prison bounds in St. Charles," gave notice that he would take the benefit of the bankruptcy act. Two years later, at the instance of Auguste Chouteau, administrator of the estate of Paul Lacroix, Baptiste Janot Provost was again confined in jail.

Audubon, in his Missouri River journals, makes almost daily references to "old Provot," hunter, and in his entry of October 18, 1843, is the following: "Landed at St. Charles to purchase bread, etc. Provost became extremely drunk and went off by land to St. Louis." I am inclined to think these two men are identical. There was a Jean B. Provost, a native of Canada, living in Carondelet, where he died in 1834, aged 50 years. In the St. Louis Directory of 1840-4I, John Prevost, "an old sailor," is given as living on Fifth Street between Wash and St. Charles.

${ }^{130}$ Langue de Biche, or "Elk's Tongue," was second chief of the Arikaras. After the death of Grey Eyes, in the attack on the American trcops and traders, Elk's Tongue took command of the war party. One chronicler calls him a "tonguey old politician." He was living with his people on the Upper Platte in 1824.

${ }^{140}$ About Four-Mile Creek in Morton County, North Dakota. 
Thuesday the Ioth, snowed all night, cleared up about 8 oclock in the Morning, moderate, Immel went out again to hunt with the same Men, Buffaloe in Sight, some Rees arrived.

Wednesday the II clear and moderate, nothing remarkable.

Thursday the I2, cloudy 3 Rees which had camped with us last night went away displeased getting not enough to eat and set the Prairie around us a fire, Immel returned with 5 Cows.

Friday the I3th Papin and I Man went to the Village, to try to get the Rees to make a great Hunt for us. Mr. M. L. promised 20 Loads Powder \& Ball for each Cow the Buffaloe being very near and plenty. Charbonneau returned in the afternoon from the Bigbellies and four of their head Men with him, the Chief Cheveux Loup and 3 others, some Rees and a Chajenne Chief (Papilliar) arrived in the Evening with the news the Chajenne were close by and came to trade, traded 2 Beaver.

Saturday the I4th, cloudy and cold, Papin returned with tidings that the Rees were preparing to make war on us. Baptist Provost and Garrow had told them many Lies and roused the Chiefs and Nation against us, which proved to be fact, we found this Day 6 of our Horses stolen, 2 Rees arrived to sound us if we were inclined for War, the Chajenne Chief went to the Village. 
Sunday the $1^{\text {th }}$ This Morning, Immel, $\mathrm{Pa}$ pin and Charbonneau left this for the Village, with the Bigbellies and 3 Rees, to see into the Misconduct of those fellows and try to settle amicable, the Rees which remained at fort, seemed tranquil and content, we stopt all Work cleared the fort, and prepared for Defence in Case of Necessity, sent Pierre Chaine \& Pointsable ${ }^{141}$ to the Camp [of] Langue de Buche, to hear some news of the stolen horses.

Monday the 16, last Night Pierre Chaine returned and informed that the horses had been stolen by the Rees, by the Order of Garrow and were at the hunting Camp of Grey Eye, Langue de Buche arrived this Morning with 8 Men going to the Village he promised to deliver the horses in three Days, and requested $\mathrm{Mr}$ M. L. to be tranquil, Matters would be settled,- - traded some Meat and I white Bear Skin of them-at 4 P M. our Deputies returned with the Bigbellies accompanied by Goshé and Plume d'aigle, Garrow and many other Rees, to arrange the Difficulties which had arisen, all was thrown on the Shoulders of Baptist Provost.

Thuesday the $\mathrm{r} 7$ th fine weather, clear and warm, held Council and finished with Peace, two of our horses were brought in this Morning, finished the Enclosure of the fort.

Wednesday the 18 , fine weather, and tranquility restored the Bigbellies requested a trader and being promised one, left this for their ${ }^{141}$ For a sketch of Jean Baptiste Point du Sable, see Appendix. 
Village, as also the Rees very well satisfied, another horse was brought in, Pierre Chaine and 2 Men went over the River hunting, Buffaloe and Elk in Sight.

Thursday the 19th clear and warm little Ice in the River at four oclock in the after noon hung the great Door of the Entrance of the fort, which ceremony was saluted by 7 Guns . and 3 rounds of Musquetry, made the Touraround the Fort and Baptized the same $M A N U E L^{142}$ in the Evening a good Supper and a cheerful glass of Whisky was given to the Men, and a Dance at which all the Ladies then in fort attended, concluded the Day, Garrow brought his family to fort again and traded of the Rees a horse which had been stolen of the Company last year by the Sioux.

Friday the 2oth, clear and cold, had a Deer Killed nothing remarkable.

Saturday the 2r, cloudy Morning, cleared up at noon Immel \& Papin went to the hunting Camp of Grey Eye, to get if possible the remainder of the stolen Horses. Legross came to the Fort with Baptist Provost to explain his Conduct and be taken in favor again. Provost was not permitted to enter, they blamed Garrow for all the Mischief which had been done, but went off without Success, Immel returned with only our Running

${ }^{142}$ For a minute and intetesting description of trading-posts and forts, see Chittenden's History of the American Fur Trade, Vol. 1, page 42. 


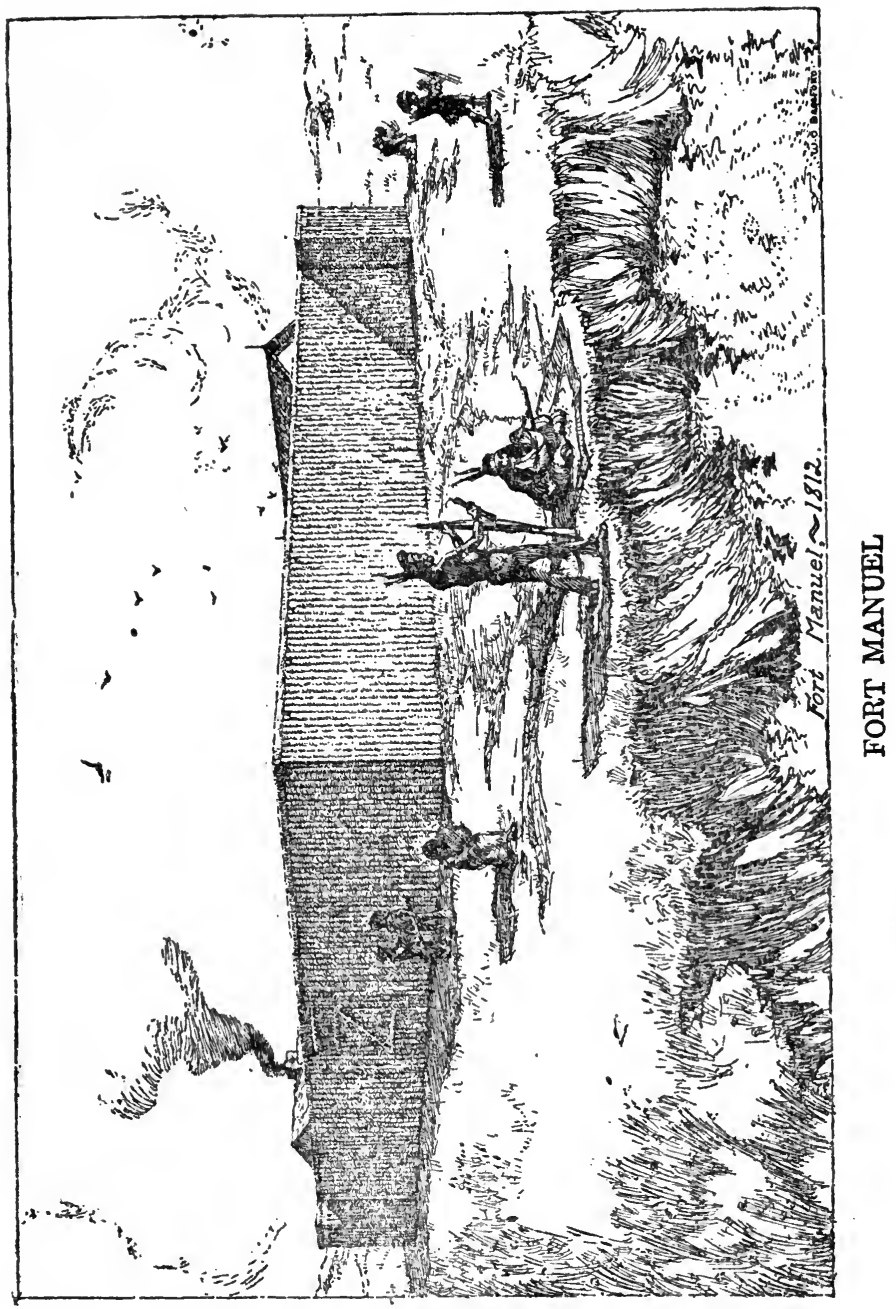


Mare the other 2 horses they the Indians had sent to the Village loaden with Meat, the horses returned were all ruined and their Backs very soar, the Chajenne Chief returned from the Village.

Sunday the 22d Morning clear and moderate, the Chajenne Chief went to his Village, in the Evening our hunters came to fort, they had Killed only I Cow and I Deer and found very few Buffaloe, evening cold.

Monday the 23d Snow in the Morning, having been informed, the Saunie, Sioux, had arrived with about 150 Lodges at the Rees, Charbonneau and Garrow set off for the Ree Village, to Know if they the Sioux had any thing to trade. Mr. M. L. Immel and Chain went to a band of Chajennes which were camped about 5 Miles above the fort, ${ }^{143}$ with the same intention but returned shortly afterwards, having met with one Chief and 2 Partizans coming to pay us a Visit, and inform themselves how we traded, cleared up at noon pretty cold, wind North, plenty Ice in the River, this Day crossed our horses to the other Side.

Thuesday the 24th clear and very cold, Garrow \& C. returned from the Sioux, with News that they had nothing to trade but Meat; the Chajennes went to their Camp, and promised to come to trade with what they had, five Rees arrived at fort.

\footnotetext{
${ }^{143}$ About Fire Heart Butte in Morton County, North Dakota; on Missouri River Commission map.
} 
Wednesday the $25^{\text {th }}$ hard frost last night, and cloudy. hawled the Boats out of the Ice, this Evening a Number of Rees came to the fort to camp.

Thursday the 26th, moderate and cloudy, the Rees went off, and our hunters started with 8 horses, at noon the Chajennes arrived with 26 Lodges and made their camp at the Point above us, 5 of their Chiefs came to the fort. they have a vast quantity of horses and Dogs. Rain.

Friday the 27th Snow in the Morning and cold, plenty Chajenne in the fort, they invited $\mathrm{Mr}$ Manuel to a feast, to which he and Immel went, Grey Eye brought the last stolen horses, traded some Beaver.

Saturday the 28th last Night the River closed, moderate and clear, plenty Visitors, but no trading.

Sunday the 29th cloudy and cold, traded some Beaver Robes \&a.

Monday the 30 th, cloudy and cold, traded again one of our hunters came in with the Meat of 2 Cows were informed by the Rees that Mercier, Lachapel and Carriere were Killed by the Sioux, these 3 Men were trapping about the Big bend.

Thuesday the Ist of December, cloudy and very cold. traded little, the Chajennes informed us that 2 very large Bands of their Nation were camped above them, which would also come to trade. 
Wednesday the $2 \mathrm{~d}$ several Mandans arrived and demanded a trader, Pierre Chaine brought in I Cow.

Thursday the $3 \mathrm{~d}$, cloudy and very cold, Immel and 3 Men went out hunting.

Friday the 4 th, cloudy and cold, Pierre Chaine and I Men went out spying for Buffaloe, the Chajenne Chief (Medicine Men) brought us I Cow, round, the 5 . Chiefs received a small present and were well satisfied with our treatment, I wished to Know their Names but could only learn, besides the one named above one more, which was named the poor Little Wolf.

Saturday the $5^{\text {th }}$ Pierre Chaine sent in this Morning for horses, he had Killed 4 Cows, fine clear and cold weather the Meat of Chaine and Immel with Meat of 2 Cows arrived in the Evening.

Sunday the 6th, clear and cold. Mr Manuel L. went on a Hunting Party with the Chajennes, there being 1000 of Buffaloe opposite, returned at noon and had killed I 2 Woahl also brought in one Cow, Baptist Provost came to the fort again, Mr Manuel having pardoned him by information received, that it was not alltogether his fault, Goshé and many Rees arrived.

Monday the 7th cold and cloudy, nothing remarkable.

Thuesday the 8 . the same as yesterday. 
Wednesday the 9th clear and fine moderate weather Baptist and 5 Men went out hunting, Goshé to his Village.

'Thursday the Ioth clear as yesterday, nothing remarkable.

friday the IIth the same, the Chajennes left us to camp and hunt at the fourth Point above us, we had traded with them 75 Beaver, 2 Muskrats, 4 dressd Buff. Skins, 7 white Bear, Io Robes, 5 Otter, 3 foxes I wild Cat, 450 pair of Moccassins a quantity of tongues and some Meat.

Saturday the 12, cloudy, opposite the fort the Prairie is covered with Buffaloe, Bapt and Men arrived this Morning had Killed 4 Cows and 2 Bulls, in the afternoon, Baptist Antoine alias Machecou, ${ }^{144}$ arrived express from $\mathrm{Mr}$ Lewis and brought the displeasing news, that the hunters which were equipped by the Company and which had been on the Spanish Waters trapping, had been robbed by the Crows, one of them Danis ${ }^{145}$ was Killed by

${ }^{14}$ Baptiste Machecou, dit Antonio. It is difficult to determine whether this is an Indian, a French, or a Spanish name, or a corruption of all three. The word Machecou is given in Hodge's Handbook of American Indians as a tribal name for Creek Indians. Baptiste Machecou might have been the brother, or a kinsman, of Pedro Antonio, a Spaniard, who, while in the employ of Lisa, was killed by the Sioux in the spring of 1817. This Pedro Antonio lived at Harrison on the Merimec in 1809 . He married the daughter of James Head. The accountbook of the Missouri Company shows that Baptiste was with the Company from August, 1812, to April, 1813, and that he received extra compensation for going to the Crow villages with Louis Lorimier.

145 Jean Baptiste Danis. Probably of the Charles Danis family, who received the first grant of land in Kaskaskia in $\mathbf{1 7 2 2}$. Jean Baptiste Danis was in the employ of the Missouri Fur Company from its organization. In 1803 he was living in New Madrid County near the present town of Portageville. 
some Indian supposed Grosventres, the Day Messrs. Lewis \& Lorimier arrived at the little Horn River, Machecou departed from the Little Horn River in Company with Duroche, ${ }^{146}$ but unfortunately separated 2 days ago in a Snow Storm, Duroche has the Letters of Messrs Lewis and Lorimier.

S unday the I $3^{\text {th }}$ cloudy, some Rees (of whom we have always plenty in the fort) went over the River hunting in the afternoon. Cadet Chevalier ${ }^{147}$ arrived express from $\mathrm{Mr}$ Charles Sanguinette with a Letter dated the $3 \mathrm{~d}$ instant in the Prairie on his Return from the Arepaos, ${ }^{148}$ in which he confirmed the sad News of the hunters, he found none and was informed by the Arepaos, that 3 of them were

${ }^{146}$ For a sketch of Auguste Durocher, see Appendix.

${ }^{147}$ Cadet Chevalier was a free mulatto, and was in the employ of Joseph Hortiz as a trapper and trader on the Great Osage River from 1802 to 1804. There was a Louis Chevalier with the Northwest Company at Lake Nepegon, and it might well have been the same man. In 1805 Cadet was in the service of Lisa $\mathcal{V}$ There is no record of administration on his estate in St. Louis.

${ }^{148}$ The Arapahoes were closely associated with the Cheyennes for more than a century. They called themselves Inunaina, about equivalent to "our people." The Sioux and Cheyennes called them "Bluesky Men" or "Cloud Men," the reason for which is unknown. They were once a sedentary, agricultural people. They were always at war with the Shoshoni, Utes, and Pawnees until they were confined upon reservations. This tribe were generally peaceful toward the whites. In 1892 their reservation in Oklahoma was thrown open to the white settlers, and the Indians received allotments in severalty with the rights of American citizenship. They are much given to ceremonial observations. The annual sun dance is their greatest tribal ceremony, and they were active propagators of the ghost dance religion a few years ago. (Hodge, Handbook of American Indians.) In 1828 they numbered ten thousand souls and occupied territory extending from the head waters of the Kansas River to the Rio del Norte. These Indians were generally well formed, slender and tall, with good countenances. 


\section{Killed by the Blackfeet, ${ }^{149}$ supposed Champ- lain ${ }^{150}$ and 2 others, Lafargue ${ }^{151}$ and 5 others had run off to the - Spaniards, 8 of them}

${ }^{140}$ The Blackfeet were of Algonquian stock. Gen. Chittenden refers to them as "the terrible Blackfeet, the scourge of the Upper Missouri country." The heart of the Blackfoot country was in the valley of the Missouri near the mouth of Maria's River. Under the general head of Blackfeet were included four distinct bands: the Blackfeet proper, the Piegans, the Bloods, and the Grosventres of the Prairie, or Fall Indians. The Piegans were peaceably disposed to the whites as a general thing, and the first successful trading-post established in the Blackfoot territory was built at the mouth of Maria's River, the usual habitat of this band. The Grosventres of the Prairie, or Fall Indians, as they were generally called, were the most relentlessly hostile tribe ever encountered by the whites in any part of the West, if not in any part of America. The trapper always understood that to meet with one of these Indians meant an instant and deadly fight. The Blackfeet Indians were of great importance to the fur trade because their country was the richest beaver district of the West. These Indians were well formed physicaliy, fond of athletic sports, excellent horsemen, and great hunters.

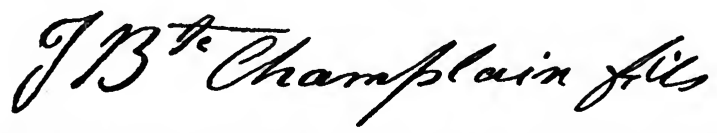

${ }^{150}$ Jean Baptiste Champlain, fils, was a son of Jean Baptiste Champlain, who lived in St. Charles County, Missouri, in 1799. Champlain, fils, owned land in St. Louis and northwestern Missouri, and appears in the records of St. Louis as early as 1800 . He was a man of education and probably a European Frenchman. He went up the river with Lisa in 1807 , returning in August, 1808, and would appear to have gone back up again soon afterwards. On July 6, 1808, he signed, as witness to a note, executed by two of Lewis and Clark's men, John Potts and P. Wyzer (Wiser). On August 13, I8II, he gave to Manuel Lisa a note in the sum of $\$ 321.00$, which is listed in Lisa's estate as "note for collection." On December 7, 1814, Jean Baptiste Champlain, Sr., was appointed at St. Louis administartor of the estate of Jean Baptiste Champlain, Jr., and gave bond in the sum of $\$ 2,000$. Three days afterwards the father made a will in which he says that he is a resident of St. Louis and that he is about to make a voyage on the Arkansas River. He bequeathed half of his property to Pierre Chouteau and named his son-in-law, Alexis Berthelot, as his universal heir. It is possible that Champlain, Sr., doubting the account of the death of his son, went in search of him among the Arapaho Indians. The record showing that he returned is found in the shape of a note executed at St. Charles, Missouri, April 5, 1815, in favor of August Chou- 
had gone to the Crows which now are with $\mathrm{Mr}$ Lewis, and 3 or 4 others they knew nothing off at all, they the hunters had much Beaver some cached and the Remainder plundered with all other things. Mr. Sanguinette requested 2 Men to meet him to transport a parcel of horses, which he had traded with the Arepaos, - the Rees brought in 2 Cows they had Killed 3 had to leave the Meat having no horses, more Rees arrived from the Village.

Monday the 14th Baptist and some Men went out to hunt, plenty Buffaloe about, prepared an Equipment for Immel, who was to go to the Mandan for to trade at 2 P. M. Machecou, Cadet and Colla Glineau ${ }^{152}$ went to Meet Mr. Sanguinette.

teau. Soon after this time the father also died, as his will was probated in St. Louis, but there is no date to show when this was done, nor do the court minutes show any entry in this case. On May 3I, 1816, Peter Provenchere applied for letters of administration on the estate of Jean Baptiste Champlain, Jr. In his application he states that, as far as he knew, Jean Baptiste Champlain, Jr., died without leaving a will, and there were no heirs or legal representatives living.

${ }^{151}$ Jean Lafarque probably lived at St. Charles, Missouri, as there is recorded in the church records there a baptism of Jean Baptiste Lafarque, son of Jean Baptiste Lafarque, May 31, 1818, at which time the son was seventeen years of age. Jean Lafarque was with Manuel Lisa on his first expedition up the Missouri, which left St. Louis in April, 1807. In May, 1800, there was a Lafarque with "Senecal [and party] who were taking lead to Mr. Pere when they were intercepted and seized by Mr. Dubuque by order of Mr. Zenon [Trudeauj." (Pierre Chouteau Maffitt Collection of Manuscripts.) La farque was one of the leaders of a party sent by Lisa to trade on the "Spanish Waters." He escaped from the Arapahoes, but was seized and imprisoned by the Spaniards. He was afterwards released and returned to St. Louis with the Chouteau-De Mun party, September 7, 1817.

${ }^{162}$ Nicolas Glineau claimed citizenship of the United States at the time of his engagement with the American Fur Company in 1831 . 
Thuesday the 15 th fine clear weather, Buffaloe constant in the Prairie, Immel and 3 Men went with 2 Sleighs on the River to the Mandans, had Information that about 80 Lodges of Sioux had arrived with the Rees and still more expected. Garrow went to the Village to invite them again to a general hunting Party all Rees started only One Men remaining, no News of Duroche.

Wednesday the I6th at I in the Morning Garrow returned with the News that the Rees were willing to come if their critical situation with the Sioux would allow it they had quarrelled together and expected to fight a Battle to Day, the Sioux wanted to force and go past the Rees, and camp higher and nearer to us, which the Rees opposed on Account of the Buffaloes, the Rees came and told us a dreadful History which they had been informed by the Sioux, as they sayeth, that the Sioux had Killed Bijou, and plundered the trading house and were singing the Chevelier ${ }^{153}$ for the french, and that they would come

He was probably the same Nicolas Glineau who was a voyageur at River du Sauteux, in the employ of the Northwest Company in 1804 . He was also with the Lisa expedition of 1809 and remained with Henry's party on the waters of the Columbia during the winter of 1810-1811. He appears to have been a free trader, as he received merchandise in I81 I valued at \$2,168, and had in his employ René Jusseaume and Joseph Joyal. While with the Luttig party, he received extra pay in January, 1813, for going to the Mandans, and searching for horses; also in February of that year, for making another trip to the Mandans. For a time he was stationed at the Mandan Posts. In 1831 he was engaged by the American Fur Company as a boatman and to assist in the trade with the Indians of the Upper Missouri. He renewed his engagement the following year. I find no record of his death.

${ }^{163}$ Les Chevelures, "The Scalps," so called by the Canadians. The scalp dance is the most hideous of all Indian customs. When war 
to our fort and do the same, if we would not come to their own terms trading, and in Regard of this Histories Mr Manuel resolved immediately to write a Letter to Bijou and sent it express by a Sioux promising a horse if an answer should be brought to the Letter, at I I A. M. Papin went off with the Letter. Baptist sent in Meat of 8 Cows, and the Men returned to the hunting Camp, at Sunset $\mathrm{Du}$ roche made his Appearance with the Letters of Lewis \& Lorimier which gave some Satisfaction from their quarters they had by hunting and trading 12 Packs of Beaver in Store, and had purchased ten horses for their Use. At II oclock P. M. Papin returned, the Sioux had taken the Letter and promised to deliver an Answer, which revived our hopes that the News of Bijou's Death was not true.

Thursday the I7th fine moderate weather, in the Evening a party of Rees arrived and camped in the fort.

friday the 18 th fine moderate weather, and indeed considering the Season so far advanced is like Spring; we have had but very little snow and of late fine moderate weather so that any Work out of doors may be done, at I oclock P. M. we received 2 horse Loads of

parties returned to their villages after a victory, they placed their trophies on the end of lances and for hours would sing and dance, not infrequently reacting in pantomime all the events leading up to the scalping. Both the men and women participated in this ceremony, with blackened or vermilion-painted faces, looking like fiends of darkness let loose, as Boller expresses it. The scalps are often preserved for a long time stretched upon small hoops, and the hairs afterwards used as ornament to the dress of the men. 
Meat say 2 Cows, at 6 P. M. Goshé, Legross and several Rees came to fort, to make a hunting party $\mathrm{Mr}$ Manuel Lisa having promised a horse to each Chief 4 in Number, when our horses would arrive.

Saturday the I9th fine clear weather, and hard wind all Day, no hunt, a party of Chajenne arrived from the upper Band with one Chief going to the Rees.

Sunday the 2oth, clear and moderate, our hunter say Rees went out and Killed 20 Cows head and foot was received this Evening, purchased a fine Dog of the Chajennes, this Evening the Wife of Charbonneau a Snake ${ }^{154}$ Squaw, ${ }^{155}$ died of a putrid fever she was a good and the best Women in the fort, aged abt 25 years she left a fine infant girl.

${ }^{154}$ Snake Indians. This tribe was so generally known by this term as to almost obscure the family name of Shoshoni. "Alexander Ross is authority for the statement that the name Snake arose from the characteristic of these Indians in quickly concealing themselves when once discovered. They seemed to glide away in the grass, sage brush, and rocks, and disappear with all the subtlety of a serpent." (Chittenden, History of the Fur Trade.) Father De Smet says: "They are called Snakes because in their poverty they are reduced like reptiles to the condition of digging in the ground and seeking nourishment from roots." These Indians at one time occupied western Wyoming, the entire central and southern parts of Idaho, Nevada, and a small strip of Utah west of Great Salt Lake. They were in danger of extermination, at the hands of the Minnetarees and Blackfeet, about the time of Lewis and Clark's expedition. The Snakes were a wandering tribe-necessarily so, as they depended on the buffalo and the salmon for their subsistence. They were excellent horsemen and good warriors, but treacherous. While not openly hostile, they were inveterate beggars and thieves, and considered a nuisance by the traders. They were generally at war with the Crows, Blackfeet, and Utahs, and allies of the Nez Perces and Flatheads. It was in a battle with the Grosventres that Sakakawea was captured by that tribe and traded to the Mandans.

${ }^{166}$ For a sketch of Sakakawea, see Appendix. 
$x^{2} \cdot \frac{1}{2}$

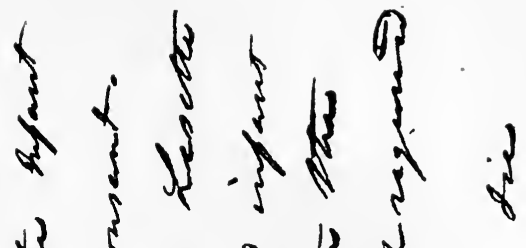
$\min _{n}^{\infty} x^{2} g$ $\left\{\begin{array}{ll}1 & 0 \\ 3 & 1\end{array}\right\}$

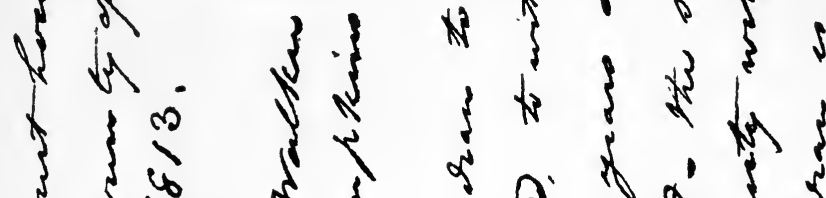

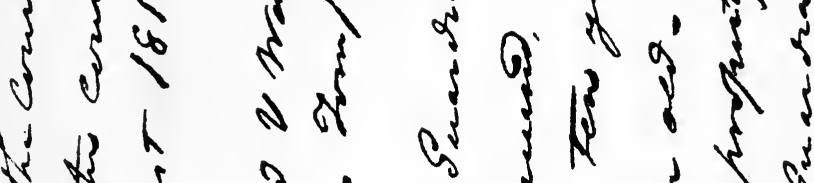

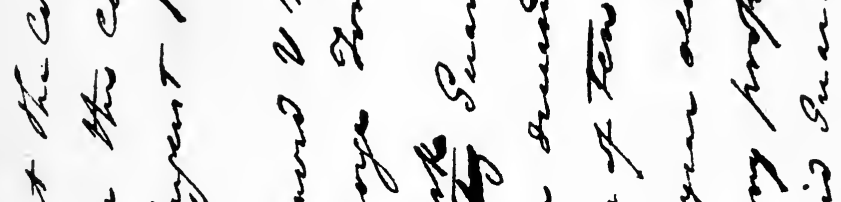

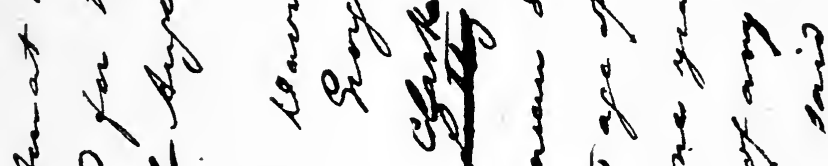

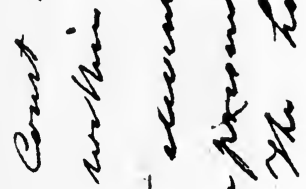
$\left\{-1 \int^{2}\right.$ $2 \sqrt{2}$ o 18 $3 \int^{3} x^{2}$ कर कर कर $4 x$ a 3

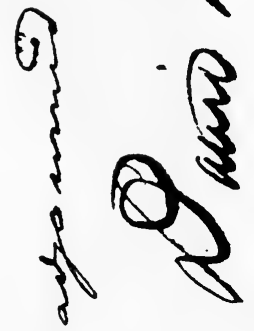
$\left\{\int_{0}^{2} 3 \sqrt{2}\right.$

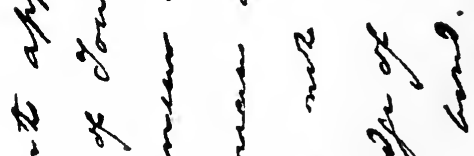

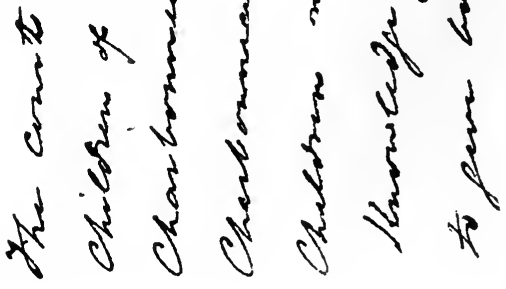


Monday the 2Ist, clear and moderate, paid off our Indian hunters, and they left fort together with the Chajennes for their Village in the Evening, several Rees came from the Mandans, and told us that Immel coming also from the Mandans had been robbed and whipped by the Band of Chajennes at the River Bullet. ${ }^{156}$

Thuesday the 22d fine weather, Garrow and Papin went off early in the Morning to meet Immel, at ro oclock A. M. Immel arrived and the History of the Indians proved to be a Lie, it was true that he had a quarrel with the Chajennes, by refusing them their Demands which he could not comply with, but they did forbcar being only a few to do harm, seeing him on his Guard at noon the Sleighs arrived as also 15 Mandans with them, in the afternoon the three Men which were sent by Mr. M. L. to meet Sanguinette returned without finding him, they found a track of a party of Indians and were afraid to push forward.

Wednesday the 23d fine weather, the Mandans set off for the Rees several Rees arrived in the afternoon, all tranquil and happy in situation.

Thursday the 24th clear and hard wind but

${ }^{156}$ Bullet River-Le Boulet, or Cannon Ball River. It was given this name by Lewis and Clark because "we found round stones in the form of cannon balls." It is a good-sized stream with two main forks, which flow to its junction with the Missouri in Morton County, North Dakota. 
moderate the Rees went off again gave $30 \mathrm{lb}$ flour and $30 \mathrm{lb}$ Tallow to the Boys for regaling themselves tomorrow, in the afternoon the Chajennes Chief returned from the Village he had heard of the Affair of his Village with Immel, he was very sorry fired his Gun backward on entering the house and promised to see every thing arranged to our Satisfaction, this Evening the Boys had a treat of Whisky and made merry fired 3 Guns at Sunset in honor of the approaching night.

friday the $25^{\text {th }}$ fine moderate weather, indeed it looks more like Easter, than Chrismas, were roused by a Salute last Night some Indians were lurking about the fort, and some Men stood guard in the Bastion they saw some thing in the Dark, fired and had Killed an Indian Dog, taking him to be an Indian the Chajennes were afraight to go to their Village and requested a guard, Six Volunteer offered immediately and escorted them untill out of Danger.

Saturday the 26th, at four oclock in the Morning Messrs. M. L., Immel and four Men went to the Sioux, to sound their Sentiments, in the afternoon a party of Mandans arrived at fort with several Rees, and at Sundown our party from the Sioux, they rejected our friendship and will trade as they please, or plunder. fine weather.

Sunday the 27 the weather continuing fine, the Mandans went to their Village, MrM. L. sent 
Colla Glineau along with them, to carry some more Articles to our trader.

Monday the 28th fine weather, made up Equipment for Charbonneau and Woahl to go and trade with the Bigbellies, Baptist went hunting Killed a Calf.

Thuesday the 29th Charbonneau and Woahl set off for their Stations with 2 Men and 4 horses, in the afternoon we had the pleasure to receive an Answer to the Letter sent to Bijou, to the greatest Satisfaction of $\mathrm{Mr} \mathrm{M}$. L., Bijou having traded very well more than expected, Antoine Citoleux ${ }^{157}$ had started with the Indian from below, but could not Keep up walking with him the three which were reported to be Killed were with him, and proved another made History of the Rees.

Wednesday the 30 , fine weather the Sioux went off with their pay a horse and 2 Carrots Tobacco.

Thursday the 3 Ist Rain this Morning, nothing remarkable at Sunset saluted the exile year, the Boys had Whisky and a Dance, all Cares and troubles were forgotten and drowned in oblivity and so concluded again a year with, I may say, a cheerful night.

${ }^{167}$ For sketch of Antoine Citoleux, dit Langevin, see Appendix. 


\section{I8I3}

January the Ist, The new year was ushered in by firing a Salute and paying the Compliment of the Season, every One seemed rejoiced of having lived to see another year, fine moderate weather in the Evening several Rees arrived, they brought a Present for Mr Manuel, but he would not accept it, I took it and paid pretty high.

Saturday the $2 \mathrm{~d}$ fine weather and fresh, nothing to remark.

Sunday the $3 \mathrm{~d}$ fine weather as jesterday, at noon Goshé and a party of Rees arrived, carrying a Pipe to the Chajennes, and came to Council with Mr. M. L. on that Subject.

Monday the $4^{\text {th }}$ fine weather, Goshe went off Cadet Chevalier paid the Debt of Nature at noon he died of a putrid fever.

Thuesday the $5^{\text {th }}$ fine weather and moderate, in the afternoon Antoine Citoleux arrived, in the Evening a Band of Rees headed by Plume D'aigle arrived, carrying a Pipe to Mandans.

Wednesday the 6th the same weather as yesterday the Rees left us and Directly after I found they had stolen our only he Cat Tom, Baptist went hunting at noon Sanguinette, Latour $^{158}$ and Lange ${ }^{159}$ arrived, they had left

${ }^{158}$ Charles Latour. With Charles Sanguinet and Cadet Chevalier he was sent to "find the hunters who were on the Spanish and Arapaos rivers." (Note, appended to company's list of engagés.) Latour was 
their horses $3 \mathbf{I}$ in Number at the little Chajenne fork ${ }^{160}$ prepared for an Expedition to the little Horn. wrote Letters to Lewis \& Lorimier, in the afternoon Baptist brought in the Meat of 3 Cows, cloudy evening.

\section{Thursday the $7^{\text {th }}$ at 4 oclock in the Morning,} Duroche, Machecou and Fouche ${ }^{161}$ left the fort with 3 horses loaden with Tobacco and Powder for to go to the little Horn to $\mathrm{Mr}$ Lewis, cloudy and windy many Rees passed by, at 3 P. M. we saw to our Surprise the three Men which had started this Morning for the little Horn, returning, they reported, they had seen

the son of Amable and Agnes (Menier) Latour of Detroit, and was baptized in Detroit, January 5, 1783. He married, in Florissant, Missouri, January II, I814, a widow with six children. She was Pelagie Billeau, dit Lesparance, widow of Jean Baptiste, and daughter of Francois and Therese (Riviere) Marechal. In the marriage record, Detroit is given as his former residence. Three children were born of this marriage: Agnes, Noel, and Charles, the last-named being the only one wholived to majority. He was in the employ of Lisa and Droullard in 1807 and until the St. Louis Missouri Fur Company was organized. After his marriage Latour took up farming with much success and acquired a small fortune. He died July 24, 1844, on his farm near Florissant, Missouri. His widow died April 20, 1855 , aged 80 years.

${ }^{159}$ Peter Lange, not identified. There was a Joseph Lange with the Northwest Company at Lake Winnepeg in 1804 .

${ }^{160}$ The Little Cheyenne, a prairie stream coming into the Missouri in Potter County, South Dakota, from the north side.

${ }^{161}$ Isaac Foucher. The Foucher family was prominent in Missouri; Pedro Fouché being the Spanish Commandant at New Madrid in 1789. I am somewhat inclined to believe that the Christian name of the man of this expedition was François, although the account-book and the list of engages give it as Isaac. François was with the Missouri Fur Company in 1809 and on August 17, 1813, he with François Rajotte went on a trapping voyage for Chouteau, Cabanne \& Co. This man was living in St. Louis, where he owned some real estate in 1829 . In 1819 he signed a petition in St. Louis to aid in building a college for the "education of the youth." François was the son of Michel and Therese (Leclerc), and married Louise Bertrand, May 21, 1816. In 1825 he was in the Otoe outfit of the American Fur Company. 
something like Men and got scared, they would not go on, returned the Goods, but kept their Equipments for the Vojage which made their tale doubtful, and it seemed they had had no Idea to go, and cheat the Company out of their Goods. Goshé returned from the Chajennes stayed at night.

friday the 8 , Immel went early this Morning with $6 \mathrm{Men}$ after the horses which Sanguinette had left, the Indians Killed 6 Cows for us, and our hunter 2 Bulls and I Deer, the Meat of the Bulls is not good and it is only to have the Hides for covering, cloudy and cold.

Saturday the 9 th hard wind from $N$. W. rain and Squally all Day, cleared up in the Evening and cold.

Sunday the Ioth fine cold weather, nothing to remark.

Monday the IIth fine and moderate, the same.

Thuesday the ri2th, the same - the same.

Wednesday the 13 the same, the Indians Killed 3 Cows towards evening had a Bull chase on the Ice, the poor Animal when he found he was pursued, fell several times, and at last tired could not gett up, - - surrounded by many he awaited his fate patiently cold and cloudy.

Thursday the I4th cloudy and moderate, Indian Killed I Cow a party Mandans camped at fort.

friday the $15^{\text {th }}$ the Present I received the Ist 
instant I had to throw away to the Damage of II4 Dollars on my Side a Lesson I shall not soon forgett, in Evening a party of Chajennes came to fort, carrying a Pipe to the Rees and Sioux, some snow fell, but moderate.

Saturday the 16, fine moderate weather, snow melted away, I took a Walk across the River where two of our Men are cutting firewood, I never saw a finer Spot for Cultivation, a fine timbered Bottom and a beautiful Prairie late in the Evening two Rees stopped and told us that the Sioux had commenced war on them and had Killed a Young Men in their own Village.

Sunday 17 th fine weather, plenty Indians passing by.

Monday the 18 th fine moderate weather, in the afternoon the Chajennes returned, the Rees were preparing for war and summoned all Men which were absent from the Village, at Evening a large party of Women and Children took refuge in the fort, to sleep in Security they were lodged just above us in $\mathbf{5}$ Lodges, and the Men all absent.

Thuesday the roth hard wind and cold, at 8 A. M. Immel \& party arrived with 34 horses, in the afternoon a party of Sioux with the Chief crooked hand arrived with the American Standard flying before them they said they were going to the Chajennes to smoke which was a falsehood, when we first saw them the Rees run to and fro, crying the 
Sioux come to Kill, and made a terrible noise, we traded 32 Robes 20 Beaver, 5 Otter, they went off at their favorite time, at 9 oclock at night, plenty Rees at the fort.

Wednesday the 2oth hard wind \& cloudy all the Rees went to their Village except 2 hunters and their families.

Thursday the 2ist the wind and weather as yesterday Latour, Machecou, Duroche and Joseph Laderoute ${ }^{162}$ were ordered out of the fort, they had made a complot against the adopted Principles of the Company Mr Manuel tried every way to gett them in Employmant but they would neither engage nor hunt nor pay their Debts, Latour had brought 4 horses from the Arepaos Mr M. wanted to buy them against his Debt, no, he offered 300 Dollars wages per year to hunt for the forts or be otherwise employed, they refused, they only wanted to get the necessaries, and Equipments to squander away, and set by the fireside at ease eat our Provision, take out

${ }^{162}$ Joseph Laderoute, dit Casse. This was a common name in St. Louis and Kaskaskia, Illinois. I think I have identified this man as Casse, for Laderoute, dit Casse was with Lisa's expedition which left St. Louis in April, I807. He wintered with Henry's party and returned to St. Louis, August $5, \mathbf{1} 808$. He was also engaged as a hunter in the expedition of 1809 , but was detained at St. Charles by warrant for the non-payment of a debt. However, the Missouri Fur Company paid it and he was released. Two years later, in I8II, he seems to have deserted and left the company before the expiration of his engagement. Joseph Laderoute accompanied Jean Baptiste Trudeau of the Spanish Company in June, 1794, and was in the employ of Gabriel Cerré in 1799. In the St. Louis Cathedral baptisms, there is a record of Emelie Casse, the three-year-old natural daughter of Joseph Laderoute and an Indian, who was baptized April 13, 1816. There were several families in St. Louis with the name of Rolette, dit Laderoute. 
of store when pleased and lett the Company go Destruction, their Character is throughout vicious and Dangerous, the Company looses considerable by them, say about 4000 Dollars. Laderoute wanted to take a girl which Immel had given him, and Immel would not permit her to go in the Situation she was in, high pregnant, but Laderoute wanted to take her by force like a Brute without nourishment and cold Season, the dispute ended by both remaining, one of the Indian hunters got displeased, on Account we would give him no meat for his family, he sold us each Cow for 3 Dollars and then wanted to eat the Meat, avaricious design, last night we saw plenty fires opposite side which induced us to believe that the Sioux had fought with the Chajennes made up an Equipment for Mahas poncas etc.

friday the 22d last Night Laderoute's Girl had a little Girl, cold and cloudy.

Saturday the $23 \mathrm{~d}$, cold and cloudy, our hunters went out and returned with the Meat of 3 Cows, the news from them this day was that a Sioux Chief was Killed by the Rees, and a Ree Woman by the Sioux.

Sunday the 24th Snow and cold, this Day sent the 4 horses promised to Rees Chief for make a hunt.

Monday the 25th clear and cold, nothing to remark.

Thuesday the 26 cloudy and cold, this Evening 
the Men who guarded the horses found two missing supposed to be stolen by Langue de Buche.

Wednesday the $27^{\text {th }}$ clear and cold Sanguinette and a party went hunting, Immel, Papin and another party went to Langue de Buche, which as suspected, had been the Case as were informed that his party had stolen the horses, they returned in afternoon in several parties, one party found an Indian who had stolen a horse this Day close to the fort of Colla Glindeau, and Immel seeing another Savage stealing the Way of him suspected some thing wrong, made up to him, and found the running Mare of $\mathrm{Mr} \mathrm{M}$. L. thus were two more horses rescued their report was that they had found no horses nor Langue de Buche, he himself was gone to the Chajennes probably to trade them away for Meat.

Thursday the 28th Mr Manuel L. and 12 Men went to the Camp of Langue de Buche, to demand the horses, on their arrival they took possession of the Indian fort and made some shan prissoners, they did not find the horses and were told they the horses were out hunting, the Indians began to make overtures and begged, promised to return the horses to fort. - Mr Manuel pitied them and left one Men to receive the horses, who returned in the Evening ( $\mathrm{Mr} \mathrm{M}$. \& party arriving at noon) with only one horse which belonged to Jessaume, the other not given up, this Day fine clear and cold weather. 
Friday the 29th, cloudy in the Morning, cold and Snow Squalls, last night Laderoute and his girl deserted through one of the port holes in the Bastion Garrow went to the Village to see how the Rees were situated, he returned late at night and told the Goshe and his Band wished to come and live at the point above us if we would sent horses to carry their Luggage, Indians and hunters went out to Day but Killed nothing.

Saturday the 3oth clear but very cold, the hunters went out again but returned the weather being to severe.

Sunday the 3 Ist, moderate and clear, Immel, Sanguinette and four Men with 20 horses started for the Village, to bring the Rees this Day our hunters Killed 4 Cows.

Monday the Ist of Febry, clear and fine moderate weather, in the afternoon Immel and party with Goshé and 4 Lodges of his Band arrived, but instead of camping at point took their Lodgings in the fort, hunters were out again to Day and Killed 3 Cows and 2 Deer.

Thuesday the $2 \mathrm{~d}$, fine weather, nothing remarkable.

Wednesday the $3 \mathrm{~d}$ the same, the Rees went out hunting and in the absence of the Men the Women began to quarrel among themselves, and left the fort sack and pack, there being 5 Lodges of wood at the point they went there, but returned about ro oclock in the night, being afraid of the Sioux, three Indians 
came to fort with 4 Cows, the remaining camped out.

Thursday the 4 th fine weather and warm, the 2 stolen horses were brought in, Goshé and his hunting party returned they had Killed 7 Cows. At 4 P. M. I2 Soldiers of the Band of Goshé arrived, thawed very much and plenty water on the Ice.

friday the 5 th, clear and moderate, the Men which came yesterday belonging to Goshe's Band went off again to the Village to bring their families, at noon became cloudy and heavy Squalls towards evening a young men of the Bigbellies of which we had two families in the fort went out hunting on foot for some deer or Elk, and about 8 oclock P. M. we heard the Cry to Arms and two guns fired at the same time which proved to be out of the fort, opening the Door of the fort we found the above Young Men breathing his last, we found him shot in the Belly and Breast his hunt laid a little ways off, he had Killed an Elk and brought only the Calf, a favorite Dish with the Indians we expected a Return and Kept Guards, the Sioux were perpretators of this Act, he died I hour after, blew a hard gale all night

Saturday the 6 th the wind continuing blowing very hard found 2 Arrows in the fort which had been thrown through the Crevices of the Pickets, the Arrows found were of the Sioux Nation, and had been leavelled perhaps at some of us, a singular Circumstance happened 
the Day before with the same young fellow who was Killed, he quarrelled with a Women the wife of a Mandan in the fort, and was going to Kill her, when her husband who was absent at the time of the quarrel, arrived and being informed what had passed, went to him if you want to fight, do it with Men and not women come out and measure your Bow with mine but proved coward, next Day he met his fate. at $2 \mathrm{P}$. M. our hunters brought in 5 Cows \& 2 Calfs, a fine afternoon, late at Evening Le Gross arrived at the fort from the Chajennes, he reported they made plenty Robes, and would come to trade in the Spring.

Sunday the 7 th disagreable and snowing, Immel, Sanguinette, Glineau and Lange went with 8 horses to the Mandans to fetch the Peltries traded with that Nation, Legross went with all the Bravos which were in the fort amounting to 26 to the Village, I made a Census of Indians remaining in the fort and found 65 souls left most Women and Children-_ in the afternoon 2 more Lodges arrived, fine afternoon.

Monday the 8 fine clear weather nothing remarkable.

Thuesday the 9th the same - the same.

Wednesday the ro the same but hard wind Killed I Elk.

Thursday the IIth cloudy and hard winds, cleared up in the afternoon, at 9 o'clock in the Evening we heard several guns firing, and 
directly afterwards 3 Rees young men arrived, who had run away from a fray which they had with the Sioux, they reported that 4 of them were Killed, all Indians in the fort in uproar we watched all night, but nothing occured.

Friday the 12, clear and cold, the refugees reported last evening that a Son of Goshe, with 2 young Men and I Women was Killed, Goshé started, Mr Manuel L. gave him a Blanket I/4 lb Vermillion and 30 Loads of Powder Ball to cover the Corps as customary with the Indians, at ro A. M. the party returned they had found but 2 Corps I Men and I Women, a Child which the Women had was taken prisoner and the son of Goshe had found blind as he is the way in the woods to hid himself, they found him laying among the Brushes, when he heard himself discovered, cried out who is there and finding his friends was rejoiced Goshe gave him the Blankett etc and sent him off in the afternoon Io Chajenne Chiefs arrived and about 150 Rees to go to the Chajennes for Meat.

Saturday the I3th the Chajenne Chief went away seemingly satisfied and the Rees with them Mr Manuel Lisa gave 5 Carrots 4 Twist Tobacco $3 \mathrm{lb}$ Powder and $6 \mathrm{lb}$ Balls as a Present, at 2 P. M. Immel and his party returned from the Mandans with Peltries at 4 P. M. about 50 or 60 Rees arrived from the Village with Plume D'aigle to bury as they 
said their slain brethren-fine weather and moderate.

Sunday the I4th, cloudy and snow squalls, the Rees went off.

Monday the 15 , cloudy and cold, the Rees returned from the Chajennes.

Thuesday the 16th clear and cold, all the Rees which had hitherto staid in the fort went off to their Village being advised by the Chajennes to leave the fort, only 5 Women and 2 Girls remaining, cloudy evening.

Wednesday, the 17 cloudy and hard winds nothing to remark.

Thursday the 18 , clear and very cold, Killed 2 Deer.

friday the 19 ditto-ditto nothing to remark.

Saturday the 20 cloudy and cold, in afternoon Snow Squalls our Sow brought 77 Dead Pigs, a great loss.

Sunday the 21 clear and cold, this day is the coldest we have had this winter, at 12 oclock this Day Charbonneau and I Engagee arrived from the Bigbellies, himself and Woahl had traded out of 492 Plus only 168, the Chief named Borne was thrown off by the Nation only 5 Lodges remaining with him, and had a seperateVillage, he persuaded Charbonneau to come with some Powder $\&^{\mathrm{a}}$ to his Village to trade, he went and took $25 \mathrm{lb}$ Powder and 50 $\mathrm{lb}$ Ball of which he was robbed off when Char- 
bonneau was informed by the Chief Cheveux de Loup who[was] first Chief among them that 4 or 5 Days after his Arrival from hence in December last, 2 Men from the N. W. Company had been with them, they came under pretext to trade dressd Buffaloe Skins, and made some Presents to the Chiefs, and began to harangue against the american traders, told them we would give them nothing, but a little powder, and that they the N. W. Company would furnish them with every thing without Pay if they would go to war, and rob and Kill the Americans, this had the desired effect on Borne, and he made several Speeches to the Nation to that purpose, but being disgraced and not liked he retired without Success, though himself fulfilled his promise to rob, but was afraight to Kill, thus are those Bloodhounds the British constantly employed and do every thing in their Power to annoy and destroy the Americans and their trade, they have nothing to fear on Account and in Respect of our Government, all though in our territories, and in fact our Government does not care to meddle with them, nor how many Citizens are sacrificed by the British influence with the Indians, if there was a fort at the River St Peters ${ }^{163}$ as was promised by

${ }^{108}$ Eight years farther along the United States Government did fulfill its promise. In 1820 the 5 th United States Infantry, under the command of Col. Henry Leavenworth, was sent to establish a military fort at the mouth of the St. Peter's River (now called the Minnesota). The cantonment was first called Fort Anthony, but was later officially given the name of Fort Snelling. The object of this military expedition was the protection of the northwestern frontiers against Indian attacks, and to check the influence of the British traders with the 
Liet Pike ${ }^{164}$ and another in these Parts of the Missouri, it would do infinitively good to hunters and traders, and bring great wealth to the States, but this is out of question, they have a strong Garrison at Bellefontaine, and that is enough, the soldiers parade, eat and drink and spent their time in Idleness, is there any necessity to keep so many idle fellows in a settled Country, they do not even prevent and cannot protect our Settlers about 80 or 90 Miles above, and we have seen outrages committed by the Indians, horrid to relate, there was after the Sheep were destroyed by the Wolves, a small Garrison errected on Salt River, Mississippi ${ }^{165}$ which will do more good than all Bellefontaine, and if one was to

Indians. The movement had a stimulating effect and the fur trade was considerably extended. (See Journal of S. W. Kearny in Missouri Historical Society Collections, Vol. 3, p. 8.)

${ }^{164}$ Zebulon M. Pike was born in Lamberton, New Jersey, January 5 , 1779. After the purchase of the Louisiana Territory, Pike, who was then a lieutenant in the United States Army, was placed in command of an expedition sent to trace the Mississippi River to its source. In 1806-1807 he was engaged in geographical explorations in the Louisiana Territory, and while on this expedition he discovered "Pike's Peak" in the Rocky Mountains. When he reached the Rio Grande he was taken by the Mexicans to Santa Fe and later to Chihuahua, from wlience he returned home. After his return to the United States he was given the rank of major, and a few years later he published a narrative of his two expeditions. He received his appointment as brigadier-general March 12, I813, and on April 27 of that year was killed by the explosion of the magazine at York (now Toronto), Canada . Pike County, Missouri, was named in his honor.

${ }^{16}$ During the winter of $1811-1812$, the settlements on the Salt River and in the Boone district were kept in constant terror by the Indians. Murders were frequent and the settlers suffered all the dreadful effects of Indian warfare. By command of Gov. Benjamin Howard a small fort was erected, early in 1812 , on the Mississippi River about fifteen miles above the mouth of the Salt River, not far from the present site of Hannibal, Missouri. It was garrisoned by a body of regular troops detached from Fort Bellefontaine, under the command of Lieut. John Mason, in whose honor it was called Fort Mason. 
be erected about 500 Leagues up the Missouri it would be very good to Keep the Indians in their Bounds, Provisions are plenty and the other necessaries could be sent by the traders, but it has been frequently the Case, and has been said our Citizens have no Business to go among the Indians to trade but the profits thereof are not considered, and this Branch of Business will never succeed if not protected by Government, to seat of the British Traders. When Charbonneau passed the Chajennes which are above us about 4 Leagues, ${ }^{166}$ they warned him to be cautious and take care of his Life, that they had discovered 27 Men lurking about, supposing to be the Saunies Sioux, he arrived however without accident.

Monday the 22d fine weather and cold some Buffaloe in Sight, 7 Men went across the River to hunt, and returned about noon, having Killed but I Cow 2 Bulls the weather being to cold, to pursue the Buffaloe, at I oclock $45 \mathrm{Mi}$. P. M. we were alarmed by the Cry to $\mathrm{Arms}$, Archambeau ${ }^{167}$ is Killed, and by sorting found us surrounded by Indians on all Sides, out the reach of our Guns, Archambeau was hawling hay with a Sleigh from the other Side, and just on coming on the River he was shot and Killed Immediatly he was a

${ }^{160}$ This distance would bring the Cheyennes' camp about the present Fort Yates, North Dakota.

${ }^{167}$ Louis Archambeau. Probably one of the Canadian family of that name living in Florissant, Missouri, in early days. There are descendants of that family still living in St. Louis County, but I have been unable to learn anything about Louis, or identify him with the several of that name in Tanguay's Dictionnaire. 
very good Men and had been 6 years on the Missouri, we put ourselves immediatly in Defence, and placed two swivels on the Bank of the River, but unfortunaly our Balls did not reach across, and those on this Side Kept out of Reach of our fire, and dare not come to an open Attack, their Numbers was between 4 a 500, they took the Scalp and cut him nearly to pieces, they marched off about 4 oclock, leaving us to lament the Death of fellow Citizen unrevenged, a party of our Men went across to bring the Corps which they found terrible mangled, they brought 29 Arrows which were sticking in his body and a good many more had been brocken to pieces, his Head Broken the Brains scattered about his nose and ears cut off, his teeth Knocked out, and more terrible Deeds which I will not express with my Pen. We mustered in the Evening and found ourselves $26 \mathrm{Men}$ strong, selected Guards for to night, divided in 5 Watches, 4 Men in each and 2 in each Bastion, gave the Boys a Dram and every one was in Readiness for defence to the last Moment our situation in general is not very pleasing at this time menaced by the Sioux, below, and we dare not trust too much to Chajennes above, they have made a vast quantity of Robes and wish to augment the trade we are told and they shewed a Horn which they made which holds 40 Loads of Powder, instead of giving 20 Load for a Plus, ${ }^{168}$

\footnotetext{
${ }^{168}$ Every skin had an established value, with which all traders were acquainted. A first-class beaver skin, worth in the neighborhood of six dollars, was called a "plus."
} 
I hope we will have no Row with them as to the Rees we fear nothing, they are a sett. of lying and good for nothing fellows.

Thuesday the 23d passed a quiet night, and our Guards saw nothing, after Breakfast Immel and four Men went out reconnoitring on swift horses, returned at noon and reported they had found the tracks of the war party and judged by the Size of the Road they had made to have been about 400, the Road went right across the Hills and the party which was stationed above the fort say about 60 had met them at right angles, about 2 Miles west of the fort, we interred the Remains of our poor fellow Citizen Archambeau, and guarded in the afternoon saw some Buffaloe chased on the other Side, supposed by the same Party, we also saw Dogs on the Ice which returned to the Woods at the point above us, and made us certain there was some hid in the Woods, as also by a track which we found, descending the Coast on our Side I Mile below the fort, set guard for the Night had a fine Day but cold and cloudy evening.

Wednesday the 24th passed a tranquil night, but saw some running fires, the Signal of Indians after Battle, 3 Men went to Langue de Buche's Camp to hear of their Situation a fine Day but cold, set all our Dogs out of fort for guard.

Thursday the $25^{\text {th }}$ passed a quiet night, I guarded till 4 oclock in the morning the 3 Men 
went out yesterday did not Return, Dogs out guarding, dark and cloudy evening.

Friday the 26th snowed last night and this Morning we are constant watching in our careful Situation, we hear and see nobody from all around us, and are like Prisoners in Deserts to expect every moment our fate.

At 3 oclock P. M. our 3 Men returned with Machecou, the whites and Indians who camp above us had heard nothing of the fracas which had happened, the Chajennes had the next Day after the affair, 24 horses stolen by the Sioux, undoubtedly the same party who attacked us there Scheme was to plunder the fort, expecting that we would divide and a party would run across the River to rescue the Man which was Killed, and then come between us and plunder and Kill those in the fort. cleared up towards evening and cold.

Saturday the 27 th passed another tranquil Night cloudy at Sunrise, cleared up at 8 A. M. cold weather.

Sunday the 28, Snowed last night and this Morning the most which has fell this Winter about 4 Inches deep, cleared up in the afternoon with cold weather. nothing remarkable these 2 Days past.

Monday the Ist of March, 1813, clear and cold, after dinner Charbonneau and Leclair ${ }^{169}$ set off for their Stations at the Bigbellies took ${ }^{169}$ Joseph Leclaire, or Leclair. There were several Leclaires in St. Louis about this time, one of whom was a free mulatto. 
some Powder and Ball to compleat his Equipment, they were escorted by 5 of our Men, untill he would be out of Danger, at Sunset it began to Snow.

Thuesday the $2 \mathrm{~d}$ a vast deal of snow had fell last night, but was clear and cold in the Morning, cloudy afternoon, at 2 P. M. 7 Men and 2 Women of the Rees arrived at the fort, the first which made their appearance since Goshe left us, 4 Men I Women went to Langue de Buche the others remained.

Wednesday the $3 \mathrm{~d}$, clear and cold, the Indians which arrived yesterday said that the upper Village of the Rees would come this Day to trade, which however proved to be a lie, at noon 7 Rees arrived from above, as also our party which had escorted Charbonneau, with Latour, Machecou, Duroche and Laderoute, 2 Squaws and 3 Children, a party of Men went over the River to cut firewood, had a fine warm Day and cloudy evening.

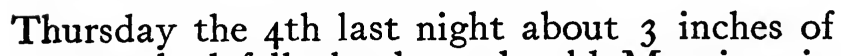
snow had fell cloudy and cold Morning, in the afternoon 4 Mandans arrived from their village on their way to the Rees, no news.

friday the 5 th-Snowstorm last night and continued snowing all this Day, the Mandans pursued their Route.

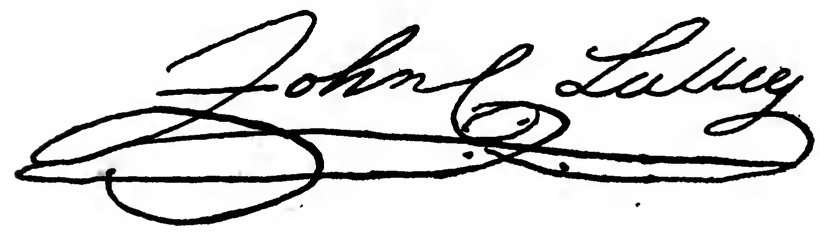




\section{APPENDIX.}

\section{LETTERS FROM CHRISTIAN WILT TO JOHN C. LUTTIG AND JAMES C. MOORE}

Mr. John C. Luttig (Per A. Pourcelli),

St. Louis, June I, I8I 5 .

Dear Sir:

I received your favors by Antoine on the 27th April and should have sent him sooner, had we not been making useless searches for the black Mare in the prairies, the sorrel \& Rone I sold since, the former for $\$ 35$. and the latter for $\$ 30$. which does not pay their keeping-nor am. I yet paid for them. I would therefore advise no more horse speculations-annex your Invoice of sundries Antoine has with him on the Mare-had I the remaining articles you sent for, would have sent you them-but not having them (nor the money to buy them with) prevents my so doing. I conceive this manner of transportation a very unprofitable one-have paid Antoine $\$ 75.17$ for wages at $\$ 25$. per month, which eats up the profit on such small Invoices-would it not be less expensive to send goods down the Mississippi to Cape Girardeau \& let your wagons make a back load of them when you send a load of Fur? I am of opinion it would be cheaper than to send them in a boat \& certainly more expediting \& less dangerous. I have accepted your order in favor of McMines for $\$ 364.22$ which I am obliged to let lie unpaid for want of funds. I must in future protest against your drawing on me in this way. I am yet considerably out in this store \& my other branches of business requiring all the funds I can raise. I expect some few goods by the time you come here with the mulatto girl you have bought, for which purpose I enclose you the $\$ 430$. which I have found difficult raising-the sooner you send her back the better, I am much in want of a girl. I have been pestered to get somebody to pay the freight of peltries sent to Louisville, it might be best to send them here. I fear venison Hams will not bring much in Louisville. I have not yet received the Tallow \& buffalo meat-were [where] venturing is done judiciously it is sometimes commendable, but when you have to pay cash it disappoints me-consider my Dear Luttig was any accident to befall you what would be my losses, were you to have the business scattered. I hope and expect considerable remittances from you shortly, recollect they are long due by promise. I can say little about your 
land speculations but hope your payments have been in goods on which you have laid a good profit. James Kennerly does not think much of that country-you should rent all your lands out, tis bad policy to let them lie idle-the Governor tells me you cannot get a lease without the land is surveyed for a lead mine-the piece of mineral you sent me by Antoine is of an excellent quality, but who is this Colonel in whose name you want the lease. I don't like partners with whom I am not acquainted \& advise you to be careful of strangers-Tar will not bring here more than 50 cts per gallon by the barrel, which will not pay the transportation. I am afraid your Buffaloes will cost a good [deal] by the time they get here, if your fish are the real Trout $\&$ you can put them up to keep, they would answer-better send only one barrel the first time to try them, hope the girl will prove a good one, she is certainly cheap-may be she is stolen property-Racoon from your country will not bring $62 \mathrm{~T} / 2 \mathrm{c}$ in Kentucky, it is only those from the Illinois, one of which is worth two of yours-I am not disposed to buy Racoon nor have I the money-may your blacksmith earn his wages-if you can buy a cheap Boy for trade as cheap as the Girl do so, of about the same age. I cannot send you tumblers, they would inevitably get broken, - the Summons \& Executions I send you-I am glad you sold the Race Mare \& should be more so were my manors to yield the income of some such as there is in England-Paston has been away \& has paid nothing, he is expected shortly-Solomon has not paid the Note $\&$ has sold his Horse-I send in addition to the other articles a coat \& pantaloons, some expect your wedding onesGood assortment of Goods are very scarce here, one or two old Kentucky shopkeepers have come on here-Beef must necessarily come so high with you before it is barreled up, that it could not be afforded so low as from Kentucky, from where immense numbers of Boats have gone to Orleans this Spring which will overstock it-I should prefer those fellows of yours, loading you with Bank notes than their willingness to accompany you through the lower regions-I send you Levantine silk which is much better \& handsomer than changeable-you should get $\$ 4$ the yard for it-if you have nothing for Antoine to do, is it not better to discharge him?

Remain with esteem

Yours to serve,

C. W. 
Mr. John C. Luttig,

St. Louis, July $26, \mathbf{1 8 1 5}$.

Dear Sir:

I have recd. your favor of 3 rd inst. brought I suppose by Smith who I have not seen-yours by Ferguson of the 2nd Inst I also received-I fear those settlements will prevent your friend making remittances without which I cannot think of sending you further supplies. The things you sent by Duncan I fear are lost, he arrived at Louisville about two weeks before Cromwell who had money to pay his freight, not finding any person there to pay him the freight he offered the articles for sale but could not sell \& continued on-this Cromwell wrote me from Louisville he could hear nothing of him up the River, although he made inquiries-I have since heard that Duncan sold the articles. at Vendue for little or nothing-Racoon for about 6 cents-I know not as to the truth of it. Duncan left no Tallow at the mouth of Ohio for me-nor anything else-I cannot agree to your purchasing settlement rights, it will require cash to purchase them afterwards \& I can do better with my funds by applying them to my business-which is suffering for want of them-as you expect to be here soon, we may make some arrangements for further supplies, I have not sufficient dependence in Smith to send by him-wish you to send the girl immediately if you do not come yourself you can send her by some careful person-having been somewhat indisposed of late, I have not called on Dr. Simpson-the person that is to take this letter is at Shope's, I dont know who it is. Remain as ever

Yours to serve

Christian Wilt.

Mr. James Moore,

St. Louis, July 3oth, 1815 .

Dear Sir:

I have received your favor of July 2oth by your son-with sundry books and papers announcing the death of John C. Luttig who had my business in charge, so far as selling of goods and making me remittances for them. His death to me is a considerable misfortune \& for your friendly intercession in taking care of the store \&cc. \& in advising me thereof accept my sincere thanks. I shall as soon as possible send a person to close the business \& will thank you until that person arrives to request A. Pourcelli to remain there-none of the goods 
must be allowed to be taken until said person arrives. Any future services you may render me in the business will be remembered by me. In haste

Remain very respectfully your most obedient servant,

Christian Wilt.

\section{SAKAKAWEA}

SAKAKawEa (or Sacajawea, as she is better known), the Snake squaw of Charbonneau, the guide and interpreter for Lewis and Clark, has been idealized by artist and sculptor, by poet, fiction writer, and historian. Some writers have claimed that without her guidance and assistance the expedition of Lewis and Clark would have failed; and still others have said that her importance has been exaggerated, and that she was of no particular assistance, except to perform feminine duties, such as the mending of the moccasins. Choose what accounts we may, it will be agreed by all that the mention of this expedition immediately brings to mind the part which this lone woman played. The leaders of that expedition have indicated that no member of the party gave more effective service, and she seems to have been the direct means on several occasions of overcoming seemingly insurmountable obstacles. Her sacrifices were many, and they seem quite pathetic when one considers that she was but a child in years.

It would be superfluous to tell the story of her early life, her capture by the Grosventre Indians, when she was about ten years old, the barter to Charbonneau and her subsequent marriage to him; or to recount in detail the part she took in that famous expedition-everyone is familiar with it. The question here is, What are the points of contrast between this journal and the various biographies of this conspicuous woman of the Indians?

It may be interesting first to note that there has been much discussion and argument as to the spelling and proper pronunciation of her name. I am choosing the version of Dr. Washington Matthews, a recognized authority on the ethnology and philology of the Hidatsa Indians, he having published a grammar and dictionary thereof; and of Rev. C. L. Hall, who lived among this tribe for thirty years.

According to Rev. C. L. Hall, Sacajawea, the form which has been so generally used, is a Shoshoni word, meaning "Boat-launcher." His theory is that "while her captors gave her a name which may have 
been a translation of her Shoshoni name, it is more likely to have been entirely different. A stranger coming among the Grosventre tribe, or any tribe of Indians that $I$ know, received at once a name such as may suit their fancy." He therefore concludes that the name is properly Sakakawea, which in the Hidatsa language of the Grosventre is "Bird Woman." She has always been referred to as the Bird Woman, and not as the Boat-launcher, as Sacajawea is interpreted.

The journal here published differs from other accounts as to the time of her death. It describes the wife of Charbonneau, a Snake squaw, as having died December 20, I8I2. Charbonneau probably had two Snake wives, as "two squaw prisoners from the Rock Mountains and purchased by Charbonneau" visited the winter camp of Lewis and Clark at the Mandan village. One, of course, was the Bird Woman, and James Schultz says that the name of the other was Otter Woman, and that she died shortly after the return of the expedition.

Brackenridge, in his journal of a voyage up the Missouri in 1811 , tells us that he met "a Frenchman named Charbonet and his Indian wife, who had accompanied Lewis and Clark to the Pacific. The woman, a good creature, of a mild and gentle disposition, greatly attached to the whites, whose manners and dress she tries to imitate, but she had become sickly and longed to revisit her native country; her husband also, who had spent many years amongst the Indians, was become weary of a civilized life."

Several times, we are informed by the journals of Lewis and Clark, Sakakawea was dangerously ill. It is not unlikely that the hardships this frail child-woman endured following her capture, and again on that long journey to the Far West, shortened her life, and on that "clear and moderate Sunday," December 20th, 1812, she died, leaving a fine infant girl, called Lizette, as well as the boy Toussaint. Luttig, in his laconic way, says she was a good woman-the best in the Fort. A characterization given her by all historians.

Luttig, who seems to have had nothing but contempt for Charbonneau, brought the infant girl down to St. Louis in June, 1813, and possibly Toussaint also, although the latter may have been left at St. Louis in 1811 , when Charbonneau and the Bird Woman returned to the Mandan village. On the IIth day of August, 1813, Luttig applied to the Orphans' Court at St. Louis for appointment as guardian of the infant children of Toussaint Charbonneau, deceased; namely, Toussaint, a boy about ten years old, and a girl, Lizette, about one 
year old. Whether he ever served as such there is no record, for the one entry in the Court's minutes shows that the name John C. Luttig was crossed out and William Clark substituted. (See facsimile of court record.) My conjecture is that Luttig, knowing the fondness of Gov. Clark for Charbonneau and his family, brought one or both of the children to St. Louis after the death of Sakakawea and the disappearance of Charbonneau. Upon his arrival in St. Louis, Clark was absent from the town, so Luttig made application for guardianship. Gov. Clask would have come closer to Toussaint's age in making the application, wherein Luttig missed it about two years.

Sakakawea is known to have had a boy by Charbonneau, about eight years of age at this time, and it is also known that she would have been approximately twenty-five years of age in 1812 , when Luttig recorded the death of the Snake squaw of Charbonneau. This and other things point to Sakakawea as the Indian wife referred to. In passing it should be recalled that Charbonneau was, in fact, not dead at that time.

In Gov. Clark's letter of August 20, I806, he clearly mentions two boys, children of Charbonneau. One he refers to as "your little son (my boy Pomp)" and the other he calls "my little dancing boy Batiest." The dancing boy was too old to be the child of Sakakawea whose birthday has been established. Therefore Baptiste and Toussaint are not one and the same individual. Jean Baptiste Charbonneau was most likcly the Baptiste mentioned in this letter and the son of Charbonneau by one of his other wives, who with her child was at the Mandan Fort in the winter of 1804-1805. The accounts of Clark, as Superintendent of Indian Affairs, for 1820 , show that tuition was paid that year to J. E. Welch for one J. B. Charbonneau, and to Francis Neil for one Toussaint Charbonneau, in each case designated as halfIndian boys. Rev. Mr. Welch was a Baptist minister who boarded and educated Indians and half-Indians, while Rev. Mr. Neil, a Catholic priest, conducted a school for boys, which was the predecessor of the St. Louis University. This Toussaint was unquestionably not the interpreter, as one author has suggested.

Almost every traveller and trader, clerk and bourgeois, who published accounts of visits up the Missouri River, or wrote letters of the events at the various trading-posts, after the Lewis and Clark expedition and up to 1839 , mentioned Charbonneau. Surely, in view of the important part taken by the Bird Woman in the exploration of the 
West, reference would have been made to her by some of them, if she were living at the time.

Prior to the discovery of this journal, nothing was definitely known of the whereabouts of the Bird Woman subsequent to 1811 , when Brackenridge met her. Although Hosmer quotes an old interpreter at Fort Berthold to the effect that she and her husband perished in the small-pox epidemic which was so fatal to the Mandan nation in 1837 , he questions the truth of the account.

These monuments and markers have been erected to the memory of the Bird Woman:

Statue in bronze at Portland, Oregon, unveiled at the Portland Exposition. It was erected with the contributions of the women of the Northwest, and was designed by Alice Cooper. It marks the western terminus of that eventful expedition.

Boulder with bronze tablet at Three Forks, erected by the Montana Daughters of the American Revolution.

Monument with bronze tablet inserted at Armstead, Montana. It was near this spot, at the Two Forks, or Jefferson Forks, as it is sometimes called, that the exploring party met members of Sakakawea's own tribe, the Shoshoni, and from them secured horses necessary to cross the Great Divide, without which they never would have been able to complete the journey. This monument was also erected by the Montana Daughters of the American Revolution.

Cement shaft erected in Wyoming over the grave of the woman claimed by Dr. Hebard to have been Sakakawea.

The United States Geological Survey gave her name to the great peak in the Bridger range, overlooking the spot where she was captured, and where she later pointed out the pass over the mountains.

Statue in bronze on the site of the old Mandan village, now Bismarck, marking the beginning of the great journey, erected by contributions from the women and children of North Dakota.

There stood in the grounds of the Louisiana Purchase Exposition, at St. Louis, a beautiful statue of Sakakawea, designed by Bruno Louis Zimm, a photograph of which is reproduced in this book.

\section{TOUSSAINT CHARBONNEAU}

Toussaint Charbonneav was conspicuous as an interpreter in the fur trade, and through his employment, from 1819 to 1839 , by every United States Indian Agent and sub-agent of the Mandan and Up- 
per Missouri Indian tribes. His importance to the Government is shown by the salaries allotted to him, which varied from $\$ 200$ to $\$ 400$ per annum, the latter sum equalling that paid to most of the sub-agents. That he was faithful and competent is indicated by the long term of his employment by the Government. He was known to Lewis and Clark, Prince Maximilian, Henry M. Brackenridge, John Bradbury, Generals Henry Atkinson, and Stephen W. Kearny, from all of whom we have accounts of him, and to every fur trader and traveller of the early days in the Upper Missouri regions.

The prominent incident in the life of Charbonneau is his purchase of an Indian girl, about ten years old, to be his slave. Later he married her, and as his wife she became famous as a faithful and efficient guide of the Lewis and Clark expedition. Her name was Sakakawea, and she was otherwise known as the Bird Woman, about whom much has been written, and to whose memory monuments have been builded.

Charbonneau was born in Canada about 1759, of French lineage. Both his given and surname are very common among the French of Canada. The record of his first employment reveals him as a trader with the Northwest Company at Pine Fort on the Assiniboine, in the year 1793-94. Two years later he was with the Minnetarees at their central village on the Knife River, called Metaharta. Lewis and Clark found him at this place in the winter of $1804-05$. The previous year he was in charge of Fort Pembina with Alexander Henry, from whom we get the earliest mention of him.

Prince Maximilian, in 1833 , recorded the fact that Charbonneau had lived among the Mandan Indians for thirty-seven years, and gives the various names by which he was known to the Indians, which he interprets from the Indian languages as follows: "Chief of the little village"; "The man who possesses many gourds"; "The great horse from abroad"; "The forest bear."

An editor of the journals of Lewis and Clark speaks in very uncomplimentary terms of Charbonneau, using this language: "After reading the pages of Lewis and Clark's journals, one has little respect for Charbonneau's qualities, either mental or moral. It is to be regretted that Maximilian relied so much upon the testimony of this interpreter in his account of the Mandan and Minnetaree Indians."

Indeed, Capt. Lewis, in his report, says of him that he was "a man of no peculiar merit, was useful as an interpreter only, in which capacity he discharged his duties with good faith." As he was employed only as an interpreter, this record of having discharged his duties with 
good faith would seem a pretty fair recommendation; but more than this, we have the letter of Gen. Clark, written to Charbonneau of August 20, 1806. In this he says, among other things: "Your present situation with the Indians gives me some concern. I wish now that I had advised you to come on with me to Illinois, where it most probably would be in my power to put you in some way to do something for yourself. * * * You have been a long time with me, and have conducted yourself in such a manner as to gain my friendship."

Luttig, in his journal, twice speaks of Charbonneau in a rather disparaging manner in connection with certain incidents, indicating in one place that he had been guilty of exaggeration and cowardice, and in another that he gave wild accounts calculated to excite fear among the engagés. Here he also includes another interpreter, named Jusseaume, and says that both "ought to be hung." Other incidents, however, mentioned in the journal, indicate a reliance placed upon Charbonneau, and also show that he was not a coward. It may be that Luttig shared that common suspicion which men on these expeditions had for interpreters, who were on friendly terms with the Indians and spoke in a language which could not be understood by the trappers. His winning ways were evidently not understood by his critics. William Laidlaw, in a letter to James Kipp, dated Fort Pierre, January 14, 1834, says: "I am much surprised at your taking old Charbonneau into favor after showing so much ingratitude upon all occasions. The old knave, what does he say for himself?"

Charbonneau had many friends among the traders, Indian agents and travellers of the West. In letter-books and manuscripts to be found among the archives of the Missouri Historical Society, as well as in many of the published narratives of travellers, are many favorable references to him. Mr. O. L. Wheeler, author of The Trail of Lewis and Clark, says he was a most picturesque and unique character, and a man of fairly commendable traits, considering his environment. Francois Antoine Larocque of the Northwest Company speaks very favorably of him. Maximilian refers to Charbonneau in a complimentary manner and gives him credit for much valuable information on the Mandans and customs of the different tribes on the Upper Missouri. To be sure, Maximilian has been criticized for placing too much reliance on Charbonneau's accounts, but certainly one of the incidents which he gives much attention to on the authority of Charbonneau is verified by Gen. Clark in his diary of 1826 . 
From manuscripts and deeds recorded in St. Louis some disconnected facts are reiterated in these notes, for whatever they may be worth, in connection with Charbonneau's life: On March 26, 1811, Charbonneau conveyed to William Clark, for the consideration of $\$ 100.00$, a piece of land on the Missouri River, situated in St. Ferdinand Township, which land had been conveyed to him on October $3 \mathrm{c}$, 1810 . This instrument indicates that Charbonneau bought the land with a view to settling down to civilized life, but, becoming weary of it, as Brackenridge tells us, transferred his property to Clark and returned to the Mandans. The witness to this deed was François Robidou, a mutual friend of Gen. Clark and Charbonneau. In the manuscript ccllection of Auguste Chouteau it is noted that Charbonneau purchased of him, on March 23, 1811, fifty pounds of bequit (biscuit), the hard-tack of those days.

American State Papers, Foreign Relations, Vol. 4, p. 210 , show an affidavit made by Charbonneau at St. Louis, on December 8, 1817, concerning the imprisonment of American citizens in Mexico. In this affidavit he states that he is of lawful age; that in the month of July, 1816, he engaged himself to Julius De Mun, of the firm of Auguste P. Chouteau \& Company, to go from St. Louis on a trading voyage along the rivers Arkansas and Platte; that Chouteau \& Company had agreed to pay him for said voyage the sum of two hundred dollars; that he stayed with the company from the month of July, the time of their starting from St. Louis, until July in 1817. He signed the affidavit with his mark.

In the unpublished journal of Gen. Henry Atkinson, of 1825 , are several references to Charbonneau; one to the effect that he (his name is there spelled Shabano) and his wife and her brother were at the Mandan village. This was not the Bird Woman, as she died in 1812; and her brother, being a Shoshoni Indian, would not likely have been among the Mandans.

Maj. Stephen Kearny, in his journal of August II, 1825, describes Charbonneau Creek as having been named for a Frenchman who accompanied Lewis and Clark across the mountains, and whom he saw at the Mandans, residing as a trader among them.

Capt. R. Holmes of the United States Army refers to "old Charboneau," whom he met in 1833 , in a party of white men in the mountains. He says that Charbonneau never carried arms, his knife being his only weapon.

In a letter from Maj. D. D. Mitchell to W. N. Fulkerson, Indian 
Agent for the Mandans, dated June 10, 1836 , reporting the details of a battle between the Grosventres and Mandans of the little village against the Yanktonai band of the Sioux, states that "old Charbono" had a narrow escape, two balls having passed through his hat.

Much has been said about the meager compensation paid to Charbonneau by the Government for the services of his wife and himself. From the report of Capt. Lewis we have the statement that he received as compensation $\$ 25.00$ per month while in service, which extended from the time of the departure of the expedition from the Mandan village on April 7, r805, until he returned to that place in August, 1806. This item is often referred to, but no mention has ever been made of the fact that Charbonneau received, in addition to the cash compensation, the same bounty land grant of 320 acres given to the other men who served as privates of that expedition.

Accounts heretofore published cover Charbonneau's career only to the year 1838 . There is in the Indian Department at Washington, D. C., an interesting letter from Joshua Pilcher, Superintendent of Indian Affairs, a copy of which is given in this Appendix. In this letter, dated St. Louis, August 26, 1839, Charbonneau is pictured as tottering under the infirmities of eighty years, without a doilar to support him and seeking to collect his salary as interpreter for the Mandan agency for the first and second quarters of that year. It shows that an order had been made for his dismissal, and calls attention to the fact that he served some time in ignorance of the order. It will be remembered that the Mandan Indians had been almost entirely wiped out by an epidemic of smallpox, and there was probably no longer any special need for an interpreter at that agency.

A Toussaint Charbonneau of Carondelet, St. Louis County, made entry of land in Richwoods Township, Washington County, Missouri, in 1822 , and settled on the land. This man has lately been confused with the Charbonneau of Lewis and Clark fame, and many of his descendants are erroneously under the impression that the interpreter was their ancestor. The tombstone over the grave of Toussaint Charvonneau at Richwoods gives the date of his birth as of March I, I78r, and his death as of February 19, 1866. Charbonneau of the Lewis and Clark expedition was connected with the Northwest Company in 1793 , when the Richwoods man was only twelve years old. There is a deed, dated June 5,1848 , from Toussaint Charbonneau of Richwoods and his wife, Marie L. Laviolette, a French woman, recorded in St. Louis, 
which recites, among other things, that he was living in Washington County, Missouri.

The children of Charbonneau and the Bird Woman, of whom we have record, were Toussaint and Lizette. It is known that the former was educated by the Catholic priest, Rev. F. Neil, in St. Louis. In 1830 there was a Charbonneau with a party of hunters and trappers in Idaho, and Nathaniel Wyeth also mentions meeting a Charbonneau (a half-breed) with Jim Bridger at Fort Bridger in August, 1832. Fremont found one "Chabonard" camped about nine miles above the mouth of Bijou Fork in July, 1842. Sage, in his Rocky Mountain Life (Boston, 1857, p. 206), tells of meeting a half-breed fur trader named Chabonard in 1841, upon the White River, and later, in 1842, on an island in the Platte. Chabonard was in the employ of Bent \& St. Vrain, and in charge of the camp, and "proved to be a gentleman of superior information." He had acquired a classic education and could converse quite fluently in German, Spanish, French, and English, as well as several Indian languages. His mind also was well stored with choice reading and enriched by extensive travel and observation. This may have been one of Charbonneau's sons. In Gov. Clark's expense accounts for the half-Indian boys named Charbonneau there is listed: one Roman history, Scott's Lessons, one dictionary, slate and pencils, paper and quills. The daughter or granddaughter of Charbonneau is mentioned by Lean Wolf, an old Hidatsa Indian, as having died in 1837 during the smallpox epidemic.

On April 23, 1843, there was baptized at Westport, Missouri, Victoire Vertifeuille, the daughter of Joseph Vertifeuille and Elizabeth Carboneau. Perhaps Elizabeth Carboneau was Lizette Charbonneau, the daughter of Toussaint Charbonneau and Sakakawea. -

\section{LETTER FROM MAJOR JOSHUA PILCHER TO COMMISSIONQER OF INDIAN AFFAIRS}

Superintend.y of Indian Affs. St. Louis, Augt. 26, 1839.

Sir:

On the 2rst inst. Toussaint Charbonneau, the late Mandan Interpreter, arrived here from the Mandan villages, a distance of 1600 miles, and came into the office, tottering under the infirmities of 80 winters, 
without a dollar to support him, to ask what appeared to me to be nothing more than just, and I accordingly have paid his salary as Interpreter for the Mandan sub-agency, for the Ist \& $2 \mathrm{~d}$ quarters of this year, with the understanding that his services are no longer required. This man has been a faithful servant of the Governmentthough in a humble capacity. He figured conspicuously in the expedition of Lewis and Clark to the Pacific, and rendered much service. For the last fifteen years, he has been employed as the Government interpreter at the Mandans, and never received notice of the intention of the Department to dispense with his services, until some time in July, in consequence of the remote situation of the post. Under these circumstances I thought, and still think it but right that he should be paid, and believe it will meet your sanction, to be charged, (as there has been no allottment for that sub-agency), to the contingent account of the District.

$$
\begin{aligned}
& \text { I am, } \\
& \text { Sir, } \\
& \quad \begin{array}{l}
\text { Your mo. ob. st. } \\
\text { JoshuA Pilcher, Supr. In. Affs. }
\end{array}
\end{aligned}
$$

T. Hartley Crawford, Esq.,

Commr. Ind. Affs.

Indorsement:

O. I. A. Upp. Mo. Sat. Feb. 24,

Maj. Joshua Pilcher,

Saint Louis, Aug. 26, 1839.

Toussaint Charbonneau, late Mandan Interpreter, being 80 years old \& pennyless, has paid his salary for Ist \& $2 \mathrm{~d}$ qr. of '39-as the notice of discontinuance did not reach him till some time in July.

Ought to be allowed.

Rev. Sept. 6, 1839.

File.

\section{MANUEL LISA}

MANUEL LisA, one of the most conspicuous of the Indian traders and merchants in St. Louis, was born in Lower Louisiana about 1776, 
and was the son of Cristobal de Lisa, a native of the town of Murcia, Spain, and Maria Ignacia Rodriguez. In his early youth he was attracted to the Indian trade and made several voyages from New Orleans to the Wabash. In $\mathbf{I} 799$ he came to St. Louis and started in trade with the Osage nation, of which he obtained a monopoly from the Spanish Government. His premier voyage up the Missouri River was in 1807 and from that time until his death he was the recognized leader in the Missouri River trade. He was twice married to white women; first to Mary Charles, and after her death in 1818 he married Mary Hempstead Keeney, daughter of Stephen Hempstead. His only living descendants are the children of his daughter Rosalie, whose mother was an Omaha. He died in St. Louis, August 12, 1820, after a few days' illness. His widow survived him fifty years, and died at Galena, Illinois, September 3, I869. For an extended biography of this famous character, see Douglas, Manuel Lisa, Missouri Historical Society Collections, $3: 233,267$.

\section{TRANSLATION OF LETTER OF MANUEL LISA.}

To the Spaniards of New Mexico:

Fort Manuel, Sept. 8, 1812.

My dear Sirs: Ever since my first journey among the forks of the Missouri, nine hundred leagues from my domicile, I have desired to find an opportunity to communicate with my [com]patriots, the Spaniards. I have had hunters to the number of twenty-three who have gone to the Arapaho nation. Last year they came to my Fort Mandanne, where I equipped them anew to return to the place whence they had come. They are the ones who informed me that the Spaniards of Mexico were coming every year to trade with the Arapahos. Therefore I gave to a certain Juan Baptista Champlin, an honorable young man, and Juan Baptista Lafargue some goods for the purpose of trading with you, admonishing them that it must not be to the prejudice of the Government, nor contrary to its laws.

Since some of my hunters should come this year to meet me at this establishment on the Missouri, and since up to the present I have not had any news [of them], I have decided to send one of my trusted servants, Don Carlos Sanguinet, with two engages, to let them know where they should come out with their peltry; and for the same purpose, with the same Sanguinet, I sent ten men to the Petite Corne, which 
empties into the Rio Amarillo, and this into the Missouri, the entry of the Petite Corne being two hundred and twenty-five leagues from this establishment, with orders to establish [a post at] that place, as nearer for my hunters.

I have especially instructed Don Carlos Sanguinet to arrange that this letter of mine should fall into the hands of some Spaniard who may be worthy to communicate with me on those honorable principles, and in no other manner, my desire being to engage in business and open up a new commerce, which might easily be done. With this in view, and as director of the Missouri Fur Company, I propose to you gentlemen that if you wish to trade and deal with me, for whatever quantity of goods it may be, I will obligate myself to fill each year any bill of goods which shall be given me, and all shall be delivered (as stipulated) both as to quality and as to quantity, at the place nearest and most convenient for both parties, to your satisfaction, after we shall have agreed on the chosen place.

In case any of you should wish to come with Don Carlos Sanguinet to this my establishment to communicate and trade with me, you will be received and treated with great pleasure and satisfaction, and assured of a sufficient escort, agreeable to you, up to the time you return to your country. I commend Don Carlos Sanguinet to you as a trustworthy and honorable man, and, if you are agreed, you may confide in him without any fear whatever; and in case you do not come in person, I shall be obliged to you if you will write to me. Meanwhile, awaiting you, I beg God to spare you many years.

Your most attentive and faithful servant,

Triplicate.

Manuel Lisa (Rubric).

(The original of this letter is in the Archives of Chihuahua, and published for the first time by Herbert E. Bolton in the Southwestern Historical Quarterly, Vol. XVII., p. 6r.)

MICHAEL E. IMMELL

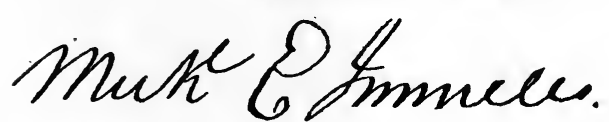

Michael E. IMMELL was one of the bravest and most resourceful men in the fur trade. He was a native of Chambersburg, Pennsylvania, but the year of his birth is unknown. He came to St. Louis in the 
early part of 1804 , and later became a member of the First Infantry, commanded by Col. Thomas Hunt. He was appointed ensign June 10, 1807 , and on October 10, 1808, was promoted to second lieutenant; two weeks later he resigned from the Army. He was stationed at Fort Bellefontaine during most of his army service, although for a

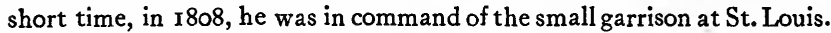
In 1809 he went up the Missouri River with the Missouri Fur Company, and soon became Lisa's most trusted lieutenant. There is no record of his having returned to St. Louis after this departure. In I810 he joined fortunes with Jean Baptiste Vallé as a free hunter on the Upper Missouri. Immell was at Fort Osage in March, 1817, where he gave a report of some petrified mammoth bones and cedar which he saw at a "lake near the waters of Qui Courre River". This information was afterwards published in the Missouri Gazette, April 12, 1817. When Lisa was deprived of the control and management of the affairs of Cabanne \& Company on the Missouri River and its waters, in February, 1819, Michael E. Immell, who was at Fort Lisa, was appointed to take command jo intly with George Kennerly. While in command later, with Robert Jones, of an expedition on the Yellowstone, he was killed; being literally cut to pieces in battle with the Blackfeet, May 31, 1823. Major O'Fallon, United States Agent, in his report of this conflict to Gen. Clark, July 3, 1823, speaks of Immell in these words: "Immell has been a long time on this river, first as an officer in the U. S. Army, since as a trader of some distinction. He was in some respects an extraordinary man; he was brave, uncommonly large and of great muscular strength, and, when timely apprised of danger, a host in himself."
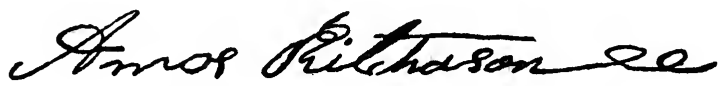

Amos Richardson came from Kentucky to Missouri before 1803 and settled in the District of St. Louis at a point which is now St. John's Township of Franklin County. He was the fourth child of Daniel and Nancy Richardson, who claimed land at Point Labadie, in Franklin County. Amos Richardson was a Syndic under Gov. Delassus, whose report of him states: "I think him a proper man for public business, and since hia appointment he has always borne himself ear- 
nestly in all matters." He was in the employ of Sanguinet and Robidou from 1804-1809, and later with Auguste Chouteau, as a trapper, Bradbury, in his travels of 1809-1810, met Richardson at the Arikara village in July, I810, and he asked permission to travel down the river with him to St. Louis. Four years without seeing a single white man's house made him very eager to leave the Indian country. Then, too, he suffered great hardship, including a severe arrow wound, which gave him considerable pain. During the descent of the river he told Bradbury that he would never again go back to the hunting life. Three weeks after his arrival in the settlements, when Bradbury was ready to make his trip up the Arkansas, Richardson asked to join him, When Bradbury expressed surprise at so sudden a change in his intentions, he replied: "I find so much deceit and selfishness among white men that I have already tired of them. The arrowhead, which is not yet extracted, pains me when I chop wood, whiskey I can't drink and bread and salt I don't care about. I will go again among the Indians." However, after his return from the Arkansas he went back to his home, which was close to that of John Colter of Lewis and Clark fame. The Colters and the Richardsons were very good friends, and upon the death of Colter, Daniel Richardson was appointed administrator of the estate. After the death of their father Daniel, Amos and his brother Richard were appointed administrators to close up the estate of John Colter. Amos Richardson married and was living in Franklin County in 1835, the last date of which we have any record of him. He, as well as other members of his family, were prosperous farmers of Franklin County, Missouri.

\section{COLONEL ELI B. GLEMSON}

Eli B. Clemson was a native of Pennsylvania and he entered the United States Army from that State. His commission as second lieutenant of the Ist Infantry was issued March 3, 1799, and first lieutenant April 30, 1800; at these times he was stationed at Detroit. Lieutenant Clemson was promoted to a captaincy March 4, 1807; major, January 20, 1813; lieutenant-colonel of the 16th Infantry, March 9, 1814; and honorably discharged June 15, 1815. The following year he was appointed Commissioner of Issues at St. Louis, which post he resigned December I, 1819. In 1807 Captain Clemson was appointed, at the suggestion of his friend Frederick Bates, justice of the peace for the town- 
ship of St. Ferdinand, District of St. Louis. Colonel Clemson was a most capable man, and his interests and occupations covered many fields.

As commander of Fort Osage in 1808, Major Clemson mustered into the United States service a body of militia to convoy the Mandan chief on his return to the Mandan village. Fort Clemson, situated near Loutre Island, St. Charles County, was erected and named in his honor during the War of 1812 . For a number of years prior to and after the War of 1812 he was stationed at Fort Bellefontaine and invested largely in St. Louis real estate, realizing therefrom a handsome profit. In 1817 he purchased from Judge Lucas a block of ground covering Olive, Locust, Sixth and Seventh Streets, on which he built a large frame dwelling and lived there for some time. This block is now the site of a combined department store and office building. In about 1820 he sald out his interests in St. Louis and went East. Returning to the West in a few years, he located in Lebanon, St. Clair County, Illinois, and for a time operated a line of stage and mail coaches between Vincennes and St. Louis. Later he went to Carlyle in that State and embarked in the mercantile business. In 1832 he moved to Carrollton, Illinois, and again engaged in the transportation business between Springfield and St. Louis. A few years afterwards he took up farming at Caledonia (now called Olmstead), Illinois, and served as postmaster of that place. He was the projector of the town of $\mathrm{Na}$ poleon and agent for the Winnebago Land Company. His last occupation was clerk of Pulaski County Court, which position he held at the time of his death, June 25, 1846.

Colon el Clemson was twice married. First to Miss Ann Marie Oliver of New Brunswick, New York, on April 9, 1811. Of this marriage four children were born: Henry A., who was an officer in the United States Navy and was lost during the siege of Vera Cruz in the Mexican War when the United States brig Somers capsized; James Y.; Frederick W.; and Mary C., who married Mr. Olden of Princeton, New Jersey. Mrs. Clemson died in 1832, and Colonel Clemson afterwards married Mrs. Fsther Daniels Riddle, the widow of Captain James Riddle, August II, 1836. Two children were born of this marriage: Aaron B. and Theodosia B. The second Mrs. Clemson died in 1864. Colonel Clemson's son James Y. married Henriette McDonald; from her was obtained the data concerning the Colonel's career in Illinois. 
FRANCOIS ROBIDOU

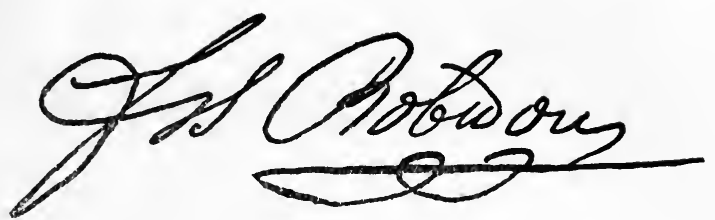

Francors RoBidou, the third son of Joseph and Catherine (Rollet, dit Laderoute) Robidou, was born in St. Louis, September 24, 1788. He was married in 1807 to Therese Bienvenue Delisle, daughter of Jean Baptiste and Cecile (La Rose) Delisle. Mrs. Robidou died in 1833, at which time six children, born of this marriage, were living: Therese, François, Antoine, Jean Baptiste, Marie, and Cecile. Fransois Robidou received a very good education, and was prominently identified with the social and civic history of St. Louis. He was one of the signers of the petition for incorporating St. Louis in 1809. Francois and his brother Joseph were closely associated together all their lives. From an early date they made many trips up the Missouri River as trappers and hunters, and later as free traders. When Joseph was persuaded to remain in St. Louis and paid to cease his trade with the Indians, the two brothers opened up a confectionery shop in St. Louis. Their father had erected one of the first stone bake-ovens in St. Louis, in order to supply the Indian trade, as well as the residents, with bread. When they resumed their former occupation as Indian traders, Joseph remained in the Black Snake Hills (now St. Joseph, Missouri), while François went further up the Missouri River, or across the plains to the mountains, to hunt and trap. After taking up their residence at St. Joseph, Missouri, François seems to have become the lesser light, and his deeds are not recorded in the history of that community. This was due probably to the fact that Joseph was the leader and dictator, and François the follower, the hunter and trapper. I find no record of a second marriage, nor of the death of François. His great-nephew, Louis R. Robidoux of Kansas City, tells me that the family tradition indicates that François died on the plains of Nebraska on May 30, 1857. The Probate Court records of Buchanan County show that letters of administration were taken out on the estate of one François Robidoux on April I I, 1856, and also that he died intestate, leaving the following heirs: Mary Poulin, Sellico Robidoux, Louis 
Robidoux, Eugenia Angel, and Celina (Cecile) Lapere. While these names do not altogether agree with those in the baptismal records at St. Louis, nor in the deed of partition filed after the death of Mrs. François Robidou, they do accord with records in St. Joseph. These show that Therese Eugenia Robidoux married John Angel, an Englishman, in St. Joseph in 1846; that Cecile, widow of Mr. McDowell, married Peter Le Pere in 1850; and Marie, as the Widow Brown, married Isadore Poulin in 1854; in each entry François Robidou is given as the father of the bride. The name Robidou is usually written with an $x$, due no doubt to the fact that both Joseph and François frequently gave a flourish to the final $u$ which somewhat resembled an $x$. The present generation spells it Robidoux.

\section{LOUIS BISSONET}

Louis Bissonet, dit Bijou, eldest son of Louis and Genevieve (Routier) Bissonet, was born in St. Louis, August 5, 1774. When twenty-five years old he was engaged by Auguste Chouteau to make a voyage to Mackinac, and he continued in his employ until the organization of the St. Louis Missouri Fur Company. He became one of the most trusted employees of that company and remained in its service for many years. In May, 1820 , he was in the employ of Pratte and Vasquez, and encamped on the Missouri River at a place "about one league below the old town of the Mahas nation." On May 22, 1820, the camp was suddenly attacked by a party of Indians, believed to have been the Sauks. Bissonet, Baptiste Ticio, and Charles Lemonde, dit La Malice, were severely wounded, and Louis Lecompte was killed. To save their lives, Pratte, Vasquez, and their surviving engages, leaving behind all their furs and peltries, horses and equipment, were forced to take flight to Council Bluffs, where the United States troops were stationed. In an affidavit made in St. Louis, July 6,1820 , and from which the above facts were ascertained, Bissonet stated that he had for a great number of years followed the Indian trade, and was well acquainted with the habits, manners, and customs of the Indians. In 1825, while in the employ of the French Fur Company, he was sent to accompany Gen. Atkinson and his party to treat with the Mandans. He was chief clerk and trader at Fort Clark in 1830; clerk of the Upper Missouri Outfit of the American Fur Company in 1831; chief trader of the French Company in 1833. 
Bijou Hills, South Dakota, close to the point where he had his trading-post, were named for him. There was a Bissonet in the Northwest Company, one with Parkman in 1846, and Joseph Bissonet, a brother of Louis, was an employee of the Missouri Fur Company in 1812-1813.

Louis Bissonet seems to have died in 1836 , as his brother-in-law, Paul Primeau, was appointed at St. Louis administrator of his estate January 2. 1837. His heirs were Joseph Bissonet, brother, living at that time in Mexico; Pelagie Primeau, his sister; Pierre and Elinore Ladouceur, his nephew and niece.

\section{CHARLES SANGUINET, Fils}

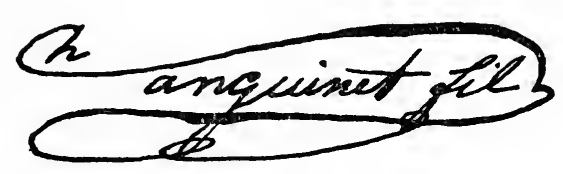

Charles SanguiNET, fils, was of a family prominent in Canada and in St. Louis. He was the son of Charles Sanguinet, who came to St. Louis from Quebec in the year 1775, and soon became prominent in its social and business life. The elder Charles was married to Marie Anne Conde, the eldest daughter of Dr. Auguste A. Conde, St. Louis' first physician; he became a member of the Spanish Company of explorers and traders, and later was associated with the various fur trading and commercial enterprises, in which he amassed a fortune. Charles and Marie (Condé) Sanguinet had three sons, Charles, Simon, and Christopher, all of whom had some experience in the mountains. Of them, Charles, known as "Sanguinet, fils," very closely followed his father's example in his business methods, and, while he had one or two reverses in business, managed to accumulate a fortune. When Sanguinet, fils, was thirteen years of age, he was sent to New Orleans to complete his education, after which he entered the grocery business. In 1808 he returned to St. Louis and immediately joined the Missouri Fur Company's expedition of that year. Sanguinet made three trips to the mountains. After his return from the last trip he engaged in the general mercantile business with his father, their store being in the lower part of the Sanguinet house on the northeast corner of Main and Elm Streets, and after the death of his father his 
brother-in-law, Captain Josiah Bright, joined with him. Their stock was said to be the largest in St. Louis, but in 1821 the partnership was dissolved. After a financial failure in $1827, \mathrm{Mr}$. Sanguinet moved to Franklin, Missouri, where he remained a year or two. He went to the Galena Mines to prospect for lead, in which venture he was very successful, and after four or five years returned to St. Louis, where he engaged in the real estate and banking business.

- Mr. Sanguinet was a very prudent, industrious, and studious man; of a kind and gentle disposition. His daughter, Mrs. Virginia Nadeau, aged ninety-two years (whose interest in things of to-day and clear recollections of the past made my visits to her a source of delight), gave this account of him: "My father was very Napoleonic and debonnaire. He always wore knee breeches, velvet coats, and lacey jabots. He was small in stature, with blue eyes and brown hair, and the most indulgent of fathers."

Mr. Sanguinet was married October 19, 1816, to Miss Cecile Brazeau, and their children, all of whom attained majority, were: Mary, Charles' Marshall, Amanda, Virginia, and Fanny; many of the descendants of whom are still living in Missouri and Texas. Mr. Sanguinet lived on his farm in St. Lonis County until about two weeks before his death, which occurred in the ciy of St. Louis, April 10, 1873, at the age of ninety-one years; the day of his birth being December 9, 1782. Some time before his death he divided all his property among his children.

\section{REUBEN LEWIS}

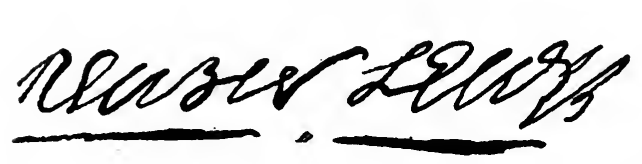

REUBEN LEWIS was born in A!bemarle County, Virginia, February 14, 1777. He came to Missouri in 1807 , with his brother, Meriwether Lewis. Soon afterwards he was appointed, by his brother, sub-agent of Indian Affairs, and as such signed a treaty with the Osages at Fort Osage, November 10, 1808. He became a partner in the St. Louis Missouri Fur Company and went up the Missouri River in 1809, where he remained in command of one of the forts until 1812 . After his return in 1813 , upon the rcommendation of General Clark, he was appointed 
Assistant Agent of Indian Affairs in Arkansas. In 1818 he was appointed Commissioner to run the survey line for the land given by the United States to the Cherokee Nation, in exchange for land ceded to the United States by the treaty of July 8, 1817; later he was appointed in the same sapacity, to lay off the Quapaw Reserve. He did not, however, serve on either Commission; the first, for the reason that the letter of instructions from the War Department miscarried and, in the meantime, the work was done by General Rector under directions from the general office; and the second, because of domestic troubles intervening, as will be seen from the following letter of $\mathrm{Mr}$. Harper. This letter, dated Albemarle County, Virginia, May 12, 1819, was addressed to Reuben Lewis, Agent for Cherokees on the Arkansas; and contained, among other things, the following:

"Our neigborhood has been severely afflicted for some months past, among which your mother's family have had a large share, owing to the Doctor's [probably his half-brother, Dr. John Marks] situation; which has become to appearances hopeless; his insanity has assumed a dangerous appearance so that it has been found necessary to confine him. * * * You will now consider yourself the only prop of the family. Your mother yesterday requested that you might be immediately informed $* * *$ and that you would hasten to their relief. Your mother's firmness is much weakened. Since writing above the Doctor has escaped from his friends and has not been heard of."

On August 15, 1819, Reuben Lewis wrote the Secretary of War: "From the peculiar and unfortunate situation of my mother and family, I must beg leave to decline accepting a commission to lay off the Quapaw Reserve, and for the same circumstances, I am compelled to resign my appointment as agent for the Cherokees on the Arkansas." His resignation was accepted, to take effect December 31, 1819, but before that date he returned to the family estate near Charlottesville, Virginia, and soon after took up the medical profession. In 1832 he married his cousin, Mildred Dabney. Reuben Lewis died in 1844, leaving no descendants.

\section{MAJOR JOHN DOUGHERTY}

John Dougherty was born near Bardstown, Nelson County, Kentucky, April 12, 1791, and died at Liberty, Clay County, Missouri, December 28, 1860. At the age of seventeen years he came to St. 
Louis and almost immediately engaged himself to the St. Louis Missouri Fur Company. He went with the first expedition of that company to the Upper Missouri, and after a few years' service in the capacity of trapper, trader, and clerk, he was appointed sub-agent under Major Benjamin O'Fallon, United States Indian Agent of the Upper Missouri tribes. On the resignation of Major O'Fallon in 1827, Major Dougherty was appointed United States Indian Agent. His headquarters were at Fort Leavenworth for the first ten years of his incumbency; at St. Louis for the years 1830-1833; then for a short time at Council Bluffs; and again at Fort Leavenworth, where he remained until 1839. When he resigned, the Missouri Republican of St. Louis, commenting on it, said editorially: "In losing the services of Major Dougherty the Government has lost a valuable public officer, one of the first for honesty, integrity, and worth in the land; the Indians a faithful and unflinching friend." Major Dougherty, as he wrote to his friend Senator Geyer, had spent forty-four years in the Western country from the Missouri to the Columbia, as trapper, Indian agent, and freighter. These were dangerous occupations, in which he became more perfectly acquainted with the habits, manners, tastes, and peculiarities of the Northwestern tribes than any man ever did before, or since, and no man has ever acquired such an influence over them. This influence did not result so much from his peculiar knowledge of them as it did from the nature of the man himself. He had a commanding and easy dignity, a bright and intellectual eye; an unvarying candor and directness in all his intercourse with them, which at once pleased, charmed, and overawed. His life with the Indians and uncouth men of the then uncivilized West did not take from him those inherent qualities of a gentleman. He was kind, courteous, and hospitable, a good neighbor, a warm and devoted friend, and an affectionate husband and father. Colonel D. C. Allen of Liberty, Missouri, pays this tribute to him: "Major Dougherty was a magnificent specimen of the frontiersman and Indian fighter, as well as that of the old-fashioned Missouri gentleman."

After Major Dougherty's resignation from the Indian Department he removed to Clay County, and was elected a representative to the Missouri Legislature of that county in the hard contest of 1840 . With Colonel Robert and William Campbell of St. Louis he was in the business of United States sutlers and freighters from about 1839 to 1855 .

He married at St. Louis, November I3, 1823, Mary, the daughter 
of Joseph Hertzog and Catherine Wilt. Four children were born to them: Lewis Bissell, who has the distinction of being the first white American born in what is now the State of Kansas and who served in the Confederate Army as captain in the Third Missouri Infantry, and is now living at Liberty, Missouri; Anne Elizabeth, who married General Charles Ruff, United States Army; O'Fallon, banker and stockraiser; John Kerr, who served in his brother's regiment in the Confederate Army, and was killed at the battle of Franklin, Tennessee. Mrs. Dougherty died in Philadelphia, March 27, 1873, aged seventy-four years.

\section{JEAN BAPTISTE POINT DU SABLE}

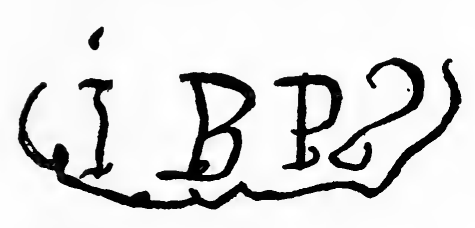

Jean Baptiste Point du SABLE, a French-WestIndian mulatto, reputed to be the first settler of Chicago; having had a tradinghouse and residence on the bank of the Chicago River, where Pine Street now ends,

prior to 1779. According to Mrs. John H. Kinzie, whose husband purchased the house built by Point du Sable, he was a native of San Domingo. N. Matson, in his French and Indian Wars of Illinois, says he was a runaway slave from Lexington, Kentucky. Point du Sable on June 14, 1809, in making an affidavit at St. Charles as to some Indian depredations on the Illinois River, designated himself "Baptiste Pointe Sable, a free mulatto man."

Point du Sable's chief occupation seems to have been that of a trader who wandered from place to place in the customary manner, and fortunately left a record now and then. In 1779 he was in Chicago, and in the summer of that same year he was established on the River Chemin, later known as Trail Creek, probably on the site of Michigan City, Indiana. It was at this place that he was arrested by Lieut. Bennett, who had been sent by Arent S. De Peyster of the British Army to forestall an anticipated attack on Mackinac by George Rogers Clark. Point du Sable's arrest seems to have been due to his seeming attachment to the American cause, although at the time he was in the employ of a British trader named Durand, who had under- 
taken to guide a British war party to the Illinois country to co-operate with Bennett. In his petition for a grant of land from the United States Government, presented in 1783 , Point du Sable satisfied the Commissioners that he was a citizen of the United States. He stated that as early as 1780 he had resided at Peoria with his family and had improved a farm of thirty acres between the Old Fort and the new settlements of Peoria. In 1790 he was again in Chicago and probably intermittently for five or six years. In this same year, on October 4, Susanne, the natural daughter of Point du Sable and an Indian woman, married Jean Baptiste Pelletier at Cahokia, and on October 7, 1799, a child born of this union was baptized in the Old Cathedral at St. Louis. The entry states that Pelletier's spouse, Susanne Point Sable, was "Habit a Chicagou." In 1796 he appeared at Mackinac. The next record of him is as a witness or juror on September 29, 1802, in the St. Clair County, Illinois (then Indiana Territory), Court of Common Pleas.

The first positive record I have found of Point du Sable's residence in Missouri is in 1805, when he purchased some land in St. Charles County from a negro named Rondin. The records show, from this time on until June, 1813 , several transfers of property in the city and county of St. Charles which were made jointly by Jean Baptiste Point Sable and "Baptiste Pointsable," as the names were usually written to distinguish father and son. i

In June, 1813 , as "Jean Baptiste Point de Sabre," he conveyed a lot and house in the city of St. Charles, together with all of his other property of various kinds, to Eulalia Barada, wife of Michael Derais. He was probably ill at the time, as the consideration mentioned was her promise to care for him in his illness and to bury him in the Catholic Cemetery at St. Charles. The names appearing on the records, "Point du Sable," "Point Sable," and "Point Sabre," are only variations of Point du Sable; the title to the property involved in each case being traceable to the same man. It is an interesting fact that Point du Sable always signed simply with his initials, "J. B. P. S.," as shown in the cut above.

The son, Baptiste Point du Sable, Jr., died sometime prior to February 17, 1814, as letters of administration were then granted at St. Charles, Missouri, on his estate to Henry Hight. No heirs were then given and no files in the case are to be found in the Probate Court. In July, 1814, Hight was removed and letters were granted to Jean Baptiste Pointsable, Sr., but there are no files in that case. In Sep- 
tember, 1814, "J. B. P. S., alias John B. Pointsable," applied to the court to take the benefit of the acts of the Territory concerning insolvent debtors, and to be released from imprisonment.

Whether it was the early Chicago settler, or the son, who was on this expedition, it is difficult to determine absolutely.

\section{AUGUSTE DUROCHER}

AUgUSTE DURocher was born about 1779, as the record of his marriage to Marie Louise Hortiz, widow of Joseph Laprise, solemnized in St. Louis, April 4, 1839, states that he was then about sixty years old. He had contracted an alliance with this lady many years previous. The church records of the St. Louis Cathedral show that there were born of this couple: Marie Claire, November 22, 182I, who married at St. Louis, January 7, 1839, Louis Dessaint of Quebec; Auguste Edmond, July 25, 1825; and Joseph, May 23, 1827. Marie Durocher, widow of Auguste, died December 30, 1863, leaving the fol. lowing heirs: Marie Dessaint, then living at Davenport, Iowa, daughter; Benjamin Durocher, son, living at Fort Benton; Louise Tetu, daughter; Julia, wife of Edmond Philibert, granddaughter; Augustus Schaeffer, grandson, children of her daughter Eloise.

On May 16, 1814, Joseph Philibert and his company started on an expedition to the Arapaho country, and Durocher accompanied him as interpreter. Upon the return of the Philibert party Durocher conducted a dancing school at Mr. Sanguinet's house and continued this profession for two years. On January 26, 1819 , he held his last ball, so the newspaper advertisement reads. He was next heard of as a tavern keeper on North Main Street in St. Louis in 1822. Growing tired of this monotonous life, he joined, in 1829, the Kansas Outfit of the American Fur Company, as a boatman. The next year he reengaged himself with the Company as boatman and hunter in the Upper Missouri Outfit and was stationed at Fort Union. He remained in this outfit until the fall of 1833 , when he returned to St. Louis. Durocher seems to have remained in St. Louis for about fifteen years, as the directories and church records indicate that he was there in 1839, 1845, and 1848. In $185 \mathrm{I}$ Mrs. Auguste Durocher is listed in the city directory as a widow. In about 1850 Auguste Durocher stopped in St. Joseph, Missouri, at the home of Pierre Harnois, who had been 
a gunsmith in the American Fur Company for many years. He asked Mr. Harnois to care for some papers which he was leaving until his brother, who closely resembled himself, should call for them. Mr. Durocher stated that he was going to the Sandwich Islands, and that he had previously been working in the mines of California. He was never heard from after that, nor is there any record of him in St. Louis after $\mathbf{1 8 4 8}$. He probably left St. Louis for the California gold-fields in 1849 .

\section{ANTOINE CITOLEUX, Dit LANGEVIN}

Antorne Citoleux, dit Langevin, is usually referred to as Citoleur, although sometimes as Sitoleur and Citolou. He was the son of Jean Baptiste and Rosalie (Pilon) Citoleux. On June 15, 1813, at St. Louis, he married Adrienne Trudeau, daughter of the schoolmaster Jean B. and Madeleine (Roy) Trudeau. His wife died August 24, 1813, aged seventeen years; the church record of the burial states that she was the wife of Antoine Sitoleur, a "traveller." After the return of this expedition, Citoleux remained in St. Louis for several years; at least, we have evidence that he was there from June, 1814, to 1816. He probably continued in the fur trade, although the only record we find of him in that connection is in October, 1823 , when he was in command of a Missouri Fur Company expedition, with which Jean Eymas and Joseph A. Sire went as voyageurs and hunters. While on his way from Fort Kiowa on the Missouri River to the Little Missouri, and in contemplation of a detour alone into dangerous country, Citoleux aecided to make his will. It was written by Sire in French, to which Citoleux signed his name by making his mark, and Sire and Eymas signed as witnesses. It was a very short document, and the only bequest was to his nephew and god-son, Antoine Louis Trudeau, son of his brother-in-law, Louis Trudeau. The estate consisted of a house and lot in St. Louis and two notes signed by Joseph Leblond and Joseph Roture, respectively. Neither of these notes could be collected, as Leblond died insolvent and Roture "had gone to the Spanish country." The will was lost for some time, and Sire and Eymas made affidavits concerning its contents. While the will, which was dated October 15, 1823, does not state the place at which it was made, Sire, in his affidavit, says it was done at the island called Simoneau. Eymas states that the next day after the publishing of the will by Cito- 
leux, and at a distance of about thirty miles below the Little Missouri, he and Citoleux parted, Citoleux to go to the Arikaras village on the Little Missouri, and Eymas and Sire to their destination; that he never saw Citoleux afterwards, but understood that he had been killed by the Arikaras soon after leaving him.

\section{LIST OF ENGAGES}

Taken from the Account Book, kept by Manuel Lisa himself, the original of which is in the Kansas State Historical Society, Topeka, Kansas.

la Compagny des Fourures du Missoury dans une Adventure Condutt par Manuel Lisa dans Deux Barge Partits l'Une Le 2 May et L'Autre le 6, 1812.

Reuben Lewis,

John C. Luttig,

Louis Lorimier,

Charles Sanguinet,

Michael E. Immel,

Juan Baptist Mayet,

Alexy Jollet,

François Roy,

Francois Laprise,

Pierre Lamonde,

Pierre Desseve,

Louis Lajoie,

Josef Lagasse, deserte,

Josef Leme,

Baptiste Pointsable,

Louis Manegre, deserte,

Andre St. Germain,

Pedro Antonio,

Josef Leclair,

Pierre Lange,

Antoine Labonté,

Pierre Larivier,

Guiomme Tardit,

Francois Lecompt,

Hipolite Papin,

Francois Guenville,

Bte. Latoulipe,
John Kenton,

Juan Baptist Lachapel,

Antoine Citoleur,

Antoine Mercier,

Ustache Carier,

Ant. \& Abraham Leroux [or

Ledoux],

Chevalier, Cadet,

Charles Latour,

William Brawn [Brown],

John Dokerty [Dougherty],

Caleb Grenwoods,

Brice Arnold,

William Weir,

Blan, Grand [A Pety (Petit) Blan was in the employ of the Company about this time],

Baptiste Provots,

Etienne Cadron, dit St. Pierre,

John Polly,

Antoine Peltier,

Antoine Canga,

Louis McKraken,

Edouard Rose,

Pierre Marasse,

Michel Rousseau,

Pierre Detalier, 
Augte. Bourbonnois, John Anderson, Bte. Alar,

Gabriel Agot,

L. T. Dejardin,

Daniel Larrison,

Paul Pereau,

Philip Fontaine,

Nicolas Glineau,

Josef Bissonet,

Louis Bissonet, dit Bijou,

Josef Joyal,

René Jussome [Jusseaume],

Pierre Primeau,

Gueniche St. Pierre,
Josef Garrot [Garreau],

Josef Bourrain,

Josef Elie,

Baptiste Ántoine, dit Machecou, Louis Archambeau,

Isaac Fouche,

Pierre Chaine,

François Oulle,

Toussain Charboneau,

James H. Audrin [Audrain],

Louis Delibac,

Morice Leduc,

Louis Chatelreau,

Alexander Toulouse,

Louis Norman,

George, negre.

Pour serche les Chasseures gui etet sur la Rre. des Espagnal et Arapaos7 Sept. 18 ז2.

M. Ch. Sanguinet.............\$350.

Cadet Chevalier.................. 300.

Ch. Latour. .................... 300 . 


\title{
BIBLIOGRAPHY.
}

\author{
MANUSCRIPTS, BOOKS, AND NEWSPAPERS CONSULTED \\ IN THE PREPARATION OF THIS VOLUME
}

\section{MANUSCRIPTS}

(Unless otherwise noted, these manuscripts are in the archives of the Missouri Historical Society.)

Ashley, William H. Letters and accounts, 1811-1836.

Atrinson, General Henry. Journals of 1825 and 1828 .

Bates, Frederick (Secretary of Missouri Territory and afterwards Governor of the State). Personal and official letters, appointments, and documents, $1807-1825$.

Biddle, Major Thomas. Observations on the Missouri River, 1819.

Crensus of Districts of St. Louis, Ste. Genevieve, St. Charles, Carondelet, Florissant, Merrimeca to Platin, New Bourbon, and Marais des Liards, 1787,1791 , and 1796.

Chouteau, Auguste. Collection of business and family papers, letters, notes, and accounts of the fur trade.

Chouteau, Pierre. Important collection of papers relating to the fur trade on the Upper Missouri and including the following journals and letter-books: Journal des Cahos, August, 1778-December, 1781; Letter-books, March, 1798-January, 1817; September, 1817-June, 1819; October, 1804-April, 1819; Journals of Fort Tecumseh, January, 1830-April, 1831; January-June, 1832; Letterbooks of Fort Tecumseh, November, 1830-December, 1835; Fort Pierre, December, 1832-August, 1835; June, 1845-June, 1846; December, 1847-May, 1848; February, 1849-December, 1850. Fort Union, October, 1833-December, 1835 .

Church Registers (copies of the originals being in the Missouri Historical Society):

Arkansas Post,

Cahokia,

Carondelet,

Florissant,

Fort Chartres,

Kaskaskia,

New Madrid,

Old Mines,

Osage Indian Mission,

Portage des Sioux,

St. Charles,

Ste. Genevieve,

St. Louis,

St. Mary's, Kansas,

Village de Saint Philippe,

Vincennes Post.

Clamorgan, Jacques. Collection, 1794-1817. 
Clark, William. Memorandum-book, September, 1820, to May, 1825; also letters and reports.

Crooks, Ramsey. Letters of Ramsey Crooks, John J. Astor, and American Fur Company, 1813-1846. Transcript made through the courtesy of Mr. C. M. Burton.

Dalton, Mary L., Collection. A few letters and documents, i812I819.

DARBY, John F. Correspondence, personal and official, 1826-r888.

Dougherty, Major John (Indian Agent for Upper Missouri tribes). Letters, receipts, notes, and reports, $1834-1856$.

Drips, ANDrew (Indian Agent and trader). Correspondence and accounts $1832-1860$.

Farrar, Dr. Bernard G. Account-books from $1807-1836$, containing names of nearly all of the early residents of St. Louis.

Forsyth, Thomas. Collection of letters and reports while Indian Agent, 1811-1822.

Hertzog, Joseph (Merchant at Philadelphia). Letters to Christian Wilt and others, $1811-1813$.

Hunt, Theodore (Recorder of Land Titles). Hunt's minutes; the testimony relating to lands in the towns and villages of St. Louis, St. Charles, St. Ferdinand, Portage des Sioux, Carondelet, New Madrid, New Bourbon, Ste. Genevieve, Villa a Robert, Missouri, and Village of Arkansas. Taken February I3 to May 25, 1825.

Kearny, General Stephen W. Journals of, for 1820, 1824, 1825 , I846-1847.

Kennedy, Alexander. Journal kept at Fort Clark, 1833-1834.

Kennerly, James. Memorandum-book for 1824-1825 at Council Bluffs; same for 1839-1840 at St. Louis.

Lisa, Manuel. Collection of letters, contracts, deeds, accounts, and litigations, 1794-1820.

Maffitt, Pierre Chouteau. Collection of documents relating to the fur trade and Indians of the Upper Missouri and the Southwest, $1807-1855$; lists of men in the employ of P. Chouteau \& Co., 1807-1850; of American Fur Co., 1828-1849.

Maher, Joseph. Collection of Captain James Callaway's letters, diary, and muster-rolls, War of 1812 .

Missouri County Tax Lists. I815-1842.

Missouri Fur Company. Book containing the Articles of Association, dated January 24,1812 , and minutes of the Board meetings from January 27,1812 , to January 17,1814 . The original of this is in the library of the Kansas State Historical Society, Topeka, Kansas.

Post, Mrs. E. G. Memorandum-books, I812-1871, containing numerous references to Colonel Eli B. Clemson.

St. Charles Archives. French and Spanish records, deeds, conces- 
sions, marriage contracts, etc., 1790-1806. Circuit Court, Probate Court, and Recorder of Deeds records, 1806-1830.

St. Clair County. Minutes of the County Court of Common Pleas, held at Cahokia, December Term, I801-June Term, I805.

Ste. Genevieve Archives. Marriage contracts, deeds, concessions, Circuit and Probate Court records, 176I-1854.

ST. Lours Archives, and various Court records, 1764-i 870.

Sibley, Mator George C. (Indian Agent). Letters, diaries, reports, personal and official, $1805^{-1850}$.

St. Louis Mrssouri Fur Company. Account-books, containing also letters, articles of association and minutes of meetings, March, 1809-January, 1812.

Sublette Collecton. Comprising the papers of William, Milton, and Andrew Sublette; business correspondence of Smith, Jackson and Sublette, and Rocky Mountain Fur Co., 1826-1857.

Tesson, Robert. Collection of letters, accounts, etc., on fur trade and Indian affairs, $1806-1838$.

U. S. Superintendent of Indian Afrairs. Correspondence of William Clark and others at St. Louis from $1813-1855$, twenty-nine volumes. In the library of the Kansas State Historical Society. Indian Office, Washington, D. C. Letters, reports, accounts, and various documents covering the period from 1811 to 1848 .

Valle, Captain Francois. Collection, 1796-1846.

Vasque7, Louis and Benito. Personal and business correspondence, 1804-1851.

Waldo, DR. David. Journals and other papers relating to the Santa Fe trade, 1832-I864.

Waldo, Wrlliam. Recollections of a Septuagenarian. Printed in part in Vol. I, No. 2, of the Missouri Historical Society Collections.

Washington County, Missouri. Court papers, 1815-1846.

Wirt, Christian. Letters written at St. Louis to his uncle Joseph Hertzog of Philadelphia, John C. Luttig, and others, from July, 1812, to September, 1815. An important collection of letters containing valuable material on the social and commercial life in St. Louis and the War of 1812 .

\section{BOOKS AND PERIODICALS}

Abney, A. H. Life and Adventures of L. D. Lafferty. New York, 1875 .

American State Papers. Claims, Washington, 1834.

Foreign Relations. Vol 4. Washington, 1834.

Indian Affairs. 2 vols. Washington, 1832.

Public Lands. 8 vols. Washington, 1832 .

Arransas Historical Association. Publications. Fayetteville, 1906I9II. 
Armstrong, B. G. Early Life Among the Indians. Ashland, r892. Armstrong, M. K. Early Empire Builders of the Great West. St. Paul, r9or.

Audubon, Maria R.. Audubon and His Journals, with zoological and other notes by Elliott Coues. 2 vols. London, 1898.

Babcock, Rufus, Editor. Forty Years of Pioneer Life. Memoir of John Mason Peck, edited from his journals and correspondence. Philadelphia, 1864 .

Ballantyne, R. M. Away in the Wilderness; or Life Among the Indians and Fur Traders of North America. Philadelphia, 1869.

Barrows, William. The General; or Twelve Nights in the Hunters' Camp. Boston, 1870.

BEck, L. C. Gazetteer of the States of Illinois and Missouri. Albany, 1823 .

Beckwourth, J. P. Life and Adventures of James P. Beckwourth. New York, 1856.

Belden, George P. Belden, the White Chief; or Twelve Years Among the Wild Indians of the Plains. Cincinnati, 1875 .

Bell, Ovid. Short History of Callaway County, Mo. Fulton, 1913. Bell, W. S. Old Fort Benton. Helena, 1909.

Brlzon, F. L. Annals of St. Louis in Its Early Days Under the French and Spanish Dominations. St. Louis, I880.

Annals of St. Louis in Its Territorial Days: St. Louis, 1888.

Brographical Cyclopedia of Representative Men of Maryland and the District of Columbia. Baltimore, 1879 .

Brographical and Historical Memotrs of Eastern Arkansas. Chicago, 1890.

Bledsoe, A. J. Indian Wars of the Northwest. San Francisco, 1885 .

Boller, H. A. Among the Indians; Eight Years in the Far West. Philadelphia, 1868.

Boyle, Esmeralda. Biographical Sketches of Distinguished Marylanders. Baltimore, 1877 .

Brackenridge, H. M. Recollections of Persons and Places in the West. Philadelphia, 1834 .

Views of Louisiana, together with a Journal of a Voyage $U_{p}$ the Missouri River in 1811. Pittsburgh. 1814.

Bradbury, John. Travels in the Interior of America in the Years 1809, 1810, and 1811. London, 1819.

Brower, J. V. Memoirs of Explorations in the Basin of the Mississippi. Mandans, Vol. 8. St. Paul, 1904.

Brumbaugh, G. M. Maryland Records, Colonial, Revolutionary, County, and Church, from Original Sources. Baltimore, 1915.

Bryant, Edwin. What I Saw in California; being a journal of a tour in the years 1846,1847 . New York, 1848 . 
Bryce, George. Remarkable History of Hudson's Bay Company including that of the French traders of Northwestern Canada and of the North West, XY, and Astor Fur Companies. New York, rgro.

Bryan, W. S., and Robert Rose. History of the Pioneer Families of Missouri. St. Louis, I876.

Burnetr, P. H. Recollections and Opinions of an Old Pioneer. New York, 1880.

Burton, C. M. Cadillac's Village. Detroit, r896.

Burton Historical Collections. Manuscripts from the Burton Collections, edited by Miss M. Agnes Burton. Detroit, 1916-19r8.

Carstarphen, J. E. My Trip to California in '49. Louisiana, Mo., I9I4.

Carvalho, S. N. Incidents of Travel and Adventure in the Far West with Colonel Fremont's Last Expedition. New York, 1857.

Catrin, George. Letters and Notes on the Manners, Customs, and Condition of the North American Indians. 2 vols. London, 1841.

Chandler, Katherine. Bird-Woman of the Lewis and Clark Expedition. New York, 1905.

Chappell, P. E. History of the Missouri River. 1905.

Chicago Historical Society. Collections, r882-rgo8.

Chitrenden, H. M. American Fur Trade of the Far West. 3 vols. New York, 1902.

History of Early Steamboat Navigation on the Missouri River. 2 vols. New York, 1903.

Chittenden, H. M., and Alfred T. Richardson. Life, Letters, and Travels of Father Pierre Jean De Smet, 180r-1873. 4 vols. New York, 1905 .

Clark, W. P. Indian Sign Language. Philadelphia, 1885.

Cochran, Joseph. History of Mifflin County, Pennsylvania. Harrisburg, 1879.

Collet, O. W. General Index to the Archives in the Office of the Recorder of Deeds for the County of St. Louis. 6 vols. St Louis, 1876.

Conard, H. L. "Uncle Dick Wootton," the Pioneer Frontiersman of the Rocky Mountain Region. Chicago, roro.

Cone, W. W. Historical Sketch of Shawnee County, Kansas. Topeka, 1877 .

Cooke, P. St. G. Scenes and Adventures in the Army. Philadelphia, 1857 .

Coues, Elliotr. Expeditions of Zebulon M. Pike. 4 vols. New York, 1895 .

History of the Expedition Under the Command of Captains. Lewis and Clark. 4 vols. New York, 1893.

New Light on the Great Northwest: The Henry-Thompson Journals. 3 vols. New York, 1897. 
Cox, Ross. Adventures on the Columbia River. New York, 1832 .

Coyner, D. H. The Lost Trappers. Cincinnati, 1859 .

Crawford, Medorem. Journal of. In Sources of the History of Oregon. Eugene, 1897.

Culbertson, T. A. Journal of an Expedition to the Mauvaises Terres and Upper Missouri in 1850 . In Documents Printed by Order of the Senate of the United States. Washington, 1851 .

Cumings, Samuel. Western Pilot. Cincinnati, 1833.

Dale, H. C. Ashley-Smith Explorations and the Discovery of a Central Route to the Pacific, 1822-1829. Cleveland, 1918.

Davidson, G. C. The North West Company. Berkeley, 1918.

De Barthe, Joseph. Life and Adventures of Frank Grouard. St. Joseph, 1894 .

De Smet, Rev. P. J. Letters and Sketches; with a Narrative of a Year's Residence Among the Indian Tribes of the Rocky Mountains. Philadelphia, 1843.

Oregon Missions and Travels Over the Rocky. Mountains in 1845, 1846. New York, 1847 .

Delano, A. Life on the Plains and Among the Diggings; being scenes and adventures of an overland journey to California. Auburn, 1854 .

Dellenbaugh, F. S. Breaking the Wilderness. New York, 1905. Fremont and '49. New York, 1914.

Dodge, R. I. Our Wild Indians. Hartford, 1885.

Douglas, W. B. Manuel Lisa. In Missouri Historical Society Collections. Vol. 3. St. Louis, r9r1.

Drake, G. Biography and History of the Indians of North America . Boston, 1857 .

Drannan, W. F. Thirty-one Years on the Plains and in the Mountains. Chicago, 1906.

Dugas, L'Abвe G. Un Voyageur des Pays d'en Haut. Jean B. Charbonneau. Montreal, 1890.

Dunbar, Rev. John. Journal of Mr. Dunbar's Mission to the Pawnees. In Missionary Herald, Vol. 31. Cincinnati, 1835.

Dye, Mrs. Eva E. The Conquest. Chicago, 1902.

Early Settlers' Association of Dubuque. Biography of Thomas McKnight. Dubuque, 1866.

Eastman, Mrs. Mary. Dahcotah, or Life and Legends of the Sioux. New York, 1849.

Edmunds, A. C. Pen Sketches of Nebraskans. Lincoln, 187r.

Edwards, R., ANd M. Hopewell. Edwards' Great West. St. Louis; 1860.

Egle, Wrlliam H. Pennsylvania Genealogies. Harrisburg, 1886.

Elliotr, R. S. Notes Taken in Sixty Years. St. Louis, I883. 
Ellis, Franklin. History of Lancaster County, Pennsylvania. Philadelphia, 1883 .

EMORY, W. H. Notes of a Military Reconnoissance from Fort Leavenworth to San Diego, California. Washington, 1848 .

Farnham, T. J. Life, Adventures, and Travels in California. New York, 1850.

Travels in the Great Western Prairie. New York, 1843.

Fletcher, Alice C. Historical Sketch of the Omaha Tribe of Indians in Nebraska. Washington, 1885 .

Flint, Timothy. Recollections of the Last Ten Years Passed in Occasional Journeying in the Valley of the Mississippi. Boston, 1826.

Fowre, Gerard. Antiquities of Central and Southeastern Missouri. Washington, 1910. (Smithsonian Institution, Bureau of American Ethnology, Bulletin 37.)

Fowler, JacoB. Journal of Jacob Fowler. Edited by Elliott Coues. New York, 1898.

Franchere, Gabriel. Narrative of a Voyage to the Northwest Coast of America. Redfield, 1854 .

Fremont, J. C. Narrative of the Exploring Expedition to the Rocky Mountains in 1842, and to Oregon and North California, 1843-1844. New York, 1846.

Report of the Exploring Expedition to the Rocky Mountains. Washington, 1845 .

Gallatin, Albert. Synopsis of the Indian Tribes within the United States. In American Antiquarian Society Transactions, Yel. 2. Cambridge, 1836 .

Gass, Patrick. Journal of the Lewis and Clark Expedition. Philadelphia, 1810.

Gray, P. L. Gray's Doniphan County, Kansas, History. Bendena, 1905 .

Greenhow, Robert. History of Oregon and California. Boston, 1845 .

Gregg, Josiah. Commerce of the Prairies. 2 vols. New York, 1845.

Grinnell, G. B. Beyond the Old Frontier. New York, 1913.

The Fighting Cheyennes. New York, 1915.

Gue, B. F. History of Iowa, from the Earliest Times to the Beginning of the Twentieth Century. 4 vols. New York, 1903.

Haines, E. M. American Indian. Chicago, 1880.

Hall, James. Letters from the West; containing sketches of scenery, manners, and customs. London, 1828 .

Hallum, John. Biographical and Pictorial History of Arkansas. Albany, 1887.

Hamilton, W. T. My Sixty Years on the Plains. New York, 1905.

Hans, F. M. Great Sioux Nation. Chicago, 1907.

Hanson, J. M. Conquest of the Missouri. Chicago, 1909. 
Harmon, D. W. Journal of Voyages and Travels in the Interior of North America. New York, rgo3.

Harris, W. R. Catholic Church in Utah. Salt Lake, I909.

Heap, G. H. Central Route to the Pacific from the Valley of the Mississippi to California. Philadelphia, 1854.

Hebard, Dr. Grace R. Pathfinders from River to Ocean. Chicago, 1912.

Pilot of First White Men to Cross the American Continent. In Connecticut Magazine (Hartford, 1907), Vol. 3, p. 459; and Journal of American History, Vol. I, p. 467.

Hempstead, Fay. Pictorial History of Arkansas. St. Louis, 1890.

Henry, Alexander, and David Thompson. New Light on the Early History of the Greater Northwest; the manuscript journals of Alexander Henry and David Thompson, 1799-1814. Edited by Elliott Coues. 3 Vols. New York, 1897.

Hewitr, R. H. Across the Plains and Over the Divide. New York, 1906.

Hrldreth, James. Dragoon Campaigns to the Rocky Mountains; being a history of the regiment of U.S. Dragoons. New York, 1836.

Historre de la Tribu des Osages. Paris, 1827.

Historical Encyclopedia of Illinors and History of St. Clair County. 2 Vols. Chicago, 1907.

Historical Society of Pennsylvania. Collections. Philadelphia; 1853.

Pennsylvania Magazine of History and Biography. Philadelphia, 1877-1920.

Memoirs. Philadelphia, 1826-1895.

Hrstorical Socrety of Western Pennsylvania. Western Pennsylvania Historical Magazine. Pittsburgh, 1918-1920.

History of Frankin, Jefferson, Washington, Crawford, and Gasconade Counties, Mrssouri. Chicago, 1888.

History of Howard and Chariton Counties, Missourr. St. Louis, 1883.

History of Marion County, Mrssouri. St. Louis, 1884 .

History of Pottawattamie County, Iowa. Chicago, 1883.

History of St. Charles, Montgomery, and Warren Counties, Missouri. St. Louis, 1885 .

Hrstory of Southeast Missouri; embracing an historical account of the Counties of Ste. Genevieve, St. François, Perry, Cape Girardeau, Bollinger, Madison, New Madrid, Pemiscot, Dunklin, Scott, Mississippi, Stoddard, Butler, Wayne, and Iron. Chicago, 1888.

History of the State of Nebraska. Chicago, 1882

Hrstory of Vernon County, Missouri. St. Louis, 1887.

Hobbs, Captain James. Wild Life in the Far West. Hartford, r873. 
HodGe, F. W. Handbook of American Indians. 2 vols. Washington, 1907. (Smithsonian Institution, Bulletin 30.)

Holley, Franc:s C. Once Their Home; or Our Legacy from the Dakotahs. Chicago, 1890.

Holmes, Captain Reuben. Five Scalps; a mountain story. St. Louis Reveille, July 17 th and 24th, 1848. (T ie story of Edward Rose, with several references to Toussaint Charbonneau.)

HoRn, H. B. Horn's Overland Guide. New York, 1852.

Houck, Louis. History of Missouri. 3 vols. Chicago, 1908.

Memorial Sketches of Pioneers and Early Residents of Southeast Missouri. Cape Girardeau, 1915.

Spanish Régime in Missouri. Chicago, 1909.

Houghton, Eliza P. D. The Expedition of the Donner Party. Chicago, IgII.

Hubbard, G. S. Incidents and Events in the Life of Gurdon S. Hubbard. Chicago, 1888.

Hunter, John. Memoir of a Captivity Among the Indians of North America. London, 1824.

Illinors Catholic Historical Society. Review. Chicago, I9121920.

Illinois State Historical Library. Collections. Springfield, 19031915.

Publications. Springfield, 190I-1907.

Transactions. Springfield, I908-I918.

Illinors State Historical Society. Journal. Springfield, 1908-19i8.

Iowa Historical Department. Annals. Des Moines, i863-igir.

Iowa State Historical Society. Iowa Historical Record. Iowa City, 1887-1892.

Jowa Journal of History and Biography. Iowa City, 1903-1920.

InMan, HenRy, and W. F. Cody. Great Salt Lake Trail. Topekas 1899.

Irving, Washington. Astoria. 2 vols. Phila:elphia, 1841. Rocky Mountains Sketches. 2 vols. Philadelphia, 1832. Tour of the Prairies. Philadelphia, I835.

James, Edwin. An Account of an Expedition from Pittsburgh to the Rocky Mountains, Performed in the Years 1817 and 1820, Under. the Command of Major Stephen Long. 2 vols. Philadelphia, 1823

James, Thomas. Three Years Among the Indians and Mexicanse Waterloo, 1846. Reprinted, and edited by Walter B. Douglas. St. Louis, 1917.

Johnson, Harrison. Johnson's History of Nebraska. Omaha, I880. JORDAN, J. W. Colonial and Revolutionary Families of Pennsylvania. 3 vols. New Yosk, 191 I.

Kansas State Historical Society. Collections. Topeka, i875-1918. Biennial Reports. Topeka, I892-I9r2. 
Kertr, C. P. Chronicles of Pennsylvania. 2 vols. Philadelphia, 1917.

Keluy, Fanny. Narrative of My Captivity Among the Sioux. Cincinnati, $187 \mathrm{I}$.

Kel.y, William. L'Emigration par Terre en Californie. Voyage du Fort Independence sur le Missouri aux Lavages d'Or de la Californie en traversant les Montagnes Rocheuses. 1849.

Kinzir, Mrs. J. A. Wau-bun, the "Early Day" in the Northwest. New York, 1856.

Lang, J. D., and Samuer Tayzor. Report of a Visit to Some of the Tribes of Indians Located West of the Mississippi River. New York, 1843 .

Langworthy, Franklin. Scenery of Plains, Mountains, and Mines; or A Diary Kept upon the Overland Route to California. Ogdensburgh, 1855 .

Laroceue, Antorne. Journal of Larocque, from the Assiniboine to the Yellowstone, 1805. Edited with notes by L. J. Burpee. Ottawa, 19ro. (Publications of Canadian Archives, No. 3.)

Larpenteur, Charles. Forty Years a Fur Trader on the Upper Missouri. Edited by Elliott Coues. 2 vols. New York, 1898.

Latrobe, C. J. A Rambler in North America. 2 vols. London, 1835.

Iaut, Agnes C. Conquest of the Great Northwest. 2 vols. New York, 1908.

Pathfinders of the West. New York, 1907.

Leonard, Zenas. Adventures of Zenas Leonard, Fur Trader and Trapper, 1831-1836. Edited by Dr. W. T. Wagner. Cleveland, 1904.

Levens, H. C. History of Cooper County, Missouri. St. Louis, 1876 .

Lewis, Meriwether. Original Journals of the Lewis and Clark Expedition, 1804-1806. Edited by Reuben Gold Thwaites. 8 vols. New York, 1904.

Loughborough, J. History of American Fur Trade. In Western Journal and Civilian. St. Louis, 1849.

McClung, John. Sketches of Western Adventure. Louisville, 1879.

McKenney, T. L. History of the Indian Tribes of North America. 4 vols. Philadelphia, 1872.

Mackenzie, Alexander. Voyages from Montreal on the River St. Lawrence Through tie Continent of North America, with a Preliminary Account of the Rise, Progress, and Present State of the Fur Trade. London, ISOI.

Magazine of Western History. 12 vols. Cleveland, 1884-1890-

Maguire, A. J. The Indian Girl Who Led Them (Sacajawea). Portland, 1905 .

Maryland Calendar of Wirls. Compiled and edited by Jane Baldwin. 5 vols. Baltimore, 1901-1917. 
Maryland Historical Society. Archives. Baltimore, 1883-1919. Magazine. Baltimore, igo6-1920.

Publications. Baltimore, 1844-1880.

Masson, L. R. Les Bourgeois de la Compagnie du Nord-Ouest. Quebec, 1889.

Matthews, Washington. Ethnology and Philology of the Hidatsa Indians. Washington, 1877 .

Maximilian, Prince of Wred. Travels in the Interior of North America. London, 1843 .

Minnesota Historical Society. Collections. St. Paul, 1850-1914.

Missouri Historical Society. Collections. St. Louis, 1875-1913.

Möllhausen, Baldwin. Diary of a Journey from the Mississippi to the Coasts of the Pacific. Translated by Mrs. Percy Sinnett. 2 vols. London, 1858 .

Moffetre, J. F. Territories of Kansas and Nebraska. New York, 1856.

Montana Historical Society. Contributions to the Historical Society of Montana. Helena, 1876-1917.

Monthly Historian. Devoted to history, art, science, current events, etc. Published by A. L. van Osdel. Mission Hill, S. D., 1912-1913.

Mooso, Josiah. Life and Travels of Josiah Mooso. Winfield, r888.

Morice, A. G. Dictionnaire Historique des Canadiens et des Metis Française de l'Ouest. Kamloops, 1918.

Morse, Jedediar. Report to the Secretary of War of the United States on Indian Affairs. New Haven, 1822.

Murray, C. A. Travels in North America. 2 vols. London, 1839.

Nead, D. W. Pennsylvania-German in the Settlement of Maryland. Lancaster, I9I4.

Nebraska State Historical Society. Transactions, Reports, Collections, and Publications. Lincoln, 1885-1917.

Neihardt, J. G. Story of Hugh Glass. New York, I9r 5.

Nerl., E. D. Dahkotah Land and Dahkotah Life, with the History of the Fur Traders of the Extreme Northwest During the French and British Dominion. Philadelphia, 1859.

Nicollet, I. N. Report Intended to Illustrate a Map of the Hydrographical Basin of the Upper Mississippi River. Washington, 1843 .

Niles Register. Baltimore, I812-1818.

North Dakota State Historical Society. Collections. Bismarck, I906-1913.

Notes and Queries, Historical, Biographical, and Genealogical, Relating Chiefly to the Interior of Pennsylvania. Edited by W. H. Egle. Harrisburg, 1894-1901.

Nutrall, Thomas. Journal of Travel into the Arkansas Territory, 1819. Philadelphia, 1831 . 
Oenler, G. F., and Davis Z. Smith. Description of a Journey and Visit to the Pawnee Indians Who Lived on the Platte River, a Tributary of the Missouri, April 22-May 18, 1851. Reprinted from Moravian Church Miscellany, 1851-1852. New York, 1914.

Old Settlers' History of Bates County, Missouri. Amsterdam, Missouri, 1897.

Ontario Historical Society. Papers and Records. Montreal, 18991914.

Oregon Historical Society. Quarterly. Portland, I90I-19I9.

Oregon Pioneer Association. Transactions. Salem, 1873-1897.

Pallanino, L. B. Indian and White in the Northwest. Baltimore, I894.

Palliser, John. A Solitary Hunter; or Sporting Adventures in the Prairies. London, 1856 .

Parker, Samuel. Journal of an Exploring Tour Beyond the Rocky Mountains. Ithaca, 1842 .

Parkman, Francis. Oregon Trail. Boston, 1882.

Patrie, J. O. Personal Narrative of James O. Pattie of Kentucky • Edited by Timothy Flint. Cincinnati, 183 I.

Pearce, Stewart. Annals of Luzerne County, Pennsylvania. Philadelphia, 1866.

Pennsylvania Archives. Philadelphia, r852-19r4.

Pennsylvania Colonial Records. Harrisburg, 1838-1853.

Pennsylvania-German Magazine. Lebanon, I900-igil.

Perkins, J. H. Annals of the West. Cincinnati, 1847.

Pixe, Albert. Prose, Sketches and Poems Written in the Western Country. Boston, 1834 .

Pixe, Major Z. M. Account of Expeditions to Sources of the Mississippi and Through Western Parts of Louisiana to the Sources of the Arkansaw, Kans, La Platte, and Pierre Jaun Rivers. Philadelphia, 1810.

Pioneer and Historical Society of Michigan. Historical Collections. Lansing, 1874-1912.

Pope, W. F. Early Days in Arkansas. Little Rock, 1895.

Poole, Captain D. C. Among the Sioux of Dakota. New York, 1881.

Qualfe, M. M. Chicago and the Old Northwest. Chicago, 1913.

Quarfe, M. M., Editor. Journals of Captain Meriwether Lewis and Sergeant John Ordway. Madison, I916.

Richardson, R. L. Amos Richardson of Boston and Stonington, with a Contribution to the History of His Descendants. New York, I906.

Riggs, S. R. Dakota Portraits. In Minnesota History Bulletin, Vol. 2, No. 8. St. Paul, 1918.

Mary and I. Forty Years with the Sioux. Boston, 1880. 
Tah-koo Wah-kan; or The Gospel Among the Dakotas. Boston, 1869.

Roberts, T. P. Report of a Reconnaissance of the Missouri River in 1872. Washington, 1875 .

Robinson, H. M. Great Fur Land, or Sketches of Life in the Hudson's Bay Territory. New York, 1879.

Root, F. A., ANd W. E. Connelley. Overland Stage to California. Topeka, I90I.

Rosen, Rev. Peter. Pa-ha-sa-pah; or The Black Hills of South Dakota. St. Louis, 1895.

Ross, Alexander. Adventures of the First Settlers on the Oregon or Columbia River. London, 1849. Fur Hunters of the Far West. London, 1855.

Rotuert, Otro. History of Muhlenberg County, Kentucky. Louisville, I913.

Royce, C. C. John Bidwell, Pioneer, Statesman, and Philanthropist; a biographical sketch. Chico, California, 1906.

Rupp, I. D. Collection of Upwards of Thirty Thousand Names of German, Swiss, Dütch, and French, and Other Immigrants in Pennsylvania from $1727-1776$. Philadelphia, 1875 .

Russell, Osborne. Journal of a Trapper, 1834-1843. Boise, 1914.

Rutr, C. L. Daily News History of Buchanan County and St. Joseph, Missouri. St. Joseph, 1898.

Ruxton, G. F. Adventures in Mexico and the Rocky Mountains. New York, 1848.

Life in the Far West. Edinburgh, 1851.

SABIN, E. L. Kit Carson Days. Chicago, I914.

SAGE, R. B. Rocky Mountain Life. Boston, 1857 .

St. Louis Directories, I82I-I860.

Saxe-Wermar-Ersenach, Bernard, Duke of. Travels Through North America During the Years 1825 and 1826. 2 vols. Philadelphia, 1828.

Scharf, J. T. Chronicles of Baltimore. Baltimore, 1874. History of Maryland. 3 vols. Baltimore, 1879. History of St. Louis City and County. 2 vols. Philadelphia, 1883.

Schoolcraft, H. R. Journal of a Tour into the Interior of Missouri and Arkansas. London, $182 \mathrm{I}$.

Schoonover, T. J. Life and Times of General John A. Sutter. Sacramento, 1895 .

Scrultz, J. W. The Bird-Woman (Sacajawea), Guide of Lewis and Clark. Boston, 1918.

Scotr, L. T. Sacajawea, the Unsung Heroine of Montana. Armstead, I915. 
Shambaugh, B. F., Editor. First Census of the Original Counties of Dubuque and Demoine, Iowa, Taken in 1836 . Des Moines, 1898 .

Sherdon, Rev. Stewart. Gleanings by the Way, from 1836-1889. Topeka, 1890.

ShePARd, E. H. Early History of St. I.ouis. St. Louis, 1870.

Shinn, J. H. Pioneers and Makers of Arkansas. Little Rock, 1908.

Skinner, C. L. Adventurers of Oregon. New Haven, 1919. (Chronicles of American History, Vol. 22.)

Snelling, W. J. Tales of Travels West of the Mississippi. Boston, 1830.

Soutr Dakota Historical Society. Collections. Aberdeen and Pierre, 1902-1918.

Stewart, Sir William D. Altowan; or Incidents of Life and Adventure in the Rocky Mountains. 2 vols. New York, 1846. Edward Warren. London, 1854 .

Stipes, M. F. Fort Orleans. Jamesport, 1906.

Stockard, S. M. History of Lawrence, Jackson, Independence, and Stone Counties, Arkansas. Little Rock, 1904.

Sulte, Benjamin. Histoire des Canadiens-Français, 1608-r880. 8 vols. Montreal, 1884 .

Tallent, Annie D. The Black Hills; or The Last' Hunting-Ground of the Dakotahs. St. Louis, 1899 .

Tanguay, L'Abbe Cyprien. Dictionnaire Genealogique des Familles Canadiennes. 7 vols. Quebec, 1871 .

A Travers les Registres, Notes Recueilles. Montreal, 1886.

Tasse, Joseph. Les Canadiens de l'Ouest. Montreal, 1878 .

TAyroR, J. H. Sketches of Frontier and Indian Life on the Upper Missouri and Great Plains. Bismarck, 1897 .

Kaleidoscopic Lives; a companion book to Frontier and Indian Life. Washburn, 1902.

Thomas, W. L. History of St. Iouis County, Missouri. 2 vols. St. Louis, Igrx.

Tuwaites, R. G., Editor. Early Western Travels, 1748-1846. 32 vols. Cleveland, 1904-1906.

TICE, J. H. Over the Plains and On the Mountains; or Kansas, Colorado, and the Rocky Mountains. St. Louis, 1872.

Townsend, J. K. Narrative of a Journey Across the Rocky Mountains to the Columbia River. Philadelphia, 1839.

Treaties Between the United States of America and the Severa $\mathrm{l}$ INDIAN TRIBES FROM $177^{8}$ To 1837 . Washington, 1837 .

Trudeau, J. B. Journal. Part $X$ in American Historical Review, Vol. 19; Part 2 (translation) in Missouri Historical Society Collections, Vol. 4. 
Twrtchell, R. E. Leading Facts of New Mexican History. 2 vols. Cedar Rapids, I9II.

Spanish Archives. 2 vols. Cedar Rapids, 1914.

Trler, Daniel. Concise History of the Mormon Battalion. Salt Lake City, I88I.

Udell, John. Incidents of Travel to California Across the Great Plains. Jefferson, 1856.

United States Bureau of American Ethnology. Annual Reports. Washington, 1879-1912.

United States Dfpartment of Interior. Contributions to North American Ethnology, Vol. 7. Washington, 1890.

United States War Department. Missouri River Commission. Maps of the Missouri River. Washington, 1892 .

Report of the Secretary of War of a System Providing for the Abolition of Existing Trading Establishments of the United States. Washington, 1818 .

VAN Osdel, A. L. Historic Landmarks; being a history of early explorers and fur traders, with a narrative of their adventures in the wilds of the great Northwest Territory. n. p. n. d.

Van Tramp, J. C. Prairie and Rocky Mountain Adventure; or Life in the Far West. Columbus, 1868.

Victor, F. F. River of the West. Hartford, 1870.

Warren, Lieut. G. K. Explorations in the Dacota Country in the Year 1855. Washington, 1856.

Washington University State Historical Society. Quarterly. Seattle, 1906-1919.

Western Journal and Civilian. Edited by M. M. Tarver and T. F. Risk. 15 vols. St. Louis, $1846-1856$.

Wetmore, Alphonso. Gazetteer of the State of Missouri. St. Louis, 1837.

Wheeler, O. D. Trail of Lewis and Clark, 1804-1806. 2 vols. New York, 1904 .

Wheeler, O. D., Editor. Wonderland. St. Paul, 1896-1906.

Will, G. F., ANd George E. Hyde. Corn Among the Indians of the Upper Missouri. St. Louis, 1917.

Willson, Beckles. The Great Company. Toronto, 1899.

Wilson, F. T. Fort Pierre and Its Neighbors. In Journal of the United States Cavalry Association, 1899, Vol. 12, p. 227.

Wolfrom, Anna. Sacajawea, the Indian Princess. Kansas City, I9r8. Wyeth, N. J. Letters and Journals. In Sources of the History of Oregon. Eugene, 1899.

Young, William. Young's History of Lafayette County, Missouri. 2 vols. Indianapolis, 1910. 
NEWSPAPERS

Boonville (Missouri) Commercial Bulletin. April il, 1846-September 2, 1847 .

Fayette (Missouri) Democrat. Februaty 25, 1846-January 30, 1849. InDEPENDENCE (Missouri) Journal. September 12-October 31, 1844 . Liberty (Missouri) Weekiy Tribune. April, r846-December, 1849. Louisiana Gazette, Missouri Gazette and Missouri Republican. St. Louis, 1808-1845.

Missouri INTElligencer. Franklin, Missouri, 1822-1826.

St. Charles Patriot. May 2, 1846-October 21, 1847.

St. Louis Daily Morning Herald. December 20, 1852-July 2, 1853.

St. Louis Daily Morning Missourian. October 7, 1845-July 28, 1846.

St. Lours Enquirer. September I, 1819-August 30, 1820 .

St. Louis Missourian. December 14, 1843-February 22, 1845 .

St. Louis Reveille. 1845-1848.

Springrield (Missouri) Advertiser. July II, I848-February Io, 1849.

Warsaw (Missouri) Saturdat Morning Visitor. June 10, I848May, 1849 .

Weston (Missouri) Journal (a continuation of the Indepen lence Journal). January 4-April 19, 1845. 


\section{INDEX}

Agot, Gabriel: 158 .

Alar, Jean Baptiste: sketch of, 59; engage, 158.

Alar family: 59 .

Albemarle County, Va.: 150.

Allen, Col. Dewitt C.: 152.

Allison, Hannah: $3 \mathbf{r}$.

Alvarado: 35 .

American Fur Co.: $35,53,59,60$, $77,103,111,148,155,156$.

American Horse, Indian Chief: 57.

American State Papers: cited, 59, 138.

Anderson, John: 158.

Andrew County, Mo.: 38 .

Angel, Eugenia: 148.

Angel, John: ${ }_{4} 8$.

Antelopes: 62.

Antonio, Baptiste Machecou, dit: sketch of, 100; engage, $15^{8}$.

Antonio, Pedro: 100; engagé, 157.

Arapaho Indians: at war with Americans, 15; country of, 16, I 55; villages of, 18, 20; on $\mathrm{Ar}$ kansas River, 76; described, 10I; trade with Sanguinet, I03; sell horses, II4; mentioned, I42.

Archambeau, Louis: killed, i24; buried, 126; engage, 158 .

Arck River: described, 49.

Arikara Fort: I6.

Arikara Indians: at war with Americans, 15; country of, I6; near British posts, 24; villages, 30, 57, 67, 145; chiefs, 64, 77; hunters, 65 ; expedition camped below, 66; war party, 69, 73; attacked Lieut. Pryor's party 74; traders at village, 75; Saones propose peace with, 79; at Fort Manuel, 77, 82, 86, 87, 90, 91, 98, 101, 103, 105, 108, 114,128 ; leave Fort, 84; trade horses, $8 \mathrm{I}$; at war with Sioux, 76, I 13, 120; in search of squaw, 8o; trade corn, 85 ; set prairie on fire, 92 ; threaten Lisa's party, 92; tranquil, 93; steal horses, 93; quarrel with Sioux, I04; hunting, 106; return from Mandans, 107; steal Company's cat, I Io; , offer Lisa a present, IIo; pass by Fort, I I I; kill Sioux chief, II5; want to live at point above Fort, I17; go to Cheyennes for meat, I20; return, I2I; not feared by Lisa, 126; described. 52.

Arkansas River: mentioned, 18 , 51, 70, 100, 102, 103, 138, 145; described, 76 .

Armstead, Montana: 135.

Arnold, Brice: 157.

Arrow Rock, Mo.: 19; blockhouse, 34 .

Ashley, William: $35,73$.

Aspinwall, Neb.: 4I.

Assiniboine River: 136.

Astorians: $38,57,73,77$.

Atchison County, Mo.: 4I.

Atkinson, Gen. Henry: 45, 136, I38, 148 .

Audrin, James H.: 158.

Audubon, J. J.: cited, 9I.

Bad River (sometimes called Little Missouri and Teton): described, 62.

Baird, James: 17, 35 .

Bald-pated Prairie: 42.

Barada, Eulalia: I54.

Bardstown, Ky.: 151 .

Bates, Frederick: I45.

Bates County, Mo.: 50, 52.

Bazile Creek: 53.

Beaux Soleil Island: 4r.

Beckwourth, James: cited, 64.

Beede, Dr. A. McG.: Missionary at Fort Yates, N. D., quoted, $55,56,57,68$.

Bellefontaine: see Fort Bellefontaine.

Bennett, Lieut. Thomas: 154 . 
Bent \& St. Vrain: 140.

Bergan, Marguerite: 79 .

Berger River: described, 29.

Berthelot, Alexis: 102.

Bertrand, Louise: III.

Big Bend (Grand Detour): 57, 61, 98.

Big Elk, Indian chief: 56 .

Big Horn River: described, 77.

Big Horse, Oglala chief: 56 ; sketch of, 57 .

Big Man, Arikara chief: sketch of, 77.

Big Nemaha River: described, 40.

Big Sioux River: described, 47; mentioned, $5 \mathrm{I}$.

Big White, Mandan chief: see Sheheke.

Bijou, Louis: see Bissonet.

Bijou Fork: 140.

Bijou Hills, S. D.: 57, 149.

Bijou's Trading Post: $56,57,58$.

Billeau, dit Lesperance, Jean Baptiste: III.

Billeau, dit I.esperance, Pelagie: III.

Bird Woman: see Sakakawea.

Bismarck, N. D.: 74, 135 .

Bissonet, Joseph: 149.

Bissonet, Louis: joins expedition, 34; makes signal fires, 54; with Yankton Sioux, 56; tradinghouse finished, 58; arrives at Fort Manuel, 79; loads canoe, 80; reported killed, 104, 105; answers Lisa's letter, ro9; sketch of, 148; engage, 158.

Blackbird, Omaha chief: 46,49 .

Blackbird Hill: described, 46 .

Black Buffalo, Teton Sioux chief: sketch of, 56 .

Black Hills: $57,63,70$.

Blackfeet Indians: mentioned, .57, $70,106,144$; reported to have killed Champlain, ro2; described, 102.

Black Snake Creek: 32.

Black Snake Hills (St. Joseph, Mo.): $55,88,147$.

Bledsoe, Anthony: 52.
Black Sky, Sioux chief: $56,5^{8}$.

Blan, Grand: 157.

Blood Indians: 102.

Bloomfield, Mo.: 52.

Bois Brule Indians: 57 .

Bois, Catherine des: 79.

Boite, Sioux chief: 82 .

Boller, H. A.: cited, 105.

Bolton, Herbert E.: 143 .

Bonhomme County, S. D.: 49, 54 .

Bonhomme Island: described, 49.

Bonhomme Township, Mo.: 28 .

Boone District: 123 .

Boonslick, Mo.: 19.

Boonville, Mo.: 3 I.

Boucherelle, Alphonzo: 88.

Bougainville, Charlotte Pemanpieh: 52 .

Bourbonnois, Auguste: 158.

Bourgmont, Etienne Venyard de: 32.

Bourrain, Josef: 158 .

Bow Creek: 49, 5 I.

Boyer River: described, 44.

Brackenridge, H. M.: cited, 44, $46,49,67,73,77,133,136$.

Bradbury, John: cited, 136, 145.

Bras Cassé, Sioux chief: 57.

Brawn (Brown), William: is7.

Brazeaj, Cecile: 150.

Bridger, James: 140.

Bridger Range: 135 .

Bright, Josiah: 150.

British agents: 23, 24, 122, 124. I53.

British North West Company: 15.

Broken Arm, Indian chief: 57.

Brown County, Kans.: 40.

Brown, Widow: 148.

Brownsville, Neb.: 4 I.

Bru!é County, S. D.: 57.

Bryant, Edwin: cited, 35 .

Buchanan County, Mo.: 147.

Buffalo County, S. D.: 61.

Bullet (Cannon Ball) River: described, 107.

Cabanne \& Co.: 144 .

Cabre: 62 . 
Cadron, Etienne, dit St. Pierre: I 57.

Cahokia, Ill.: 79, 80, 89, 154 .

Caledonia, Ill.: I46.

Calhoun, Neb.: 45 .

Callaway, Capt. James: 35.

Callaway County, Mo.: 30.

Campbell, Robert: 152.

Campbell, William: 152.

Canga, Antoine: I 57.

Cannonball River: mentioned, 52, $67,107$.

Cape Girardeau, Mo.: 51, 129.

Carboneau, Elizabeth: 140.

Carlyle, Ill.: 146.

Carondelet, Mo.: 29, 91.

Carriere, Baptiste: 77.

Carriere, Eustache: on fall hunt, 77; sketch of, 77, 79; reported killed, 98; engage, 157 .

Carriere, Michel: 77 .

Carrollton, Ill.: 146.

Cass County, Neb.: 4 I.

Casse, Emelie: 114 .

Casse, Joseph Laderoute, dit: see Laderoute.

Castor River: 52.

Castro: 35 .

Catlin, George: 74 .

Cats in trading-posts: 62, 63.

Cedar County, Neb.: 45, 49 .

Cedar Creek: 6I.

Cedar Island: $46,6 \mathrm{r}$.

Cerré, Gabriel: II4.

Chabonard: I40.

Chahik-si-chakiko: 69.

Chaine, Isadore: 89.

Chaine, Pierre: sketch of, 89; engaged to hunt, 91 ; sent for stolen horses, 93; hunting, 94, 99; goes to Cheyennes' camp, 97; engagé, 158.

Chambers, Samuel: 17,35.

Chambersburg, $\mathrm{Pa}$ : 143 .

Champlain, Jean Baptiste: leader of party, 16, 17, 142; on Platte, 18; death of, 19: search for, 20; reported killed by Blackfeet, IO2; sketch of, 102.

Chappell, Phil E.: cited, 29, 32.
Charbonneau, Jean Baptiste: 134, 140.

Charbonneau, Lizette: 133, 140.

Charbonneau, Toussaint: 24; alarms Fort, 78; goes to Grosventre station, $79,86,89,127$; returns, 83, 92; to Saone camp, 97; stirs up Indians, 84; at Arikara village, 93 ; prepares to trade with Grosventres, I09; returns from village, I21; warnings to, 124; wife dies, 126; escort returns, 128; husband of Sakakawea, 132; wives of, 133; children of, 133, 134, 140; sketch of, 135; pay as interpreter, 140; engage, 158.

Charbonneau, Toussaint, Jr.: 133.

Charbonniere: described, 28.

Charles, Mary: I42.

Charles, a Negro boy: drowns, 59 .

Charrette: see Jarret.

Charlottesville, Va.: $15 \mathrm{I}$.

Chatelreau, Louis: 158.

Chemin River: 153.

Chene: see Chaine.

Cherokee Indians: 151 .

Chevalier, Cadet: in search of Champlain's party, 20, 1 ro, 158 ; messenger, IOI; sketch of, IOI; goes to meet Sanguinet, 103; death of, I10; engage, I57.

Chevalier, Louis: IOI.

Chevelures ("The Scalps"): ro4.

Cheveux Loup, Grosventre Indian: 92, 122.

Cheyenne Indians: at war with Americans, 15; attacked Kansas Indians, 37; mentioned, 63,86 , 'IOI, I12; at Fort Manuel, 70, 98, 106, 120; described, 70; chiefs, 92, 108, I20; camped above Fort, 97; hunting, 99, 100; leave Fort, 107; carry pipe to Arikaras and Sioux, 113; fight with Sioux, 115; advise Arikaras to leave Fort, I2I; warn Charbonneau,. 124; difficult to trade with, 125; Sioux steal horses from, 127 . 
Cheyenne River: mentioned, 52, 64; described, 63,70 .

Chicago, Ill.: first settler of, 153 , I54.

Chicago River: I53.

Chihuahua: 36,823 .

Chippewa Indians: 54 .

Chittenden, H. M.: cited, 16, 50, 5 I, 68, 76, 94, 106.

Chouteau, A. P.: 43, 138.

Chouteau, Auguste: 13, 28, 43, 91, $102,138,145,148$.

Chouteau, Matie Louise: 53 .

Chouteau, Pierre: 28, 50, 102.

Chouteau Bluffs, S. D.: 54.

Chouteau, Cabanne \& C?.: III.

Chouteau-DeMun expedition: 70 , $103,138$.

Cija, Osage Indian woman: 30.

Citoleux, Antoine: I09, I10; sketch of, 156; engage, 157 .

Citoleux, Jean B.: ${ }_{15} 6$.

Clart, George Rogers: 153.

Clark, William: employs John C. Luttig, 14; chose site of Fort Osage, 34; council with Indians, 56; guardian of Charbonneau children, I34; letter to Charbonneau, 137; deed to, 138; report to, 144 ; recommends Reuben I ewis, 150.

Clay County, Mo.: 151, 152.

Clay County, S. D.: 48.

Clemson, Col. Eli B.: in command of Fort Osage, 34; sketch of, I45,

Clemson family: 146 .

Cold Water Creek: 2 ?.

Cole, Mrs. Hannah: sketch of, 31 .

Cole, Stephen: 31 .

Cole, William T.: killed by Indians, 31 .

Cole family: $3 \mathbf{I}$.

Cole County, Mo.: 65 .

Colter, John: 65,145 .

Columbia Fur Company: 62.

Condé, Marie Anne: 149.

Condé, Dr. Auguste A.: 149.

Cooper, Miss Alice: 135 .

Cooper County, Mo.: 3I, 65 .

Corson County, S. D.: 66, 67, 68.
Côte, Alexis: 9I.

Côte, Felicite: 9r.

Côte Grand Brulé: 42.

Côte sans Dessein: described, 30.

Coues, Flliott: cited, 29, 38, 43, $44,87$.

Council Bluffs: $16,44,148,151$; described, 45 .

Council Grove: 37 .

Coupé a Jacques: 44.

Coupé Ioisell: described, 45 .

Coyner, D. H.: mentioned, 19.

Crawford, T. Hartley: letter to, 141.

Crawford County, Iowa: 45 .

Crawford County, Mo.: 65 .

Creek Indians: roo.

Cromwell: 13r.

Crooked Hand, Sioux chief: 57, II3.

Crooks, Ramsey: 44 .

Crow Indians: at war with Americans, 15 ; give information about Champlain, 20; mentioned, 35, 68, 100, 103, 106; described, 78 .

Dabney, Mildred: 151 .

Dakota City, Neb.: 51 .

Dakota County, Neb.: $47,49$.

Dakota Indians: 51 , 57; described, 54.

Danis, Charles: 100.

Danis, Jean Baptiste: sketch of, 100.

Davenport, Iowa: 155.

Delassus, Gov. Carlos Dehault: 88, 144 .

Dejardin, L. T.: 158.

Delaware Indians: 52.

Delibac, Louis: 158.

Delisle, Jean Baptiste: 147.

Delisle, Therese Bienvenue: 147.

Demarais, Louis Amable: 43.

Demaret, Josette: 29.

De Mun, Julius: 138 .

De Peyster, Arent: 153.

Derais, Michael: 154 .

Desgagniers, Catherine: 77.

Desmarets, Louise: 59.

Desmarets, Joseph: 59. 
De Smet, Pierre J.: cited, 106.

Des Moines River: 45, $5 \mathrm{I}$.

Dessaint, Louis: 155 .

Desseve, Pierre: I 57.

Detalier, Pierre: 157.

Detroit, Mich.: III, 145.

Devil's Lake, N. D.: 49.

Dickson's Post: 49.

Dixon County, Neb.: 48.

Dodier, Elizabeth: 9r.

Doniphan County, Kans.: 40.

Dorien Island: 6r.

Dougherty, Maj. John: 65, I57; sketch of, $15 \mathrm{I}$.

Dougherty, John Kerr: I53.

Dougherty, Lewis B.: 153 .

Dougherty, O'Fallon: 153 .

Douglas, Walter B.: acknowledgments to, 25; cited, 65, 142.

Drouillard, George: 78,1 I I.

Dubuque, Iowa: 13.

Dubuque, Julien: mentioned, 13, ro3.

Duncan: 131 .

Dupre, Eugene: 53.

Duquette, François: 60 .

Durand, British trader: 153.

Durocher, Auguste: carries message, Ior; no news of, ro4; reaches Fort Manuel, ro5; leaves for Little Big Horn, III; returns, II2; ordered out of Fort, II4; escorts Charbonneau, 128; sketch of, 155 .

Durocher family: 155 .

Eagle's Feather (Plume d'Aigle), Arikara chief: see La Plume.

Eagle Feather Creek: 67.

Elie, Joseph: sketch of, 79.

Elk's Tongue, Arikara chief: sketch of, 91; camp of, 93.

Engineer Cantonment: 44.

Equipment for hunters: 76 .

Eymas, Jean: 156, 157.

Fair Sun Island: 41 .

Farrar, Dr. John: 43.

Ferguson: 131.

Fire Heart Butte, N. D.: 97.
Fire Prairie: described, 33.

Fire Prairie Creek: 33.

Fishing Creek, S. C.: 65 .

Flathead Indians: 106.

Florissant, Mo.: $28,59,77,79,88$, III, 124 .

Floyd's Bluffs: 47.

Floyd's River: described, 47.

Fontaine, Philip: 158

Fort Anthony: 122.

Fort Atkinson: 45 .

Fort aux Cedres: 53 .

Fort Bellefontaine: 27, 63, 123, $144,146$.

Fort Bent: 76 .

Fort Benton: 89 .

Fort Berthold: 52, 64, 74, 135, 155.

Fort Bridger: 140.

Fort Calhoun: 45 .

Fort Clark: 33, 148.

Fort Clemson: 146 .

Fort Cole: 31.

Fort Fiery Prairie: 33.

Fort Kiowa: 156.

Fort Laframboise: 62 .

Fort Laramie: 54, 55 .

Fort La Salle: 70.

Fort Leavenworth: 34, 152.

Fort Lisa, near Council Bluffs: 16, $44,144$.

Fort Madison: 27.

Fort Mandan: 15, 79, 142.

Fort Manuel: 17, broken up, 20; location of, 68; cleared for defense, 93, 125; enclosure finished, 93; baptized, 94 .

Fort Mason: 123.

Fort Massac: 27.

Fort Orleans: 32.

Fort Osage : 27, 146, 150; described, 33; hunters at, 35 .

Fort Pembina: 136.

Fort Pierre: $55,137$.

Fort Pine: 136.

Fort Raymond: 77.

Fort St. Michel "chez des Sioux": $6 \mathrm{I}$.

Fort Snelling: 122.

Fort Tecumseh: 62, 77 . 
Fort Union: 77,155 .

Fort Vincennes: 27.89.

Fort Yates: 68, 124.

Foster County, N. D.: 49.

Fouché, François: III.

Fouché, Isaac: sketch of, 111 ; engage, 158.

Fouché, Michel: II I.

Fouché, Pedro: III.

Four-Mile Creek, N. D.: 91.

Fowke, Gerard: cited, 32.

Fox Indians: 27.

Franklin County, Mo.: 31, 144, 145.

Franklin, Mo.: I 50.

Franklin, Tenn., battle of: 153 .

Fremont, John Charles: cited, 45 , 140.

French Fur Company: 148.

Fulkerson, W. N.: I 38 .

Gage County, Neb.: 40.

Galena, Ill.: 142, 150.

Garciniere, Don Andres Fagot la: 64 .

Garreau, Antoine: 64 .

Garreau, Joseph: sketch of, 64; returns from Arikaras, 68; wife threatens to shoot, 84 ; leaves Fort, 90; deception of, 92; orders Arikaras to steal horses, 93; returns to Fort, 94; at Saone camp, 97; invites Sioux to go hunting, I04; goes to meet Immell, I07; to Arikara village, I17; engage, 158 .

Garreau, Pierre: 64 .

Gauche (Left-handed), Arikara chief: visits camp, 64; sketch of, 64 ; receives present, 66 ; follows expedition, 67; at Fort, 72, 79, 86, 89, 99, 106; mentioned, 73, 128; horse stolen by Sioux, 83; holds council, 93; village of, 100; carries pipe to Cheyennes, I Io; returns from Cheyennes, 112; wants to live near Fort, 117; returns from hunt, I 18; son blind, 120.

Geyer, Senator Henry S.: 152.
Glineau, Nicolas: sketch of, ro3; goes to Mandans, 109, 1 19; recovers stolen horses, I16; engage, 158.

Goyet, Marie: 34 .

Graham, Moses: 14.

Grand Detour: 6r.

Grand Pawnee Indians: 69.

Grand River: mentioned, 32, 52, 64, 67; described, 65 .

Great Bend: $6 \mathrm{r}$.

Greenwood, Caleb: sketch of, 35 ; goes to Arikaras, 6I; rejoins party, 65; engage, 157 .

Gregory County, S. D.: 55, 56.

Grey Eyes, Arikara chief: sketch of, 73; at Fort Manuel, 76; mentioned, 91; has Company's horses, 93, 94; returns horses, 98.

Grey Head, Mandan chief: 90.

Grier, Robert C.: 53 .

Grosventre Indians: at war with Americans, 15; Hidatsa, 52; post of, 63; kill an Arikara, 68; described, 68; mentioned, 69, 84, 106, 136; trade horses, 73; traders return from, $74,87,121$; steal horses, 78; kill Mandan chiefs, 83 ; send pipe to Arikaras, 87; battle, 88; traders with, 89; go to Arikaras, 93; kill trappers, ror; Sioux kills, ri8; capture Bird Woman, I32; battle between Mandans and Grosventres, 139.

Grosventres of the Prairie, or Fall Indians: 102.

Hall, Rev. C. L.: cited, 132.

Hannibal, Mo.: I23.

Harding County, S. D.: 66.

Harmony Mission: 51, 60 .

Harnois, Pierre: 155.

Harper, Mr.: 151.

Harrison, William Henry: Governor of District of Louisiana, 27.

Harrison County, Iowa: 45 .

Harrison, Mo.: 100. 
Hartland, Kans.: 70.

Head, James: 100 .

Hebard, Dr. Grace R.: 135.

Helie: see Elie.

Hempstead, Stephen: 142.

Henry, Alexander: cited, 68, 73, I36.

Henry, Andrew: 65, 104.

Hertzog, Joseph: 153 .

Hertzog, Mary: 152.

Hidatsa group: 78 .

Hidatsa Indians: see Grosventre Indians.

Hidatsa language: 133.

Hight, Henry: I54.

Hodge, F. W.: cited, 51, 52, 58, roo, ror.

Holmes, Capt. Reuben: 138.

Holt County, Mo.: 38.

Hopa-wazhupi: 49.

Hortiz, Joseph: Ior.

Hortiz, Marie L.: 155 .

Hosmer, James K.: cited, 135.

Hotonga: 51 .

Howard, Gen. Benjamin: 123.

Hunkpapa Indians: 57.

Hunt, Col. Thomas: 27, 144.

Hunt, Wilson P.: 64.

Hyde County, S. D.: 6r.

Ichinipokine River: 41.

Ida County, Iowa: 45.

Illinois River: 70.

Immell, Michael E.: meets expedition, 27; goes to Fort Osage for dog, 35 ; precedes party by land, 51; with Sioux, 54, 56; returns to camp, 58; at Grey Eyes' camp, 94; hunting, 60, 80, 81, 91, 92, 99; returns from hunt, 82; visits his wintering post of $1811,6 \mathrm{r}$; letter from, 64 ; at Arikara village, $83,85,93$; goes to Grosventre village, 86 ; to Cheyenne camp, 97; attends Cheyenne feast, 98; to Mandans, 103, 104, 119; reported robbed by Cheyennes, 107; goes to Sioux camp, 108; in search of stolen horses, I12, 116; re- turns with horses, I13; gives girl to Laderoute, 115; helps Arikaras move, 117; returns from Mandans, 120; reconnoitres, 126; sketch of, 143; engagé, 157.

Indian chief fires his gun backward: 108.

Indian spies: 56.

Indian Territory: $37,5 \mathrm{I}$.

Indians designate site of tradingposts: 67.

Inkpe Luta, Indian chief: 57 .

Iowa Creek: 48.

Iowa Indians: $23,37,51$.

Iowa Point: 40.

Irving, Washington: cited, 64 .

Isle a Beau Soleil: 4I.

Istinhmunma (The Sleeper), Indian chief: 55 .

Jackson County, Mo.: 33.

Jacques (James) River: described, 49; mentioned, 51

James, Thomas: cited, 68.

Janot: see Lachapelle.

Jarret, Henry: 88.

Jarret, Susanne: 88

Jefferson, Thomas: 52.

Jefferson Forks: 135 .

Johnson, William J.: 88.

Johnson County, Neb.: 40.

Jollet, Alexy: 157 .

Jones, Robcrt: 144.

Joyal, Antoine: 88.

Joyal, Joseph: sketch of, 88 ; with Glineau, 104; engagé, 158.

Joyal family: 88 .

Jusseaume, Josette Therese: 77, 79.

Jusseaume, René: mentioned, 74, 77, 137; sketch of, 79; returns from Grosventre village, 83 ; excites Indians, 84; with Glineau, 104; horses stolen, I16; engagé, 158.

Jusseaume, Toussaint: 79.

Kago-ha-mi (Little Raven or Little Crow), Mandan chief: 83 . 
Kansas City, Mo.: 36, 147.

Kansas Indians: imprison Ezekiel Williams, 19, 35; described, 36 ; mentioned, 50 ; villages, 35,36 .

Kansas Outfit: 155 .

Kansas River: mouth of, 23; mentioned, $36,37,51,70,78$, 101.

Kansas State Historical Society: I57.

Kaskaskia, Ill.: records, 30; mentioned, 77, 80, 100, 114 .

Kearny, Stephen W.: 64, 123, 136, 138.

Kearny County, Kans.: 70.

Keeney, Mrs. Mary Hempstead: 142.

Kenel, S. D.: 68.

Kennerly, George: 144.

Kennerly, James: 130 .

Kenton, John: 157.

Kinzie, Mrs. John H.: 153.

Kipp, James: 137.

Knife River: 68, 136.

Knox County, Neb.: 49, 53, 54 .

Labadie, Joseph: 88.

Labadie, Therese: 88.

Labonté, Antoine: 157.

Labuiche, Genevieve: 88.

Lachapelle, Bazile: 30 .

Lachapelle, David: 30.

Lachapelle, Jean Baptiste: sketch of, 30; kills bear, 32; on hunt, 77; reported to have been killed, 98; engage, 157 .

Lachapelle, dit Janot: 30.

Lacroix, Paul: 9 I.

Laderoute, Joseph: ordered out of Fort, II4, I15; sketch of, $\mathrm{II}_{4}$; deserted, I17; escorts Charbonneau, 128.

Ladouceur, Elinore: 149.

Ladouceur, Pierre: 149 .

Lafayette County, Mo.: 33.

Lafarque, Jean: leader of party, 16,$142 ;$ in Spanish country, I02; sketch of, 103 .

Lagasse, Josef: 157.

La Garciniere, Don Andres Fagot: 64 .
Laidlaw, William: 137 .

Lajeunesse, _ tion, 34 .

Lajeunesse, Jacques: 34 .

Lajeunesse, Jean B.: 34 .

Lajeunesse, Marie: 77.

Lajeunesse family: 34 .

Lajoie, Joseph: 88.

Lajoie, Louis: sketch of, 88; engagé, 157.

Lake Nepegon: ror.

Lake Winnepeg: III.

Lamberton, N. J.: 123.

Lamonde, Pierre: 157.

Lancaster County, Neb.: 40.

Lange, Joseph: III.

Lange, Pierre: arrives at Fort, IIO, III; goes to Mandans, Ir9; engage, 157.

Langue de Biche (Elk's Tongue), Arikara chief: sketch of, 9r; camp of, 93; horses recovered recovered from, I16; situation of, 126; at Fort, 128.

Lapere, Cecile: 148.

Lapere, Peter: 148.

La Plume d'Aigle (Eagle's Feather), Arikara chief: sketch of, 67 ; at Fort, 72, 75, 93, I20; carries pipe to Mandans, I ro.

Laprise, François: 157.

Laprise, Joseph: 155 .

Larivier, Pierre: 157.

Laroche, Marie J.: 89.

Larocque, François Antoine: 137.

Larose, Cecile: 147.

Larpenteur, Charles: cited, 64,89 .

Larrison, Daniel: sketch of, 35; engage, 158.

Larrison, John: 35 .

Latour, Amable: II r.

Latour, Charles: in search of Champlain's party, 20, 158 ; arrives at Fort Manuel, Iro; sketch of, 110 ; ordered out of Fort, II4; accompanies Charbonneau, 128; engagé, 157.

Latour family: III.

La Tulipe: 43 .

Latulippe, Elizabeth: 43. 
Latulippe, François: 43 .

Latulippe, Jean Baptiste: sketch of, 42; engagé, 157.

Laviolette, Catherine: 59 .

Laviolette, Julia: 59 .

Laviolette, Marie L.: 139.

Lawrence County, Ark.: I4.

Lawrencetown, Ark.: I4.

Lean Wolf, Indian chief: 140.

L'Eau Qui Court (Niobrara) River: described, 53; mentioned, 144.

L'Eau Qui Monte: 53.

Leavenworth, Col. Henry: 122.

Lebanon, Ill.: 146.

Leblond, Joseph: 156.

Le Borgne (One-eyed), Grosventre chief: sketch of, 73 ; mentioned 121; in disgrace, 122.

Leclair, Joseph: 127, 157 .

Leclerc, Therese: III.

Lecompte, François: sketch of, 78 ; engagé, I 57.

Lecompte, Louis: 148.

Leduc, Morice: 158 .

Le Grand, Cheyenne Indian: 87.

Le Grand (Partizan), Dakota warrior: 90.

Le Gross (Big Man); Arikara chief: sketch of, 77; at Fort Manuel, 89,94 , 106; returns from Cheyennes, 119.

Leme, Josef: 157.

Lemonde, dit La Malice, Charles: 148.

Le Nez (The Nose), Sioux chief: sketch of, 55 .

Lepage, Julia: 59 .

Leroux (or Ledoux), Abraham: I 57.

Leroux, Antoine: 157.

Lessaroco, Cheyenne chief: 86.

Le Sueur, Minn.: 57.

Lewis, Meriwether: 74, 139, 150.

Lewis, Reuben: 60; prairie dog, 71; on Little Big Horn River, 77, 101; message from, 100, 105; letter to, III; sketch of, 150; in list of engages, 157.

Lewis, T. H.: cited, 56.
Lewis and Clark Expedition: men tioned, 11, 29, 32, 34, 37, 38, $42,44,45,48,49,5 \mathrm{I}, 62,64,70$, $73,87,90,102,106,136,140$, 145; map of, 53; held council with Indians, 56; quoted, $5^{8}$; at Arikara village, 67; gave Le Borgne a swivel gun, 73; at Fort Mandan, 79, 83; interpreter for, 132.

Lexington, Mo.: 153 .

Liberty, Mo.: I 51 , I 53 .

Lisa, Cristobal de: I42.

Lisa, Manuel: returns to St. Louis, 15, 16; expeditions of, 17, 29, 35; sends Company's boat back, 52; difficulties with Indians, 18, 19, 92, 93; trade with Southwest Indians, 20; success of, 2 r ; strategy of, 23; joins expedition at the Charbonniere, 28; puts hogs in river, 38 ; escapes drowning, 46; monopoly of Osage trade, 50; holds council with Indians, 56,66 ; servant drowns, 59; gives presents to chiefs, 58 , 74, 120; trading-posts of, 61, 66, 68,77 ; sends for cat, 62 ; fort at Grand River, 66; injured, 69; goes to Grosventre village, 69 ; returns, 70, 73; talk with Sioux chief, 77; partnership with Drouillard, 78 ; proposes peace between Saone and Arikara Indians, 79; at Arikara village, 83 ; engages Charbonneau, 86; takes pipe of Grosventres to Arikaras, 87; with Saone Sioux, 90; urges Arikaras to hunt, 92; at Cheyennes' camp, 97; invited to Cheyenne feast, 98; hunting, 99; employees of, 100, 102, 103, I I I, II4; sends letter to Bijou, 105; promises horses to Arikaras, 106; men return, 107; offers friendship to Sioux, Io8; receives unpleasant news from Lewis, 100; letter from Sanguinet, Ior; refuses present from Arikaras, I Io; urges men to 
hunt, II4; running mare stolen, I16; takes possession of Indian fort, I I6; gives presents to cover the body of Gauche's son, 120; sketch of, I4I; letter to Spaniards, 142; mentioned, 144 .

Lisa, Rosalie: 142.

Little Berger River: 29.

Little Big Horn River, 77, IOI, I I I, 142.

Little Bow Creek: 49.

Little Bow, Omaha chief: 49.

Little Cedar Island: in Gregory County, S. D., 55.

Little Cheyenne River: described, III.

Little Crow, Mandan chief: killed by Grosventres, 83 .

Little Missouri River (now called Bad River): 75, 156 , 157.

Little Nemaha River: described, $4 \mathrm{I}$.

Little Platte River: described, 36.

Little Osage Indians: village of, 32; mentioned, 50, 51 .

Little Osage Island: location of, 32.

Little Osage Prairie: described, 32.

Little Osage River: 50.

Little Sioux River: described, 45.

Loisel, Josephine: 53 .

Loisel, Regis: $46,53,61$.

Long, Major S. H.: 44.

Lorimier, Guillaume de: 52.

Lorimier, Louis: precedes party by land, $5 \mathrm{I}$; sketch of, $5 \mathrm{I}$; meets Sioux Indians, 55; goes by land to Arikaras, 6I; rejoins party, 65; at Little Big Horn, 77, ror; at Crow v:llages, I00; letter from, ro5; letter to, III; engage, 157 .

Lost Creek: 53.

Loutre Island: 31 , I46.

Louisiana Purchase Exposition: I35.

Lovely, Major William L.: I4.

Lucas, J. B. C.: 146.

Luipere River: 53 .

Lumandiere, Marie: 30.
Luttig, Elizabeth: I4.

Luttig, John C.: clerk of Missouri Fur Company, 12; merchant in Baltimore, I3; death of, I4; journal entries referred to, 18 , 19, 55, 67; accepts present from Arikaras, 110; throws present away, I I2; letters to, I29-131 ; guardian of Charbonneau children, 133; contempt for Charbonneau, 137; engage, 157 .

Lyman County, S. D.: 55, 61 .

Machecou, dit Antonio, Baptiste: sketch of, 100; leaves Little Big Horn River, ror; goes to meet Sanguinet, 103; equipped for hunt, III; ordered out of Fort, I 14; returns, I27; escorts Charbonneau, 128; engage, 158 .

McClellan, Robert: 44,78 .

McDonald, Henriette: 146.

McDowell, Mr.: I48.

Mackinac: 148, 153, 154 .

McKnight, Robert: 17, 35 .

McKnight-Chambers-Baird Expedition: 17, 20, 35 .

McKraken, Louis: 157.

McMines: I29.

Malbœuf, Elizabeth: 34 -

Malbceuf, François: 34 .

Manaigle: see Manegre.

Mandan Fort: I5.

Mandan Indians: near British posts, 24; villages of, 15, 79; allies of Arikaras, 52; mentioned, $57,68,104,133,136,138$, 139, 140, 148; described, 74; houses of, 75; at Fort Manuel, $81,87,90$, 108, 112, 128; steal horses, 83; demand a trader, 99 ; Mandan chief, 146.

Mandan, N. D.: 74 .

Manegre, Joseph: 80.

Manegre, Louis: sketch of, 80; engagê, 157.

Maryland records: 13.

Marais des Cygnes: 50.

Marechal, François: III.

Maria's River: 102. 
Marmiton River: 50.

Marasse, Pierre: 157.

Marks, Dr. John: I 5 I.

Marquette's map: referred to, 50.

Mason, Lieutenant John: I23.

Masquilonge, Quebec: 88.

Matson, N.: cited, 153.

Matthews, Dr. Washington: cited, $78,132$.

Maximilian, Prince of Wied: cited, $30,64,68,78,136,137$.

Mayet, Jean Baptiste: sketch of, 29; cuts pickets for fort, 82, 86; engagé, 157.

Medicine Men, Cheyenne chief: 99.

Manier, Agnes: II I.

Mercier, Antoine: sketch of, 77; reported to have been killed, 98; engagé, $\mathrm{I} 57$.

Mercier, Joseph: 77.

Merrill, Rev. Moses: 35 .

Metaharta village: 136 .

Mexican War: 146.

Micheltorena's Army: 35 .

Michigan City, Ind.: 153 .

Mine d'Espagne (Dubuque, Iowa), 13.

Minneconjou Indians: 57.

Minnesota Historical Society: 90.

Minnetarees: see Grosventre Indians.

Mississippi River: 5I; Upper, 23.

Missouri Fur Company: mentioned, II, I3, I5, 30, 35, 55, 64, $77,79,80,89$, 100, I I I I I I4, I43, $144,149,156$.

Missouri Ga7ette: 14, 15, 17, 144,

Missouri Historical Society: Archives, II, 12, 137; Collections, $17,53,123$.

Missouri Indians: $32,37,51$.

Missouri Intelligencer: $5 \mathrm{I}$.

Mis.rouri Republican: I52.

Missouri River: Indians on, 23.

Missouri River Commission maps: cited, $45,48,53,97$.

Mitchell, Major D. D.: 138.

Mohaw River: see Omaha River. Monier, Jean Baptiste: 50.
Monona County, Iowa: 45.

Montana Daughters of American

Revolution: 135 .

Montreal, Canada: 30.

Moore, James C.: 129, I3I.

Moreau River: 64.

Moreau Township, Cooper County, Mo.: 65.

Morton County, N. D.: 9r, 97, I07.

Mosquito Creek: described, 44.

Muhlenberg County, Ky.: 65 .

Murray, Charles Augustus: cited, 30.

Nadeau, Mrs. Virginia: 150.

Nadowa: see Nodaway, 38.

Napoleon, Ill.: 146.

Naulette, René: 34 .

Neil, Rev. Francis: 134, 140.

Nelson County, Ky.: 151 .

Nemaha County, Kans.: 4I.

Nemaha, Neb.: 4r.

Nemaha River, Big or Great: described, 40.

Nemaha River, Little: described, 4I.

Neosho River: 51 .

New Brunswick, N. Y.: 146.

New Madrid County, Mo.: Io0, III.

New Mexico: 17 .

New Orleans: 13, 149.

Nez de Corbeau, Sioux chief: sketch of, 72 ; receives present, 74; at Fort, 81, 82.

Nez Percés Indians: 106.

Nicollet's Map: referred to, 48, 53.

Niobrara River: Poncas on, 50; described, 53; mentioned, 54, 57 .

Nishnabotna, Mo.: 41 .

Nishnabotna River: described, 41 .

Nodaway, Mo.: 38.

Nodaway River: escribed, 38.

Norman, Louis: 158.

North West Company: $15,64,78$, 79,88 , 104, II I, I22, I 36, I49. 
O'Fallon, Benjamin: 144, 152.

Oglala Indians: 57,58 .

Ohheenaw (Le Grand), Cheyenne Indian: 87.

Olden, Mary C.: 146.

Oliver, Ann Marie: 146.

Olmstead, Il!.: 146.

Omaha Indians: villages of, 48 , 49; mentioned, 50, 54 , II5, I48; described, 51 .

Omaha River: 47.

One-eyed, Grosventre chief: sec Le Borgne.

Ooheneonpa Indians: 57.

Ordway, Sergeant John: 48.

Osage Indians: rescued Williams from Kansas Indians, 19,35 ; mentioned, 32, 150; described, 50, 51 .

Osage River: 43, 50, 5I, 60, ror.

Otter Woman: wife of Toussaint Charbonneau, 133 .

Otoe Indians: 35,37 , III; described, $5 \mathrm{I}$.

Owl River: 64 .

Oulle, Antoine: 89.

Oulle, François: sketch of, 89; hunting, 99; goes to Grosventre village, IO9; returns, I2I; engagk, $\mathrm{I} 58$.

Packs of furs: 74 .

Papilliar, Cheyenne chief: 92.

Papillon Creek: 44.

Papillon, Neb.: 44 .

Papin, Hypolite Leber: in charge of Company's boat, 52; goes to Grosventre village, 86; to Arikara village, $87,92,93$; at Grey Eyes' camp, 94; goes to Bijou's trading - post, I05; meets Immell, 107; goes to Langue de Biche's camp, I16; sketch of, 53; engagé, 157.

Papin, Sophie: 88.

Papin, Sylvestre: 53 .

Papin family: 53.

Papinsville, Mo.: 50.

Pariki (a horn): 69.

Parkman, Francis: 149.
Parkville, Mo.: 36.

Partizan, Saone Sioux Indian: 90.

Paston: I30.

Pasu Ksapa (Le Nez), Sioux chief: 55 .

Patron: 29, 42.

Pawnee County, Neb.: 40.

Pawnee Indians: mentioned, 37, 57, 101; described, 69.

Pawnee Island: 54 .

Pawnee village: 30 .

Pawnee Loup (Skidi) Indians: 69.

Pelletier, Jean B.: 154.

Peltier, Antoine: 157.

Penny, Margaret: 52.

Peoria, Ill.: 154.

Pere, Mr.: 103.

Pereau, Paul: 158.

Polly, John: 157.

Perkins County, S. D.: 66.

Perrin, Catherine: 89.

Perrin du Lac's map: cited, 45, 53.

Perry, Robert: 47 .

Perry Creek: 47.

Peru, Neb.: 4I.

Petit Arc Creek: 49.

Petite Cotes: see St. Charles.

Petite Riviere des Sioux: 45.

Petite-sas-Plains: 32.

Philibert, Edmond: 155.

Philibert, Joseph: 155 .

Piegans Indians: 102.

Piaheto (Plume d'Aigle, Eagle's Feather), Arikara chief: see La Plume.

Picard, Helene: 34 .

Picard, John: 88.

Pike, Lieutenant Zebulon M.: 43, 57; expedition of, $43,50,72,90$; sketch of, 123.

Pike County, Mo.: 123.

Pike's Peak: 76, r23.

Pilcher, Joshua: letter from, 139 .

Pilon, Rosalie: 156.

Pipestonc, Minn.: 5 I.

Platte County, Mo.: 36.

Platte River: described, 43; mentioned, 18, 51, 57, 69; North Platte, 57, 91, 138. 
Plume d'Aigle (Eagle's Feather): see La Plume.

Plus: 125.

Point du Sable, Jean Baptiste: sent for stolen horses, 93 ; sketch of, 153; engagé, 157 .

Point du Sable, Jean B., Jr.: death of, 154.

Point du Sable, Susanne: 154 .

Point Jacques: 44 .

Point Labadie, Mo.: 144.

Ponca Indians: described, 50; mentioned, 5 I, II 5 .

Ponca Creek: described, 54.

Poor Little Wolf, Cheyenne Indian: 99.

Portage des Sioux: 56, 90 .

Portageville, Mo.: 100.

Porteau: 18, 20.

Pottawattamie County, Iowa: 44, 45.

Potter County, S. D.: III.

Potts, John: 102.

Poulin, Isadore: 148.

Poulin, Mary: 147.

Portland, Oregon: 135.

Pourcelle, A.: I29, 131 .

Prairie du Chien: 59.

Prairie du Feu: 33.

Prairie du Rocher: 59.

Pratte \& Vasquez: 148.

Prevost, Jean Baptiste: sketch of, 90; turned out of Fort, 9x; arouses the Arikaras, 92; accused of inciting the Indians, 93; explains his conduct, 94; pardoned by Lisa, 99; engagé, 157.

Primeau, Paul: 149.

Primeau, Pelagie: 149.

Primeau, Pierre: 158.

Princeton, N. J.: 146.

Provenchere, Peter: 103.

Pryor, Nathanjel: 57,74 .

Pulaski County, Ill.: I46.

Quapaw Reserve: 151.

Quebec, Canada: 149.

Quenneville, François: hunting,
60,61 ; sketch of, 60; engage, 157.

Quenneville family: 60 .

Rajotte, François: III.

Raven Nose, Sioux ch ief: see Nez de Corbeau.

Red River: 24, 47, 64, 70, 79, 88.

Red Shield, Indian chief: 73 .

Reevey's Prairie: 38.

Republican Pawnee Indians: 69.

Ribeau, Agathe: 88.

Richardson, Amos: 29; sketch of, 144.

Richardson, Daniel: 144, 145.

Richardson, Nancy: 144.

Richardson, Richard: 145 .

Richardson County, Neb.: 40.

Richwoods, Mo.: 139 .

Riddle, Mrs. Esther Daniels: 146 .

Riddle, James: 146.

Rio del Norte: IOr.

Rio Grande: 123.

Riviere a Jacques: 49.

Riviere Croche: $4^{8}$.

Riviere des Soldats: 45 .

Riviere du Chambly, Quebes: 34 .

Riviere du Chene: 77.

Riviere du Loup: 40.

Riviere du Sauteux: 104.

Robidou, François: meets expedition, 34; mentioned, 88, 138; sketch of, 147 .

Robidou, Joseph, Sr.: 147.

Robidou, Joseph, Jr.: 147.

Robidou family: 147 .

Robidoux, Louis R.: 147.

Robidoux, Sellico: 147.

Robinson, Dr. Doane: quoted, 67 , 68.

Rondin: 154 .

Rodriguez, Marie Ignacia: 142.

Roger Creek: 44 .

Rolette, dit Laderoute: II4.

Rolette, dit Laderoute, Catherine: 147.

Roman Nose, Sioux chief: see Nez de Corbeau.

Rose, Edouard: 157. 
Rosebud Creek: 56.

Rosebud Landing, S. D.: 56.

Ross, Alexander: cited, ro6.

Roture, Joseph: 156.

Rousseau, Michel: 157.

Routier, Genevieve: 148.

Roy, François: 157.

Roy, Madeleine: 156.

Ruff, Anne Elizabeth: 153.

Ruff, General Charles: 153.

Sacajawea: see Sakakawea.

Sage, Rufus: 140.

St. Charles County: 60,64 , 102, 146,154 ; records of, 13 .

St. Charles County Rangers: 35 .

S t. Charles, Mo.: described, 28; mentioned, 27, 60, 91, 114,153 .

St. Clair County, Ill.: court records, 154 .

St. Ferdinand Township: $138,146$.

Ste. Genevieve: Mo. 43.

St. Germain, Andre: 157 .

St. Helena, Neb.: 45 .

St. John's Township, Mo.: 144.

St. Joseph, Mo.: 88, 147, 155.

St. Louis Catholic Cathedral: records, 29, 154.

St. Louis, Mo.: court records, 13, 43, 59; mentioned, 17, 19, 53, 64, 114, 133,134,135, 139, 140, 142, 145, 147, 149, 156; boat, leaves for, 75 ; ex sedition leaves 27,33 ; directory of, 91, 155 .

St. Louis Missouri Fur Company: $15,43,111,148,150,151$.

St. Michel, Jean Baptiste: 60.

St. Peter's River: 90, 122.

St. Pierre, Gueniche: 158.

St. Rose, Quebec: 34.

Sakakawea: wife of Toussaint Charbonneau, 24; death of, 106; sketch of, 132; mentioned, 138, 140; monuments to, 135 .

Sal ine County, Mo.: 32.

Salt River: fort on, 123.

San Domingo: 153.

San Francisco: 35 .

Sanguinet, Charles, fils: in search of Champlain's party, 20, 76,
142, 158; makes signal fires, 54 ; sends letter to Lisa, IOI; asks for men to meet him, I03; no news from, 107; arrives at Fort, Iro; goes hunting, Ir6; helps Arikaras move, I17; goes to Mandans, I19; engage, 157; sketch of, 149.

Sanguinet, Christopher: 149.

Sanguinet, Simon: 149.

Sanguinet family: 150 .

Sanguinet \& Robidou: 149.

Sans Arcs Indians: 57.

Santa Fe, N. M.: 36, 23.

Santa Fe party: 17; at Fort Osage, 35 ; traders, 5 I.

Saone Indians: 56; described, 57; peace conference with Arikaras, 79; at Arikara village, 97; at Cheyenne camp, i24.

Sarpy County, Neb.: 44.

Sauk Indians: 27, 37, 148.

Sawyer: 39.

Say, Thomas: 44 .

Scalp Song: 104.

Schaeffer, Augustus: 155.

Schultz, James: cited, 133.

Selkirk Establishment: 24.

Senecal: ro3.

Shai-ene (Sioux name for Cheyenne Indians), 70.

Shannon, George: 56.

Shannon Creek: 56 .

Shawnee Indians: 52.

Sheheke (Big White), Mandan chief: 57 ; sketch of, 73 ; deat 2 of, 82 ; mentioned, 79,83 .

Shepherd River: 29.

Shope's: I31.

Shoshone Mountains: 77.

Shoshoni Indians: mentioned, 79, 101, 135, 138; described, 106.

Siblev, Major George C., Indian Agent: mentioned, 19, 34; describes Kansas Indians, 36 .

Sibley, Mo.: 34 .

Sihasapa Indians: 57 .

Simoneau Island: 156.

Simpson, Dr. Robert: 131 .

Sioux Indians: kill Lisa's men, 15 ; 
in War of $1812,22,55$; tradinghouse of, 28; mentioned, $50,5 \mathrm{I}$, 55,70 , 109; territory of, $5 \mathrm{I}$; at war with Poncas, $5 \mathbf{I}$; lodges of, 54, 104; at war with Arikaras, 76, 120; chiefs, 56, 77, 80; offer to make peace with Arikaras, 79; at Fort Manuel, 80, 82, 90; steal horses from Fort, 83 ; reportcd to have killed Bijou, 104, 105; reject Lisa's friendship, 108; Cheyennes offer peace pipe, I13; fight Cheyennes, I I 5 ; commence war on Arikaras, I13; chief killed, I I 5; attack Fort Manuel, 125, 127; steal Cheyennes' horses, I27; kill Grosventre Indian, 118.

Sioux City, Iowa: $45,47$.

Sire, Joseph A.: 156, 157.

Sleeper, Teton Sioux chief: sketch of, 55 .

Sleepy Eyes, Sioux chief: 56 .

Snake Indians: see Shoshoni Indians.

Snake River: 38.

Sni-a-bar Township, Jackson Co., Mo.: 33 .

Soldier River: described, 45 .

South Dakota Historical Society: 68.

Southwestern Historical Quarterly: 143.

Spanish Company: 60, I14, 149.

Spanish Country: 14 .

Spanish Military Post: 27.

Spanish settlements: 18 .

Spanish Traders: 16.

Spanish Waters: see Arkansas River.

Springfield, Ill.: 146.

Standing Rock Indian Reservation: 66.

Stanley County, S. D.: 63.

Stevens, Elisha, party: 35 .

Stoddard County, Mo.: 52.

Sun Island: $4 \mathrm{I}$.

Sun River (Perry Creek): 47.

Superintendent of Indian Affairs: $53,139$.
Sur-wa-carna (Park River): $6_{4}$.

Tabeau, Celeste: 88 .

Tabeau, Jacques: 88 .

Tabeau family: 88 .

Tanguay, L'Abbé Cyprien: cited, $42,89,124$.

Tapage, or Noisy Pawnee Indians : 60.

Tardit, G:uiommc: 157.

Taylor, Major Zachary: 35 .

Trhanka:ndala: 48.

Teton River (Bad River): mentioned, $52,56,57,58$; described, 62.

Teton Sioux Indians: mentioned, 55, 56; described, 57 .

Third Missouri Infantry, C. S. A.: 153.

Thompson, David: 79.

Three Forks, Mont.: 135 .

Ticio, Baptiste: 148.

Tillier, Rudolph, U. S. Indian Factor: 27.

Toulouse, Alexander: 158.

Tracy, Edward N.: 53.

Trail Creek: 153 .

Tripp County, S. D.: 54 .

Trudal, Françoise: 88.

Trudeau, Adrienne: 156.

Trudeau, Antoine L.: 156.

Trudeau, Jean Baptiste: 53, 60, $67,1_{14}, 156$.

Trudeau, Louis: 156.

Trudeau, Zenon: 103.

Tsis-tsis (Cheyenne): 70.

Two Forks: 135 .

Two Kettle Indians: 57.

Upper Missouri Outfit: 148, 155.

U. S. Geological Survey: 135 .

U. S. Indian Factory: 27.

U. S. Military Fort: 27 .

Ute Indians: ror.

Valle, Jean Baptiste: I44.

Vasquez \& Pratte: 148.

Vasseur, Helene: 34 .

Vasseur, Joseph: 34 .

Vera Cruz: 146. 
Verdigris River: 50.

Vermillion Post: 49.

Vermillion, S. D.: 48.

Vermillion River: 48, 51 .

Vernon County, Mo.: 5 I.

Vertefeuille, Joseph: I40.

Vertefeuille, Victoire: ${ }^{4} 40$.

Vincennes, Ind.: 146.

Wabash River: 50.

Wah-kan-tah-pay, Indian chief:

Wakpa Chicha (Bad River): 62.

Wallis, Allen: 88.

Wallis, Maryanne: 88.

War of 1812: 14, 22, 30, 34, 55, 57, 146.

Washington County, Mo.: 139.

Washington County, Neb.: 44, 45 .

Washte Wajpa (Good River): 63.

Wasiska: 53 .

Wassisha: 48.

Watpa-ipak-shan: 48.

Waugh, James C.: 53 .

Wayne County, Ky.: $3 \mathrm{I}$.

Weir, James: 65.

Weir, John: 65.

Weir, William: sketch $0^{\circ}, 65$; engagé, I 57 .

Welch, Rev. J. F.: 134 .

Wells County, N. D.: 49.

Westport, Mo.: I40.

Weterhoo (Grand River): 65.

Wheeler, O. D.: cited, 62, 137.
White Lime Creek: 53.

White Paint Creek: 53 .

White River: 14, 57, I40; described, 55 .

Whitestone River: 48.

Wihethtanga, Osage Indian woman: 60 .

Wilkinson, General James: 27.

Williams, Ezekiel: adventures of, 17-19; goes back to Arapaho village, 20; prisoner in Kansas village, $19,3.5$.

Wilt, Catherine: 153 .

Wilt, Christian: letter-book of, 12, I3, I5; letters to Luttig, 129131.

Wind River Mountains: 77.

Winnebago Indians: 51 .

Winnebago Land Company: 146.

Wiser, Peter: 102.

Woahl, François: see Oulle.

Wolf River: 40.

Wyeth, Nathaniel: 140.

Yankton Indians: described, 5I; mentioned, 55,56 .

Yankton, S. D.: 49.

Yanktonai Indians: $5 \mathrm{I}$; mentioned, 55, 72, I39; arrive at Fort, 8I.

Yellowstone River: 77.

York (Toronto), Canada: 123.

Zimm, Bruno Louis: 135 . 


\section{MISSOURI HISTORICAL SOCIETY PUBLICATIONS FOR SALE}

Vol. I., No. I-The Campaign of Missouri and Battle of Wilson's Creek, Co!. William M. Wherry, r880.*

Vol. I., No. 2-Recollections of Septuagenarian, Wm. Waldo, I880.*

Vol. I., No. 3-Archæological Explorations in Cole County, Mo.Dr. N. DeWyl; Prehistoric Remains in MissouriProf. G. C. Broadhead, 1880.*

Vol. I., No. 4-Amended Charter and By-Laws, 1880. \$0.25.

Vol. I., No. 5-Samuel Gaty of St. Louis-Darby \& Todd, I88r. $\$ 1.00$.

Vol. I., No. 6-Archæology of Missouri-Hilder.*

Vol. I., No. 7-President's Annual Address-Leighton, r883. \$1.00.

Vol. I., No. 8-Historical Societies in their Relation to Local Historical Interest-C. F. Robertson, 1883.*

Vol. I., No. 9-American Revolution and Acquisition of Mississippi Valley-C. F. Robertson, 1884. \$1.00.

Vol. I., No. Io-Attempts to Separate the West from the American Union-Robertson.*

Vol. I., No. I I-President's Address-Constitution and By-Laws and Members, I894. \$1.00.

Vol. I., No. I2-Newspapers and Newspaper People, by Wm. Hyde; Territoria! Revenue System of Missouri-Prof. Fredk. C. Hicks, I896. \$1.00.

Vol. I., No. 13-Boundaries of Louisiana Purchase-James O. Broadhead. \$r.oo.

Vol. I., No. 14-Catholic Church of St. Louis-The Beginnings of Ecclesiastical Jurisdiction in the Archdiocese Conway, 1897. \$1.00.

Vol. I., No. 15-Historical Loan Exhibit Report-Constitution and By-Laws, 1899.*

Vol. II., No. I-Missouri Historical Society Collections, January, I900.*

Vol. II., No. I-The Mound-Building Age in North America-Peterson, 1902. \$1.50.

Vol. II., No. 2-Missouri Historical Society Collections, April, 1903.*

Vol. II., No. 3-Personal Records of General Grant-Wm. Tausig, 1903.*

Vol. II., No. 4-A History of Battery A-Porter, 1904. \$1.50.

Vol. II., No. 5-The Montezuma Mounds-Gerard Fowke, 1905.*

*Out of print; of some of the others very few copies remain. 
Vol. II., No. 6-Missouri Historical Society Collections, July, 1906. $\$ 1.50$.

Vol. II., No. 7-Missouri Historical Society Collections, October, 1906. \$1.50.

Vol. III.-Four numbers.

Vol. IV.-Three numbers. No. 4 to be published soon.

Vols. III. and IV., $\$ 1.50$ per number, or $\$ 5.00$ per volume.

Bulletin I.-Prehistoric Objects Classified and Described-Gerard Fowke. \$o.25.

\section{BOOKS}

A Journey to the Rocky Mountains in the Year 1839 , by F. A. Wislizenus, M.D. Translated from the German, with a sketch of the author's life, by Frederick A. Wislizenus, Esq. St. Louis. Missouri Historical Society, 1912. $162 \mathrm{pp}$. Frontispiece portrait and map. 8vo. \$4.00.

Official Report of the Universal Congress of Lawyers and Jurists. Held at St. Louis, Missouri, U. S. A., September 28, 29 and 30, 1904, under the auspices of the Universal Exposition and American Bar Association. Edited by the Secretary of the Congress. St. Louis. Published by the Executive Committee, 1905. 423 pp. 8vo. 16 copies only. \$2.00, net.

Universal Exposition of 1904, by David R. Francis. 2 vols. St. Louis. Louisiana Purchase Exposition Company, 1913. Roy. 8vo. 1133 pp., with several hundred illustrations. 250 copies. $\$ 5.00$, net.

Three Years Among the Indians and Mexicans, by Thomas James. Edited with notes and biographical sketches by Walter B. Douglas. St. Louis. Missouri Historical Society, 1916. 316 pp. Portraits and map. 8vo. \$\$6.00, net. 



\section{.}



.

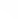


HD

9944

U46M8
Luttig, John C

Journal of a fur-trading expedition

\section{PLEASE DO NOT REMOVE CARDS OR SLIPS FROM THIS POCKET}

\section{UNIVERSITY OF TORONTO LIBRARY}




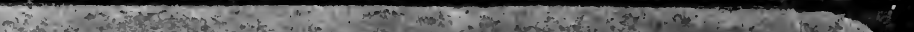

.

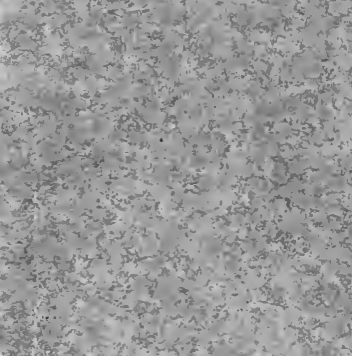

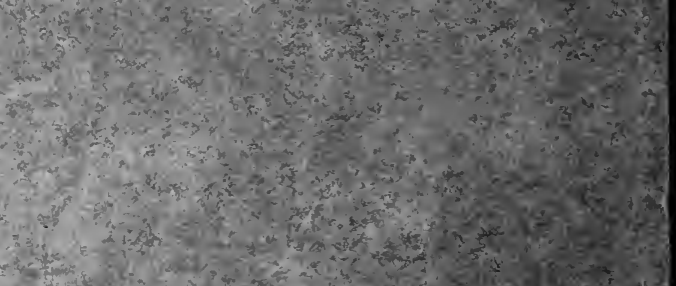

as

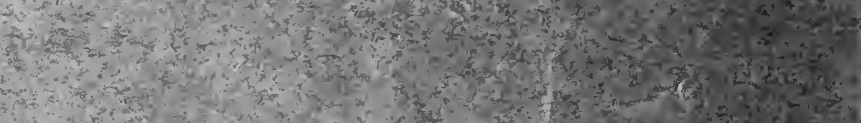

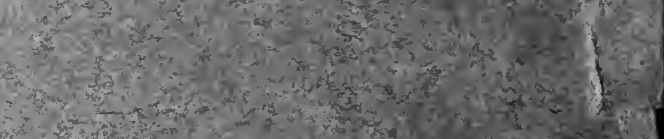

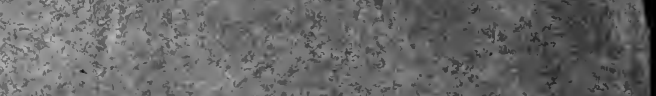

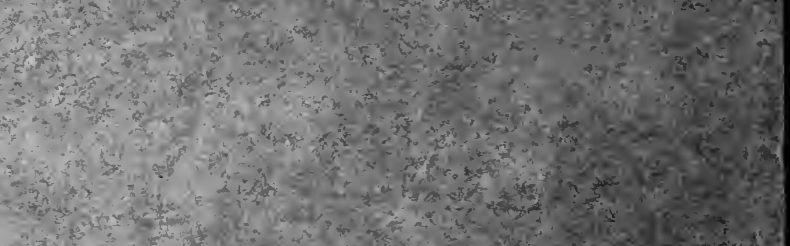

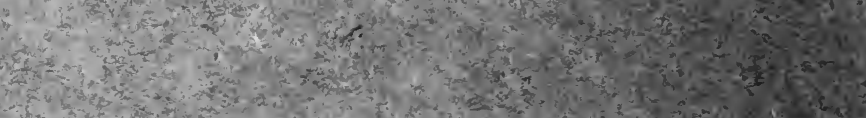

